\author{
Mon og r a p h \\ urn:lsid:zoobank.org:pub:79BE13FC-B840-4C39-8D25-3328BDCC44D2
}

\title{
Revision of Chondrocyclus s.l. (Mollusca: Cyclophoridae), with description of a new genus and twelve new species
}

\author{
Mary L. COLE \\ East London Museum, P.O. Box 11021, Southernwood, 5213, \\ South Africa and Department of Zoology and Entomology, Rhodes University, \\ P.O. Box 94, Grahamstown (Makhanda) 6140, South Africa. \\ E-mail: marybursey@elmuseum.za.org \\ urn:lsid:zoobank.org:author:FDA80F4A-4E08-401E-8FF6-778E033BBBA7
}

\begin{abstract}
Chondrocyclus Ancey, 1898 is a genus of nine species of African operculate land snails restricted to indigenous forest and mesic thicket. Worn specimens (i.e., without a periostracum or operculum), on which some species descriptions and records were based, appear to be indistinguishable morphologically. A comprehensive revision of Chondrocyclus s.l. is provided here based on comparative morphological examinations of the shell, protoconch, periostracum, operculum, radula and penis, and on mitochondrial genes cytochrome c oxidase subunit I and 16S rRNA. Two genus-level lineages are recognised, Chondrocyclus s.s. and Afrocyclus gen. nov. Revised species descriptions are given for seven species. Two species, C. meredithae Bruggen, 1983 and C. chirindae Bruggen, 1986 both from north of South Africa, are removed from Chondrocyclus. Twelve new species are described: C. herberti sp. nov., C. silvicolus sp. nov., C. amathole sp. nov., C. pondoensis sp. nov., C. devilliersi sp. nov., C. pulcherrimus sp. nov., C. cooperae sp. nov., $C$. langebergensis sp. nov., $C$. kevincolei sp. nov., A. oxygala gen. et sp. nov., A. potteri gen. et sp. nov. and $A$. bhaca gen. et sp. nov. This is the first detailed systematic revision of an Afrotropical cyclophorid group to include morphological and molecular data. This study complements research on other taxa of low-vagility forest-dwelling habitat specialists by providing comparative distribution data for an independent, widespread group. Such evidence is urgently needed for conservation of South Africa's threatened forest biome.
\end{abstract}

Keywords. Cyclophoroidea, new genus, systematics, South African distribution, forests.

Cole M.L. 2019. Revision of Chondrocyclus s.l. (Mollusca: Cyclophoridae), with description of a new genus and twelve new species. European Journal of Taxonomy 569: 1-92. https://doi.org/10.5852/ejt.2019.569

\section{Introduction}

The genus Chondrocyclus was created by Ancey (1898) for operculate snails "from the Cape of Good Hope, remarkable by the nature of its periostracum, its depressed shape, its thin peristome and its small size." The genus was last reviewed in 1939 (Connolly 1939) and contained seven species, all endemic to South Africa. Subsequently, two small cyclophorids Chondrocyclus meredithae Bruggen, 1983 and C. chirindae Bruggen, 1986 were described from Malawi and Zimbabwe respectively, but morphological data suggested that they should be removed from the genus (Cole et al. 2019). Three 
Madagascan cyclophorids were also classified in Chondrocyclus (Fischer-Piette et al. 1993), but these have been reassigned to three other genera (Emberton 2004).

The first molecular systematic study of an Afrotropical cyclophorid group presented a molecular phylogeny of Chondrocyclus s.l. (Fig. 1), and assessed the taxonomic value of a range of morphological characters, using fresh material and museum specimens from across the known range of the genus (Cole et al. 2019). Concordance of molecular and morphological data confirmed the taxonomic status of the seven South African species and provided evidence for the existence of at least twelve undescribed species (Cole et al. 2019). These data show that Chondrocyclus s.l. underwent at least two major

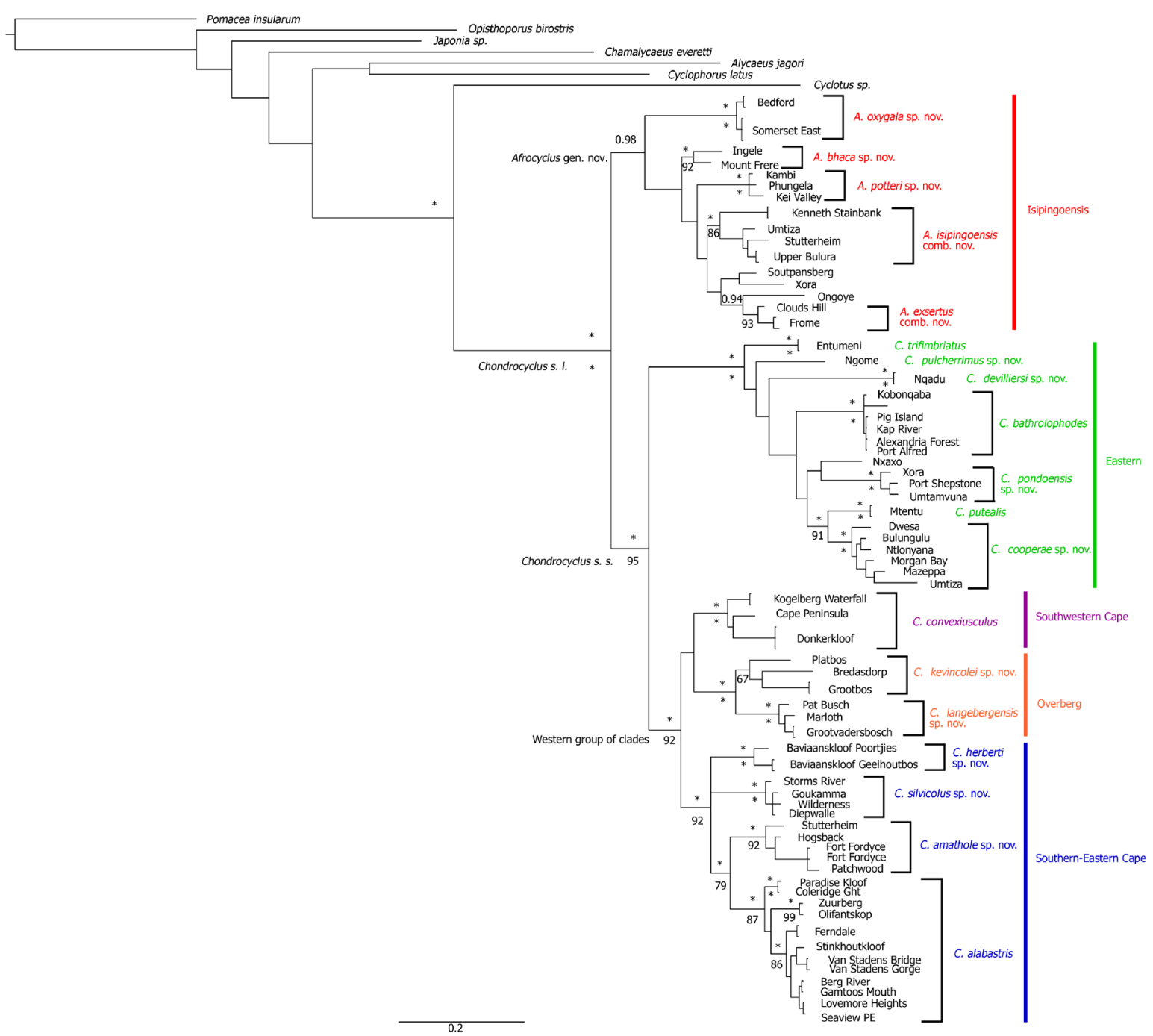

Fig. 1. Bayesian Inference majority consensus tree of the "taxa complete" concatenated CO1-16S sequence dataset for Chondrocyclus s.l. Ancey, 1898 (84 sequences) and seven other caenogastropods with the tree rooted on Pomacea insularum (d'Orbigny, 1837) (modified from Cole et al. 2019). Colours indicate major clades of Chondrocyclus Ancey, 1898 and correspond with colours used in maps. Support values are given as posterior probabilities for Bayesian analysis above nodes (only values $\geq 0.95$ are shown) and as bootstrap percentages for ML analysis below nodes (only values $\geq 65 \%$ are shown); maximal support (Bayesian $=1, \mathrm{ML}=100 \%)$ is indicated by an asterisk. Scale bar indicates substitutions per site. 
radiations, one mainly Afromontane and the other largely coastal. Chondrocyclus s.s. contained four major clades distributed coastwards of the Great Escarpment, between the Cape Peninsula and northern KwaZulu-Natal (Fig. 2). This radiation showed a primary dichotomy into an Eastern clade and a western group of three clades (Southwestern Cape, Overberg and Southern-Eastern Cape), in the region of the country where a transition between subtropical and temperate influences is well documented across other faunal and floral taxa (e.g., Branch \& Branch 1981; Cowling \& Pierce 2009). The other lineage was even more widely distributed in latitude and altitude, occupying isolated Afromontane forest patches along the Great Escarpment from northern South Africa (Limpopo province, $23^{\circ} \mathrm{S}$ ) to the Eastern Cape and extending to the coast (Fig. 2). This lineage is recognised herein as a separate genus, Afrocyclus gen. nov., which requires further molecular and morphological data from throughout its range to unravel its systematics.

Cyclophoridae in the Afrotropical region, although not comparable in species and genus-level diversity to the Asian tropics, is taxonomically diverse and includes a few species-rich groups in Madagascar (Emberton 2002a, 2003, 2009; Emberton \& Pearce 1999; Emberton et al. 2010). In mainland Africa, cyclophorids are widely distributed, and currently 20 species are recognised in three genera: Chondrocyclus (seven species in South Africa, one species in Zimbabwe and one in Malawi), Cyathopoma W. \& H. Blanford, 1861 (nine species across East, Central and West Africa) and Elgonocyclus Verdcourt, 1982 (one species in East and Central Africa and one undescribed species in South Africa). Historically, South African Cyclophoridae were assigned to various genera (Pfeiffer 1855; Craven 1880; Sturany 1898; Kobelt 1902).

The taxonomy of some cyclophoroidean taxa is in a state of flux, including the family placement of Chondrocyclus. The Cyclophoridae Gray, 1847 was considered to be the most speciose

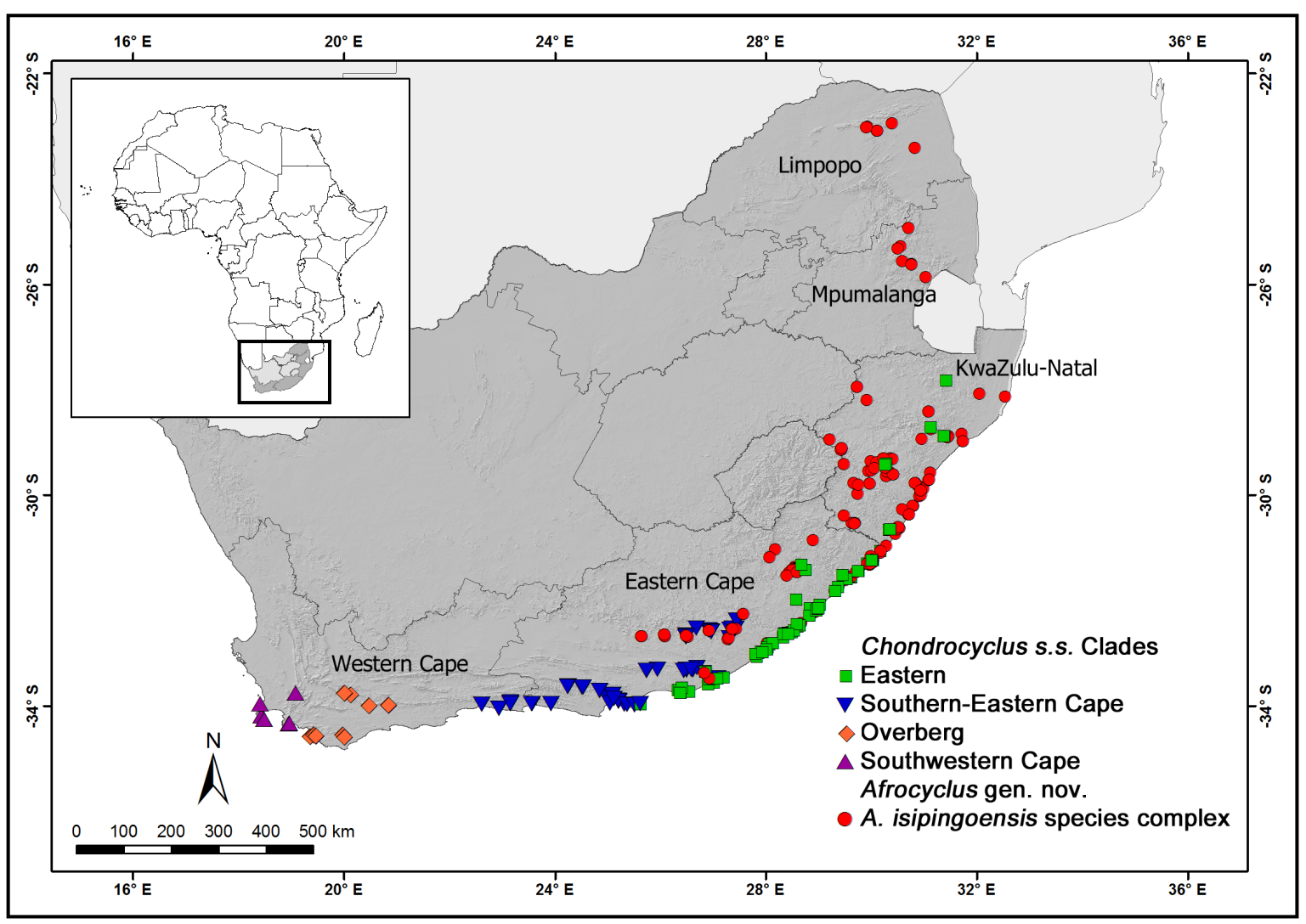

Fig. 2. Map of South Africa showing distribution of the five major clades of Chondrocyclus s.1. Ancey, 1898. Provinces with records of Chondrocyclus are labelled. 
family of operculate, terrestrial molluscs, containing approximately 35 genera and 810 species (Nantarat et al. 2014a). However, a recent classification placed Chondrocyclus as well as various Madagascan 'cyclophorids', including Acroptychia Crosse \& P. Fischer, 1877, in the Megalomastomatidae Blanford, 1864 (Bank 2017, unpublished, see MolluscaBase (2019) http://www.molluscabase.org/aphia.php?p=taxdetails\&id=995565; accessed 26 Apr. 2019). This was probably based on the study of Webster et al. (2012) which was the first showing phylogenetic relationships between various cyclophoroidean families, in spite of the conclusion of Bouchet et al. (2017) that the limited taxon sampling in Webster et al. (2012) did not allow a re-evaluation of the classification of Cyclophoridae. Webster et al. (2012) considered the Madagascan Acroptychia as representative of the Megalomastomatidae (which they incorrectly called Megalostomatidae), sister to Cochlostomatidae Kobelt, 1902. However, instead of elevating Cochlostomatinae Kobelt, 1902 to family status and recognising three families (Cyclophoridae, Megalomastomatidae and Cochlostomatidae) in a very wellsupported clade (Webster et al. 2012: fig. 3), this clade could be considered to represent Cyclophoridae alone (with three subfamilies). Chondrocyclus s.l. is maintained in the family Cyclophoridae because there does not appear to be any justification for moving it to the Megalomastomatidae. The latter is a taxon based on the Caribbean genus Megalomastoma Swainson, 1840, and in the opinion of the author Chondrocyclus and the other Madagascan 'cyclophorids' which were moved to Megalomastomatidae, are more likely to have affinities with true cyclophorids from India and southeast Asia, than with Caribbean taxa. The clustering of Chondrocyclus as sister to Cyclotus Guilding in Swainson, 1840 (Fig. 1), which both Webster et al. (2012) and MolluscaBase (2019) consider to be in Cyclophoridae, supports its placement.

Snails of Chondrocyclus are restricted to indigenous forest and mesic thicket, both highly fragmented vegetation types. Their range extends over $2000 \mathrm{~km}$ along the South African coastal plateau and Great Escarpment, a pattern mirrored by several other molluscan genera endemic or nearly endemic to South Africa (e.g., Fauxulus Schaufuss, 1869, Gittenedouardia Bank \& Menkhorst, 2008, Nata Watson, 1934, Natalina Pilsbry, 1893, Sheldonia s.l. Ancey, 1887) (Bruggen 1978). It is suggested that the majority of southern African terrestrial mollusc groups had their origin in tropical Africa, migrated southwards and radiated in the south (Bruggen 1978) although there are no phylogeographic studies to test this hypothesis. Some species of Chondrocyclus may be locally abundant and are amongst the most frequently encountered terrestrial snails while others are patchily distributed within a given forest and apparently rare. They crawl on dead leaves during damp conditions. Hairs and periostracal flanges are observed in unrelated taxa of snails living in moist microhabitats and are suggested to increase adhesion to wet surfaces during foraging by arboreal snails (Pfenninger et al. 2005). The advantage of these energetically costly structures in litter-dwelling snails has not been investigated. Details of diet are not recorded (Herbert \& Kilburn 2004), but they are likely to feed on detritus, bacterial films, fungi and lichens, contributing to nutrient recycling. During dry conditions they withdraw into the shell and seal off the aperture with the operculum, an effective barrier to desiccation.

Shells of Chondrocyclus s.1. Ancey, 1898 are characterised by their small size (3-7 mm diameter), lenticular to discoidal shape, circular and detached peristome, large umbilicus and, in fresh specimens, an elaborate periostracum and operculum. A few other South African taxa (Trachycystis spp.) bear convergent periostracal protuberances, but Chondrocyclus s.l. are readily distinguished by the possession of an operculum. However, worn specimens (i.e., without a periostracum or operculum), on which some species descriptions and records were based, appear to be indistinguishable morphologically at an interspecific level, and this has created much taxonomic confusion (Connolly 1939; Herbert \& Kilburn 2004). Apart from details on the radulae of a few species (Connolly 1939), data are scarce on the internal anatomy (e.g., genitalia) and external morphology of Chondrocyclus. 
Combining molecular data with detailed morphological examinations of the shell, protoconch, periostracum, operculum, radula and penis, the species-level taxonomy of Chondrocyclus s.s. is updated and a comprehensive revision of all species is provided, including keys. Afrocyclus isipingoensis (Sturany, 1898) gen. et comb. nov., A. exsertus (Melvill \& Ponsonby, 1903) gen. et comb. nov. and three undescribed species of Afrocyclus gen. nov. are also treated. The generic placement of the two species from north of South Africa is discussed in relation to other African cyclophorid genera.

\section{Material and methods}

Detailed morphological examinations of the shell, protoconch, periostracum, operculum, radula and penis of fresh material and museum specimens from populations throughout South Africa, including all nominal South African species, were undertaken. Material examined is housed mainly in two South African museums, the East London Museum (ELM) and the KwaZulu-Natal Museum (NMSA). Most of this material has been accumulated by field surveys undertaken since the mid-1990s by D. Herbert and the author, assisted by staff of the ELM and NMSA. Fresh specimens of Chondrocyclus meredithae Bruggen, 1983 and Chondrocyclus chirindae Bruggen, 1986 could not be obtained, but the shell and operculum of one specimen of each species were examined (ELMD 18072 and NMSA L4904, respectively), as well as photographs of a paratype of C. meredithae (NHMUK 198338). Types in The Natural History Museum, London (NHM) and specimens in the National Museum of Natural History, Leiden (RMNH) were examined. Fresh specimens were donated to the NHM, RMHN and the National Museum of Wales, Cardiff (NMW).

For the anatomical study, living adult specimens were drowned in sealed containers and preserved in $70 \%$ ethanol for dissection. Cleaning and dissections were performed under a Euromex dissecting microscope. Shells and opercula were cleaned in an ultrasonic bath and then manually under the dissecting microscope to remove caked soil from within the delicate ornamentation of both structures. Radulae were extracted by maceration of the body anterior in dilute $\mathrm{NaOH}$ and the radula teased out from the surrounding tissue, and rinsed in distilled water. The radula was then placed in a drop of ethanol on a stub with double-sided carbon tape and manouvered into position as the ethanol dried. The teeth at the outer edge of each row were folded outwards to expose the seven teeth per row. Penes were prepared for examination by cutting away the mantle tissue to expose the penis where it lies on the dorsal surface behind the right tentacle. Samples were dehydrated by placing in a series of ethanol of increasing concentration, and dried in a Polaron Critical Point Drier.

Shells, opercula, radulae and penes for Scanning Electron Microscope examination were coated with gold-palladium and examined at 5-20 kv accelerating voltage in a Tescan Vega SEM. Colour photographs of NHM types were supplied by the NHM. Photographs of holotypes were taken using a Zeiss Stemi 2000-C dissecting microscope with AxioCam ERc5s digital camera and stacked images were then combined using Helicon Focus Pro (Helicon Soft Ltd) to provide extended depth of field. Figure 8 was taken using an Olympus SZX 16 microscope with the AnalySIS programme.

Shell diameter at widest point (D) and height $(\mathrm{H})$ measurements were made with the shell held in apertural view with the axis of coiling vertical, using an eyepiece graticule. Shell diameter:height ratios (D:H) were calculated. The number of lamellate axial costae on the last whorl were counted. Immature shells (peristome not detached from last whorl) were excluded from the data used to calculate D:H ratios and densities of lamellate costae. The number of protoconch whorls were counted as shown in Fig. 3 although the precise number was often difficult to determine.

Systematic descriptions are provided for all taxa identified during this study. Type material is listed with redescriptions and descriptions. 


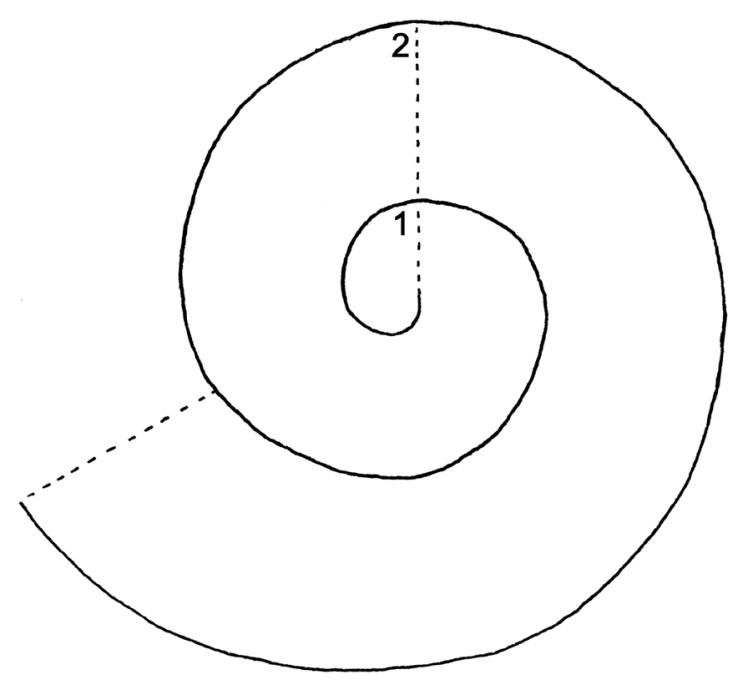

Fig. 3. Diagram illustrating method for measuring protoconch whorls.

Vegetation classification follows von Maltitz et al. (2003), Mucina \& Geldenhuys (2006) and Mucina et al. (2007) for true forests, and chapters in Mucina \& Rutherford (2006) for Albany Thicket and other vegetation types.

Methods used in laboratory procedures for obtaining molecular data and in phylogenetic analyses are described in Cole et al. (2019).
Abbreviations:
ELM = East London Museum, East London, South Africa
NMSA $=$ KwaZulu-Natal Museum, Pietermaritzburg, South Africa
NHMUK $=$ The Natural History Museum, London, United Kingdom
NMW = National Museum of Wales, Cardiff, Wales, United Kingdom
RMNH = National Museum of Natural History, Leiden, The Netherlands

\section{Results}

\section{Comparative morphological observations}

Variability of morphological characters between taxa is illustrated in Cole et al. (2019; Figs 9-10) and summarised below, and those characters considered to delineate the nominal and new species of Chondrocyclus s.l. were tabulated in supplementary table S2 in Cole et al. (2019). The periostracum had distinctive types of expansions of the axial costae and varying numbers of spiral rows of these structures. Two clades had hairs/bristles in multiple spiral rows (Isipingoensis and Overberg clades). There was only one row of flanges around the periphery in the Southwestern Cape and Southern-Eastern Cape clades; these flanges were typically pointed, but rounded in one taxon in the latter clade. The Eastern clade had rounded flanges, one row at the periphery and additional spiral rows on either side of this in the majority of taxa. The shell was smooth once the periostracum was removed and there were no spiral keels on the shell, but spiral grooves may occur. The protoconch was mammillate in the majority of clades, but flat in the Eastern clade, and the degree of malleation varied. The operculum was chitinous (corneous), with no calcification, and duplex, consisting of a translucent, thin, smooth inner portion, and an outer portion formed by an erect spiral lamella which was elevated towards the outer whorls and bore a fringe reflexed over the peristome. The outer portion was shallowly concave in the majority of taxa, but deeply concave in three species in the Eastern clade. The radula was taenioglossate (central tooth flanked on either side 
by three laterals in each row), all with well-developed, sharp cusps. The central cusp of the rachidian tooth was usually approx. twice as long as the flanking cusps, but in two taxa in the Eastern clade all five cusps were uniform in size. There were either two or three large cusps on the second lateral tooth, consistent within a clade. The penis lay on the dorsal surface immediately behind the right tentacle, and consisted of a muscular shaft with annular rugae and a shorter, tapering intromittent organ without flagellum. The shaft was more or less cylindrical in most taxa, but dorso-ventrally flattened and laterally expanded towards the distal end in the Eastern clade.

Several characters closely resembled those features described in other cyclophorids or species in related families in Africa, Asia and New Zealand (e.g., Morton 1952; Bruggen 1983, 1985, 1986; Emberton 2003; Marshall \& Barker 2007; Lee et al. 2008a; Rowson et al. 2010b; Páll-Gergely et al. 2017b). These include multiple spiral rows of hairs on the periostracum, taenioglossate radula and numbers of cusps on teeth, mammillation of the protoconch, and penis position and shape.

\section{Systematic descriptions}

Class Gastropoda Cuvier, 1795

Subclass Caenogastropoda Cox, 1960

Order Architaenioglossa Haller, 1890

Superfamily Cyclophoroidea Gray, 1847

Family Cyclophoridae Gray, 1847

Genus Chondrocyclus sensu lato Ancey, 1898

Chondrocyclus Ancey, 1898: 136 (type species by original designation: Cyclostoma convexiusculum Pfeiffer, 1855).

Chondrocyclus - Kobelt 1902: 230. — Connolly 1929: 239; 1939: 536. — Herbert \& Kilburn 2004: 90

\section{Key to genera within Chondrocyclus s.l.}

1. Shell with axial periostracal costae usually expanded into spiral row(s) of broad-based flanges with pointed or rounded tips, radula with 2 or 3 large cusps on second lateral tooth, Cape peninsula to northern KwaZulu-Natal; or shell with axial periostracal costae expanded into spiral rows of hairs; operculum slightly concave, robust and dark brown, radula with 3 large cusps on second lateral tooth, Southwestern Cape only

Chondrocyclus s.s. Ancey, 1898

- Shell with axial periostracal costae usually expanded into spiral rows of hairs, operculum flat, very fragile and pale corneous honey-brown, radula with two large cusps on second lateral tooth, Afromontane and southeast coast; or shell with axial periostracal costae slightly expanded at periphery, but not produced into hairs, radula with two large cusps on second lateral tooth, operculum with fringe consisting of bunches of short bristles, KwaZulu-Natal south coast only

Afrocyclus gen. nov.

Genus Chondrocyclus sensu stricto Ancey, 1898

\section{Diagnosis}

Shell dextral, small ( 4.5-6.5 mm), depressed, lenticular; aperture circular, last whorl descending near aperture, peristome not thickened, continuous and free; umbilicus wide and deep, exposing all the whorls; periostracum glossy and lacquer-like with lamellate axial costae at regular intervals, expanded into spiral rows of hairs or flanges; operculum duplex, corneous; inner portion consists of a thin disc which grows outwards in a tight spiral, smooth on inside where it attaches to foot; fused to disc on its outer surface is a multispiral, elevated horny blade-like lamella formed by fused bristles; height of lamella 
increases as it spirals outwards forming a concave exterior element; lamella not vertical, but stepped or flared, so that diameter of each whorl larger at proximal edge of lamellar blade; a fringe of fused bristles emanates from outer surface of each lamellar whorl; fringe reflexed over peristome but operculum can be withdrawn into aperture; radula taenioglossate; penis lies dorsally immediately behind right tentacle and consists of a stout, muscular shaft, cylindrical or dorsoventrally flattened and wrinkled along most of its length due to annular rugae, and a terminal, tapering intromittent organ without flagellum; seminal tube completely enclosed without seminal groove.

\section{Key to species of Chondrocyclus}

1. Periostracum bears spiral rows of hairs arising from axial lamellae .............................................. 2

- Axial lamellae of periostracum expanded into pointed or rounded flanges ..................................... 3

2. Distinct spiral grooves on shell corresponding to rows of periostracal hairs ....C. kevincolei sp. nov.

- Spiral grooves weak if present .C. langebergensis sp. nov.

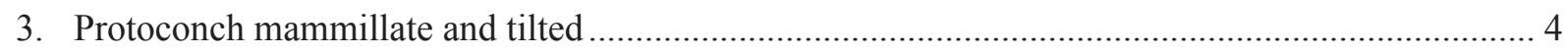

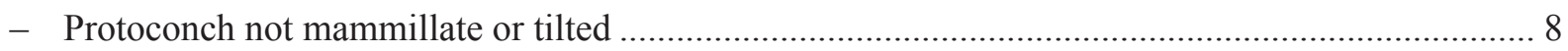

4. Axial lamellae expanded into broadly rounded flanges at periphery; lamellae with numerous ridges perpendicular to shell surface

C. amathole sp. nov.

- Periostracal flanges taper towards their proximal ends 5

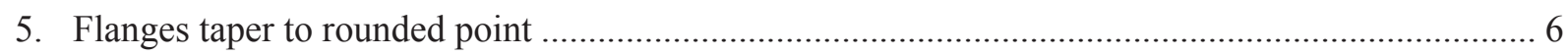

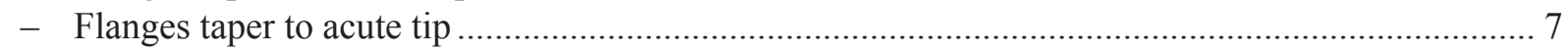

6. Axial lamellae widely spaced; approx. 45 on body whorl.

C. herberti sp. nov.

- Axial lamellae less widely space, approx. 70 on body whorl.

C. silvicolus sp. nov.

7. Flanges taper from broad base into a long spine; second lateral tooth of radula with three large cusps; Western Cape

C. convexiusculus (Pfeiffer, 1855)

- Flanges taper gradually towards tips; if spine-tipped, spine short; second lateral tooth of radula with two large cusps; Eastern Cape

C. alabastris (Craven, 1880)

8. Operculum deeply or shallowly cup-shaped in side view

- Operculum more or less flattened in side view with outer portion parallel to disc surface and appears attached to disc by pedestal

9. Body whorl with at least six spiral rows of broadly rounded flanges.

C. cooperae sp. nov.

- Body whorl with three spiral rows of broadly rounded flanges.

10. Operculum deeply cup-shaped; southern Kwazulu-Natal and northern Transkei

C. putealis Connolly, 1939

- Operculum cup-shaped; Albany area and southern Transkei .......C. bathrolophodes Connolly, 1929

11. Operculum with spiral lamella of outer portion raised above level of fringe in side view; southern KwaZulu-Natal and Transkei.

C. pondoensis sp. nov.

- Operculum with spiral lamella not raised above fringe.

12. Body whorl with only one row of broadly rounded flanges at periphery

C. devilliersi sp. nov.

- Body whorl with multiple spiral rows of rounded or paddle-shaped flanges 13

13. Body whorl with 12 spiral rows of flanges; spire almost flat

C. pulcherrimus sp. nov.

- Body whorl with five spiral rows of flanges. C. trifimbriatus Connolly, 1929 
COLE M.L., Revision of cyclophorid snails Chondrocyclus s.l.

Chondrocyclus convexiusculus (Pfeiffer, 1855)

Figs 4, 5, 8C

Cyclostoma (Cyclophorus) convexiusculum Pfeiffer, 1855: 104 (type loc.: Simonstown [Macgillivray]). Cyclophorus convexiusculus var. minor Benson, 1856: 438 (type loc.: Table Mountain [Layard]).

Chondrocyclus convexiusculus - Kobelt 1902: 230. — Connolly 1939: 536. — Herbert \& Kilburn 2004:

92.

\section{Diagnosis}

Shell small, depressed, lenticular; protoconch mammillate and tilted; periostracum with axial costae developing at the periphery broad triangular flanges each terminating in a long, hair-like spine; operculum flattened, exterior portion shallowly concave, with step-shaped multispiral lamella terminating in a long solid fringe; radula with three large cusps on second lateral tooth.

\section{Etymology}

The specific name is derived from the Latin 'convex', meaning 'arched or vaulted'.

\section{Type material examined}

\section{Syntypes}

SOUTH AFRICA - Western Cape - 3 specimens; syntypes of Cyclostoma (Cyclophorus) convexiusculum Pfeiffer, 1855 (Fig. 4A); Simons Bay; [Mrs] Cuming leg.; NHMUK 20120231.

\section{Other material examined}

SOUTH AFRICA - Western Cape $\bullet 6$ specimens; Cape Peninsula, Simonstown; $34.1912^{\circ} \mathrm{S}, 18.4211^{\circ} \mathrm{E}$; M. Connolly coll.; NMSA $2777 \bullet 2$ specimens; same collection data as for preceding; ex. M. Connolly coll.; NMSA A8004 • 11 specimens; Cape Town, 2.8 km south of Miller's Point, forest in a depression with a few invasive trees (Eucalyptus and Port Jackson), steep slope with rocks and root buttresses; $34.2507^{\circ} \mathrm{S}, 18.4729^{\circ} \mathrm{E} ; 25$ Jun. 2011; R. Daniels leg.; thick and moist leaf litter, about a week of rain before collection; ELM D16879 • 11 specimens; same collection data as for preceding; ELM W3636 • 1 specimen in ethanol; same collection data as for preceding; NHMUK 20120276 40 specimens; same collection data as for preceding; 1 Feb. 2012; R. Daniels leg.; ELM D16880 • 17 specimens; same collection data as for preceding; ELM W3637 - 3 specimens; same collection data as for preceding; NHMUK 20120277 • 2 specimens; same collection data as for preceding; NMW.Z.2012.065.00007 • 5 specimens; DuToits Kloof, Donkerkloof, patch of Southern Afrotemperate forest in steep ravine; 33.7536 S, $19.0696^{\circ}$ E; 462 m a.s.l.; 7 Aug. 2014; M. Cole leg.; ELM D17970 • 1 specimen; same collection data as for preceding; ELM W3891 • 26 specimens; Kogelberg Nature Reserve, small patch of Southern Afrotemperate forest near Leopards Gorge waterfall; $34.3409^{\circ} \mathrm{S}, 18.9407^{\circ} \mathrm{E} ; 312 \mathrm{~m}$ a.s.l.; 12 Aug. 2014; M. Cole leg.; ELM D17955 • 22 specimens; same collection data as for preceding; ELM W03876 - 22 specimens; Kogelberg Nature Reserve, Oudebosch, patch of Southern Afrotemperate forest in kloof with Oudebos River; $34.3337^{\circ} \mathrm{S}, 18.9487^{\circ} \mathrm{E}$; $260 \mathrm{~m}$ a.s.1.; 12 Aug. 2014; M. Cole leg.; ELM D17975 • 25 specimens; same collection data as for preceding; ELM W03877.

\section{Description}

SHELl (Fig. 4B-D). Small, depressed, lenticular, adult diameter 3.97-5.18 mm, height 2.29-3.20 mm, diameter:height 1.59-1.88 ( $\mathrm{n}=21)$. Spire little exserted, apex mammillate and tilted (Fig. 4A, C). Embryonic shell (Fig. 4E) approx. 2.25 whorls, microscopically malleate, sculpture strongest on earliest part, junction between embryonic shell and teleoconch evident with development of axial costae and threads on teleoconch. Teleoconch comprising 2.25 whorls, convex, rapidly increasing, suture deeply 


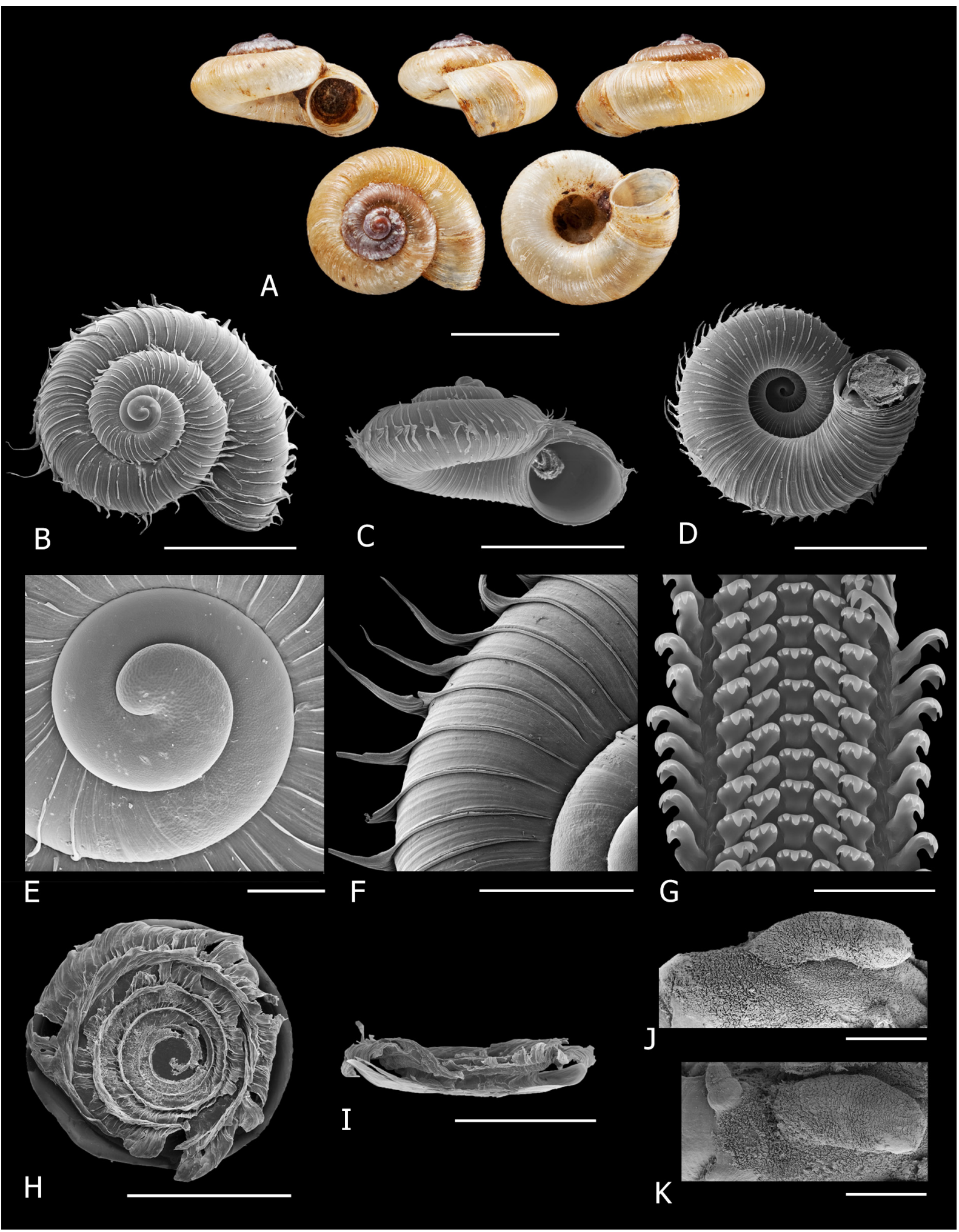

Fig. 4. Chondrocyclus convexiusculus (Pfeiffer, 1855). A. Syntype (NHMUK 20120231). B-K. ELM W3636. B. Dorsal view. C. Aperture view. D. Ventral view. E. Protoconch. F. Detail of axial lamellae of periostracum. G. Portion of radula. H-I. Operculum. J-K. Penis, lateral and dorsal views, showing position on head. Scale bars: A, C $=3 \mathrm{~mm} ; \mathrm{B}, \mathrm{D}=2 \mathrm{~mm} ; \mathrm{E}=200 \mu \mathrm{m} ; \mathrm{F}, \mathrm{J}-\mathrm{K}=500 \mu \mathrm{m} ; \mathrm{G}=50 \mu \mathrm{m}$; $\mathrm{H}-\mathrm{I}=1 \mathrm{~mm}$. 
impressed. Aperture circular, last whorl descending near aperture, peristome simple, continuous and free. Umbilicus wide and deep, exposing all the whorls. Periostracum glossy, honey-brown and lacquerlike with lamellate axial costae at regular intervals, 44-61 $(\mathrm{n}=16)$ on last whorl, developing at periphery broad triangular flanges terminating in a long, hair-like spine (Figs 4F, 8C); intervals between costae with 3-5 indistinct microscopic axial threads. Shell translucent glossy honey-brown or creamy-white when fresh.

Living ANIMAL. Head, tentacles and snout dark grey; underside of foot white.

OperCulum (Fig. 4H-I). Duplex, outer portion concave, consists of multispiral lamella with almost five whorls, each step-shaped; the growing edge of the lamellar blade angular and is more or less perpendicular to disc where it is attached; long fringe of fused bristles emanates from outer side of lamellar blade and curves upwards and outwards forming a furrow between fringe and lamellar blade partially covered by top edge of lamellar blade which curves outwards; top edge of lamella projects above fringe; fringe of each whorl fused to lamella of following whorl.

Radula (Fig. 4G). Rachidian with five cusps, central cusp approx. twice as long as two on either side of it; first and second lateral tooth each with four cusps and a swelling representing the fifth cusp, first three cusps (from centre) increasing in size and fourth considerably smaller.

Penis (Fig. 4J-K). Shaft more-or-less cyclindrical with slightly swollen distal end and a short intromittent organ.

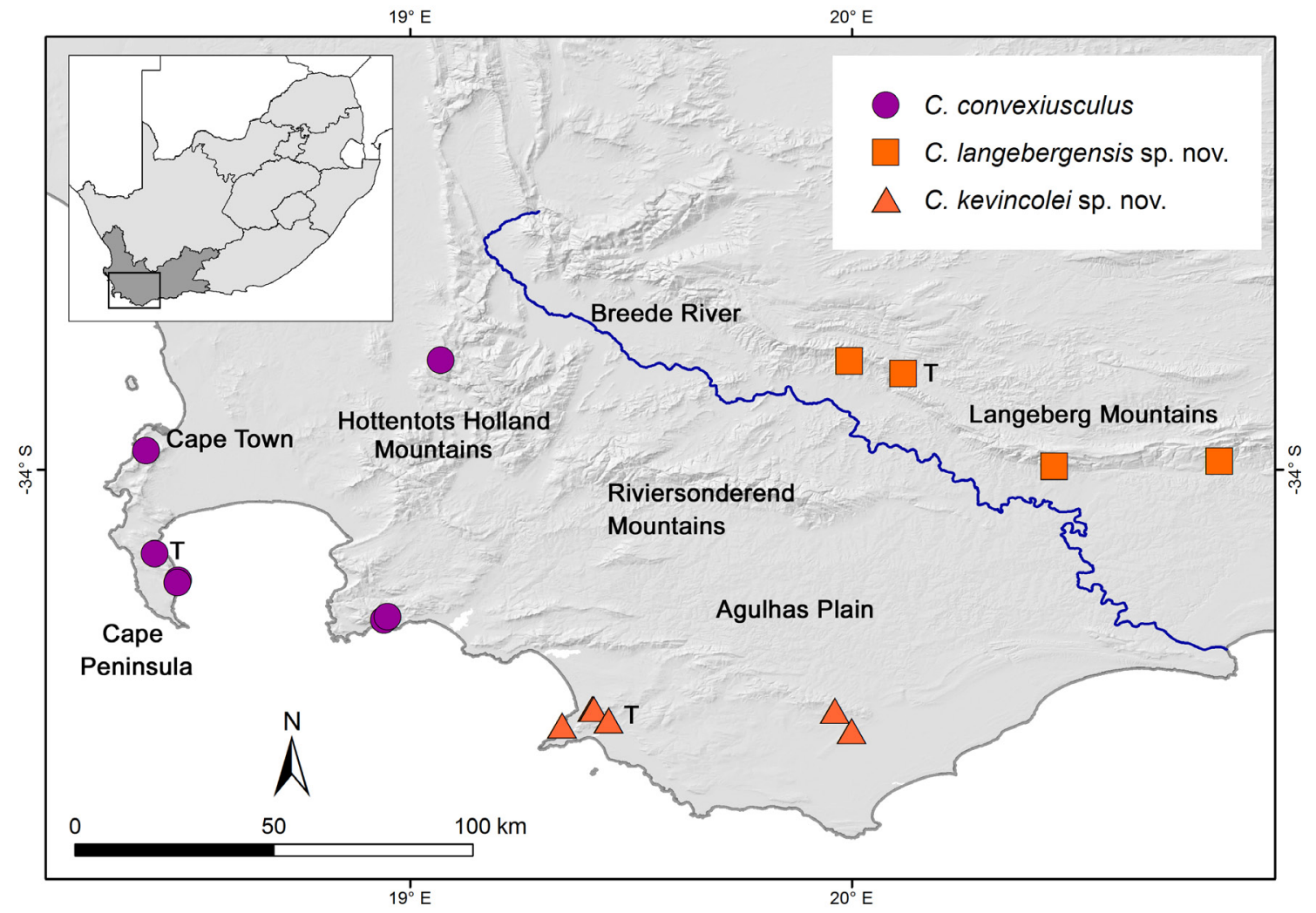

Fig. 5. Distribution map of the two major clades in the Western Cape province, the Southwestern Cape clade (purple) and the Overberg clade (orange). $T$ indicates type localities. 


\section{Distribution and habitat}

Western Cape, mountains of the Cape Peninsula and north-south running mountains to the east of the Cape Flats. Inland populations appear to be bounded by the upper Breede River valley and coastal populations by the relatively low-lying Agulhas Plain (Fig. 5). There are no records from the Riviersonderend Mountains.

Western Cape Afrotemperate forest (von Maltitz et al. 2003), very small patches in sheltered ravines; in leaf-litter.

\section{Remarks}

Connolly (1929) distinguished this species from C. alabastris on the basis of the second lateral tooth of the radula, that of $C$. convexiusculus having three large cusps and $C$. alabastris two. This is confirmed by comparing Fig. 4G and Fig. 7F. There are also differences in the periostracum and operculum discussed under $C$. alabastris. The molecular analyses placed $C$. convexiusculus and C. alabastris in different clades (Fig. 1).

Chondrocyclus alabastris (Craven, 1880)

Figs 6-7, 8A-B, 9

Cyclotus alabastris Craven, 1880: 619 (type loc.: Cape Recif, Algoa Bay [Craven]).

Cyclophorus (Maizania) alabastris - Kobelt 1902: 149.

Chondrocyclus alabastris - Connolly 1929: 238; 1939: 539.

\section{Diagnosis}

Shell small, very depressed, lenticular; protoconch mammillate and tilted; periostracum with axial costae developing at the periphery elongated triangular flanges usually with serrated edges; operculum flattened, exterior portion shallowly concave, with step-shaped multispiral lamella terminating in solid fringe reflexed over peristome; radula with two large cusps on second lateral tooth.

\section{Etymology}

From 'alabaster', an almost transparent white stone. In his description Craven (1880) describes the species as "semitransparent, of a pure white colour".

\section{Type material examined}

\section{Syntypes}

SOUTH AFRICA - Eastern Cape • 7 specimens; syntypes of Cyclotus alabastris Craven, 1880; Cape Colony, Algoa Bay, Cape Recif; A.E. Craven leg.; on Sand-Hills; 27 Feb. 1875; NHMUK 1891.3.7.4247. (Fig. 6A)

\section{Other material examined}

SOUTH AFRICA - Eastern Cape $\bullet 8$ specimens; Port Elizabeth, The Island Nature Reserve, indigenous Southern Coastal forest in south facing valley; $33.9867^{\circ} \mathrm{S}, 25.3715^{\circ} \mathrm{E}$; 18 Sep. 2008; M. Cole leg.; ELM D15931 - 36 specimens; same collection data as for preceding; 27 May 2011; M. Cole leg.; ELM D16885 - 7 specimens; same collection data as for preceding; ELM W03640 - 3 specimens; same collection data as for preceding; NHMUK 20120270 • 2 specimens; same collection data as for preceding; NMW.Z.2012.065.00003 - 1 specimen; Port Elizabeth, Settlers Park, indigenous riverine forest; $33.9703^{\circ} \mathrm{S}, 25.6123^{\circ}$ E; 16 Mar. 2005; A. Moussalli and D. Stuart-Fox leg.; in leaf-litter; NMSA W4602 5 specimens; Van Stadens River gorge, west of Port Elizabeth, tall forest on steep slope with 
COLE M.L., Revision of cyclophorid snails Chondrocyclus s.l.

stream running down to river; $33.9120^{\circ} \mathrm{S}, 25.2051^{\circ}$ E; 22 Sep. 2008; M. Cole leg.; ELM D15969 • 16 specimens; same collection data as for preceding; 27 Sep. 2011; M. Cole leg.; ELM D16882 • 2 specimens; same collection data as for preceding; ELM W03638 3 specimens; Loerie Restcamp, near PPC quarry; $33.7971^{\circ}$ S, $24.9654^{\circ}$ E; 22 Sep. 2008; M. Cole leg.; ELM D15924 • 24 specimens; Maitland Nature Reserve, $2 \mathrm{~km}$ from mouth on east side of river, forest on steep slope; $33.9774^{\circ} \mathrm{S}, 25.3121^{\circ} \mathrm{E}$; 26 Sep. 2011; M. Cole, D. Herbert and L. Davis leg.; ELM D16881 • 2 specimens; Ningi, (formerly Yellowwoods Farm), on west side of Maitland River $4.5 \mathrm{~km}$ upstream of mouth, riverine forest with large Yellowwoods; $33.9304^{\circ}$ S; $25.2083^{\circ}$ E; 27 Sep. 2011; M. Cole, D. Herbert and L. Davis leg.; ELM D16883 - 13 specimens; Ferndale, Patensie, Ratelkloof, valley of Noaga River; $33.7164^{\circ} \mathrm{S}, 24.8503^{\circ} \mathrm{E}$; 28 Sep. 2011; M. Cole, D. Herbert and L. Davis leg.; ELM D16884 • 5 specimens; same collection data as for preceding; ELM W03639 - 53 specimens; Gamtoos River mouth, dune forest east of mouth; 33.9574 S, $25.0477^{\circ}$ E; 40 m a.s.1.; 28 Sep. 2011; M. Cole, D. Herbert and L. Davis leg.; ELM D16886• 8 specimens; same collection data as for preceding; ELM W03641 1 specimen; Kap River, north bank, indigenous riverine forest on shady, south-facing slope; $33.4830^{\circ} \mathrm{S}, 27.0807^{\circ} \mathrm{E} ; 30 \mathrm{~m}$ a.s.l.; 13 May 2011; M. Cole leg.; ELM D16887 • 1 specimen; same collection data as for preceding; 30 Dec. 2002; M. Cole leg.; ELM W03026 • 34 specimens; Olifantskop, Southern Mistbelt forest; $33.3173^{\circ} \mathrm{S}, 26.4991^{\circ} \mathrm{E}$; 9 Sep. 2011; M. Cole, D. Herbert and L. Davis leg.; ELM D16890 8 specimens; same collection data as for preceding; ELM W03643 • 4 specimens; Van Stadens Pass, bottom of pass, west side of river, steep south facing slope; $33.9095^{\circ} \mathrm{S}, 25.1905^{\circ} \mathrm{E} ; 16$ Nov. 2012; M. and K. Cole, D. Herbert and L. Davis leg.; ELM D17016 4 specimens; Van Stadens Pass, near top of pass, steep north-facing slope; $33.9131^{\circ} \mathrm{S}$, 25.2047 ${ }^{\circ}$ E; 163 m a.s.1.; 16 Nov. 2012; M. Cole leg.; ELM D17222 • 9 specimens; Berg River crossing, east bank, $9 \mathrm{~km}$ E of Loerie, $7.5 \mathrm{~km} \mathrm{~N}$.W. of Van Stadens bridge; $33.8746^{\circ} \mathrm{S}, 25.1195^{\circ} \mathrm{E}$; 17 Nov. 2012; M. and K. Cole, D. Herbert and L. Davis leg.; ELM D17026 • 6 specimens; same collection data as for preceding; ELM W03668 48 specimens; Stinkhoutkloof, $11 \mathrm{~km} \mathrm{N.E} \mathrm{of} \mathrm{Loerie,} 15 \mathrm{~km} \mathrm{N.W.} \mathrm{of} \mathrm{Van}$ Stadens; $33.7993^{\circ}$ S, $25.0967^{\circ}$ E; 17 Nov. 2012; M. and K. Cole, D. Herbert, L. Davis and Edwards family leg.; ELM D17034 6 specimens; Addo National Park, Zuurberg section, forest in valley of river, on 4 hour trail; $33.3403^{\circ} \mathrm{S}, 25.7362^{\circ} \mathrm{E} ; 477 \mathrm{~m}$ a.s.1.; 19 Nov. 2012; M. and K. Cole leg.; ELM D17045 • 1 specimen; same collection data as for preceding; ELM W03676 - 7 specimens; Port Elizabeth, Lovemore Heights, south facing slope, Southern Coastal forest; $33.9928^{\circ} \mathrm{S}, 25.5121^{\circ} \mathrm{E} ; 278 \mathrm{~m}$ a.s. $1 . ; 18$ Nov. 2012; M. and K. Cole leg.; ELM D17120 • 1 specimen; same collection data as for preceding; ELM W03733 - 31 specimens; Grahamstown, Mountain Drive, south facing slope; $33.3281^{\circ} \mathrm{S}, 26.5006^{\circ} \mathrm{E}$; 10 Mar. 2007; M. Bursey and V. Ndibo leg.; in leaf-litter; ELM D15286 36 specimens; same collection data as for preceding; 20 Nov. 2009; M. Cole leg.; ELM D16888 18 specimens; same collection data as for preceding; ELM W03642 • 3 specimens; same collection data as for preceding; NHMUK 20120269 • 38 specimens; same collection data as for preceding; $33.3292^{\circ} \mathrm{S}, 26.4991^{\circ} \mathrm{E}$; 6 Feb. 2011; R. Daniels leg.; ELM D16889 • 1 specimen; same collection data as for preceding; ELM W3690 • 2 specimens; same collection data as for preceding; NMW.Z.2012.065.00002 13 specimens; Grahamstown, Belmont Valley; $33.3153^{\circ} \mathrm{S}, 26.5861^{\circ} \mathrm{E}$; 1978 ; D. Herbert leg.; NMSA W581 • 7 specimens; Paradise Kloof, $8 \mathrm{~km}$ SW of Grahamstown, runs down southwards into upper Howison's Poort (Palmiet River) from the Coldspring Ridge; $33.3444^{\circ} \mathrm{S}, 26.4466^{\circ} \mathrm{E}$; $710 \mathrm{~m}$ a.s.1.; 28 Feb. 2013; M. Cole leg.; collected at top of kloof; ELM D17220 • 9 specimens; same collection data as for preceding; ELM W03740 • 5 specimens; Coleridge, near Stones Hill, 8 km SE of Grahamstown, south facing slope, Southern Mistbelt Forest; 33.3334 ${ }^{\circ}$ S, 26.6156 ${ }^{\circ}$ E; 2 Mar. 2013; M. and S. Cole leg.; ELM D17221 • 2 specimens; same collection data as for preceding; ELM W03741.

\section{Description}

Shell (Fig. 6B-D). Small, usually very depressed, lenticular, adult diameter 3.7-5.32 mm, height 1.92-2.86 mm, diameter:height 1.79-2.28 $(\mathrm{n}=20)$ (from The Island Nature Reserve, Port Elizabeth, close to type locality). Variation in dimensions between populations is given in Table 1. Spire little exserted, protoconch acutely mammillate and tilted. Embryonic shell (Fig. 7A) approx. 2.25 whorls, 
Table 1. Measurements of Chondrocyclus alabastris (Craven, 1880), showing variation between populations; $\mathrm{D}=$ shell diameter, $\mathrm{H}=$ height, costae = number of axial ribs on body whorl, $\mathrm{Avg}=$ average.

\begin{tabular}{lccccccccccccc}
\hline Site & D max D min & Avg & H max H min & Avg & $\begin{array}{c}\text { D/H } \\
\text { max }\end{array}$ & $\begin{array}{c}\text { D/H } \\
\text { min }\end{array}$ & Avg & n & Costae & Avg & n \\
\hline Grahamstown & 6.31 & 5.13 & 5.88 & 3.45 & 2.66 & 3.09 & 2.09 & 1.76 & 1.91 & 21 & $75-97$ & 84 & 10 \\
van Stadens & 7.59 & 5.82 & 6.46 & 3.85 & 2.76 & 3.19 & 2.36 & 1.79 & 2.04 & 14 & $71-90$ & 81 & 7 \\
Olifantskop & 6.90 & 5.92 & 6.55 & 3.75 & 3.01 & 3.40 & 2.26 & 1.75 & 1.93 & 20 & $70-94$ & 82 & 9 \\
Ferndale & 7.10 & 5.72 & 6.32 & 3.35 & 2.56 & 2.95 & 2.38 & 2.00 & 2.15 & 12 & $77-81$ & 79 & 6 \\
Island & 5.32 & 3.70 & 4.48 & 2.86 & 1.92 & 2.96 & 2.28 & 1.79 & 1.96 & 20 & $74-82$ & 81 & 6 \\
Maitland & 6.56 & 4.44 & 5.36 & 3.55 & 2.17 & 2.74 & 2.26 & 1.80 & 1.97 & 13 & $77-87$ & 82 & 3 \\
Gamtoos & 5.05 & 4.17 & 6.78 & 2.96 & 2.36 & 3.88 & 1.88 & 1.63 & 1.75 & 20 & $67-83$ & 73 & 6 \\
\hline
\end{tabular}

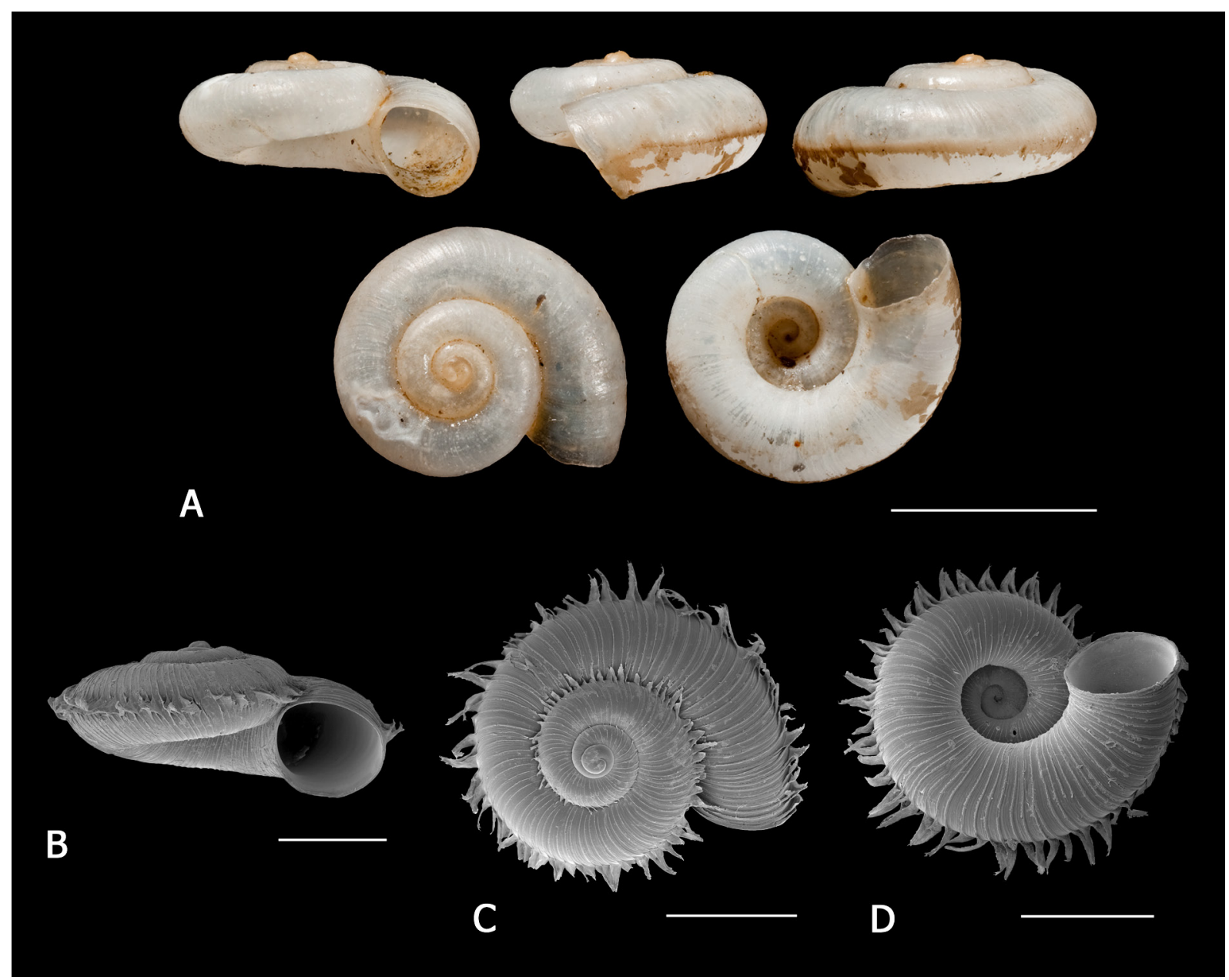

Fig. 6. Chondrocyclus alabastris (Craven, 1880). A. Syntype (NHMUK 1891.3.7.42). B. Aperture view (ELM D16882). C. Dorsal view (ELM W3640). D. Ventral view (ELM W3640). Scale bars: A= 3 mm; $\mathrm{B}-\mathrm{D}=2 \mathrm{~mm}$. 


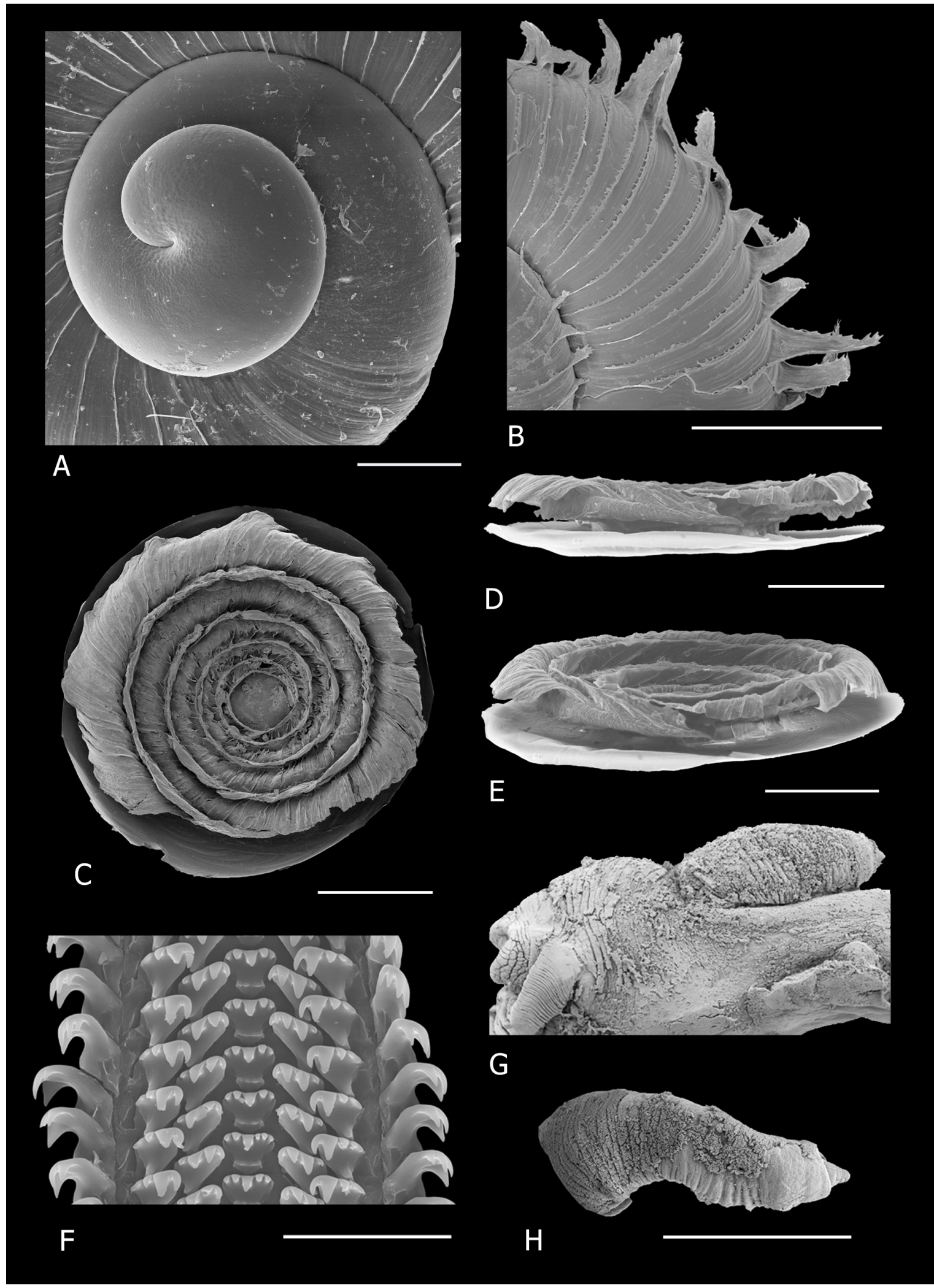

Fig. 7. Chondrocyclus alabastris (Craven, 1880). A. Protoconch (ELM D16888). B. Detail of axial lamellae of periostracum (ELM W3639). C-E. Operculum (ELM W3640). F. Portion of radula (ELM W3640). G. Penis, lateral view, showing position (ELM W3638). H. Penis, dorsal view (ELM W3642). Scale bars: A $=200 \mu \mathrm{m} ; \mathrm{B}, \mathrm{G}-\mathrm{H}=1 \mathrm{~mm} ; \mathrm{C}-\mathrm{E}=500 \mu \mathrm{m} ; \mathrm{F}=50 \mu \mathrm{m}$. 
microscopically malleate, sculpture strongest on earliest part, junction between embryonic shell and teleoconch evident with development of costae on teleoconch. Teleoconch comprising 2.5 whorls, convex, rapidly increasing, suture deeply impressed. Aperture circular, last whorl descending near aperture, peristome simple, continuous and free. Umbilicus wide and deep, exposing all the whorls. Periostracum glossy, honey-brown and lacquer-like with lamellate axial costae at regular intervals, 6797 on last whorl (average 80; $n=47$ ), their edges scalloped or serrated in the majority of populations (Fig. 8A) and expanded into elongated flanges at periphery, flanges smooth with a spine-tip in populations from around Grahamstown (Fig. 8B); intervals between costae with 3-6 microscopic axial threads. Shell translucent honey brown when fresh.

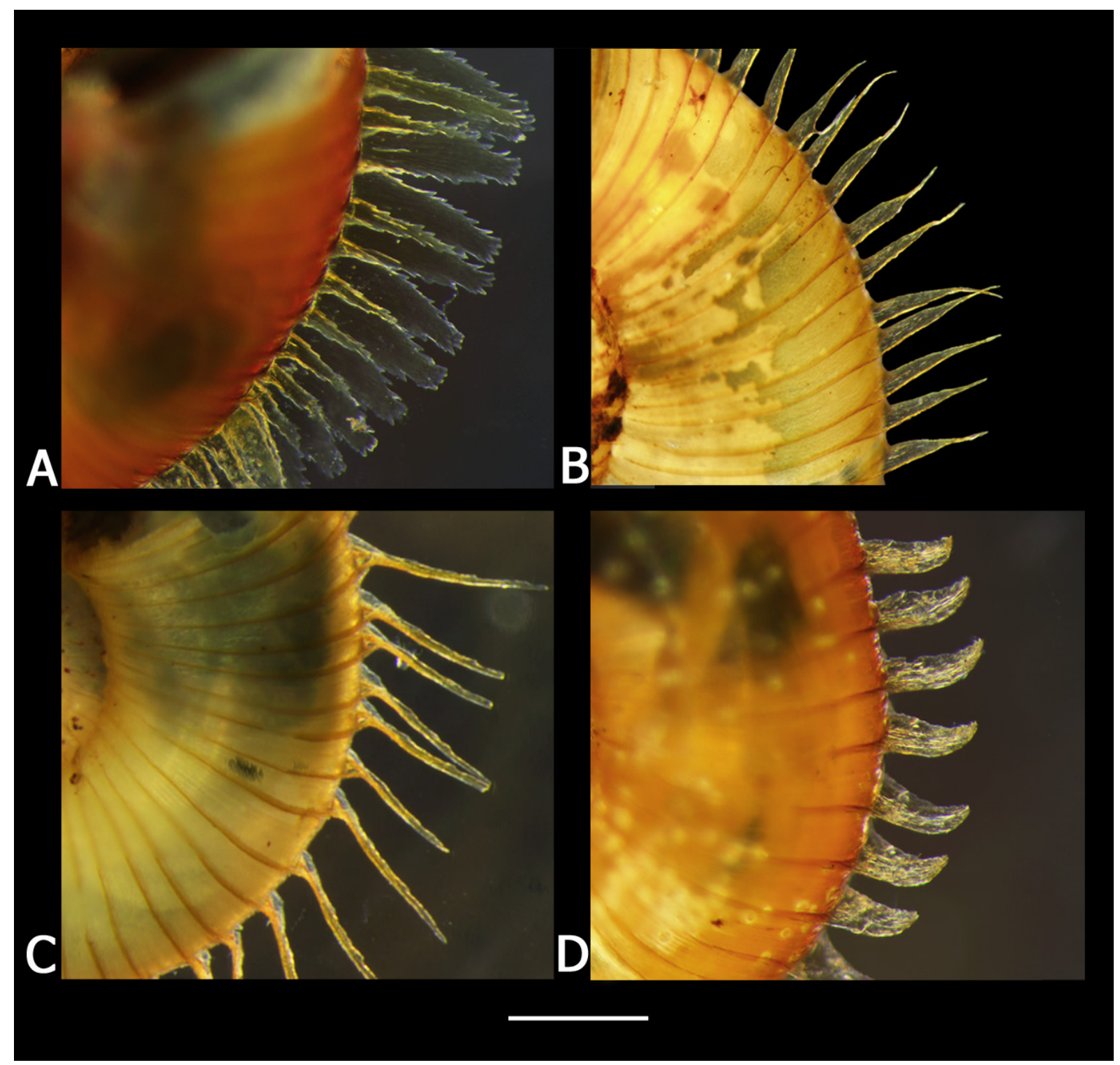

Fig. 8. Close-up of periostracum of species of the Southern-Eastern Cape clade and Chondrocyclus convexiusculus (Pfeiffer, 1855), showing variation in detail of flanges at periphery. A. C. alabastris (Craven, 1880) (serrated edge typical) (ELM W3640). B. C. alabastris, Grahamstown area (ELM W3690). C. C. convexiusculus (ELM W3636). D. C. herberti sp. nov. (ELM W3691). Scale bar $=500 \mu \mathrm{m}$. 
Living ANIMAL. Dark grey.

Operculum (Fig. 7C-E). Duplex outer portion shallowly concave, and consisting of a multispiral lamella with five whorls, at its growing edge the top edge of the lamellar blade is sloping, becoming perpendicular to the disc where it is attached; fringe of fused bristles emanates near top of vertical portion of lamellar blade on its outer surface and curves upwards and outwards forming a shallow furrow between fringe and lamellar blade, a second very short fringe emanates from lower down on the lamellar blade; top edge of lamella does not project above level of fringe; fringe of each whorl fused to lamella of following whorl. Fringe overlaps disc slightly, but operculum can be withdrawn into aperture.

Radula (Fig. 7F). Rachidian with five cusps, central approx. twice as long as two on either side of it; first lateral tooth with four cusps and sometimes a vestigial fifth, first three cusps (from centre) gradually increasing in size and fourth considerably smaller; second lateral tooth with two large cusps and two small cusps towards outside.

Penis (Fig. 7G-H). Shaft more or less straight-sided and slightly flattened, with numerous annular rugae, intromittent organ short.

\section{Distribution and habitat}

Endemic to the Eastern Cape, centered around Port Elizabeth and including the Albany district (Fig. 9). Found in a wider variety of vegetation types than other Chondrocyclus species: Algoa Dune Strandveld, Albany Coastal Forest, Southern Mistbelt Forest, Great Fish Thicket (von Maltitz et al. 2003; Hoare et al. 2006; Mucina et al. 2006); in leaf-litter.

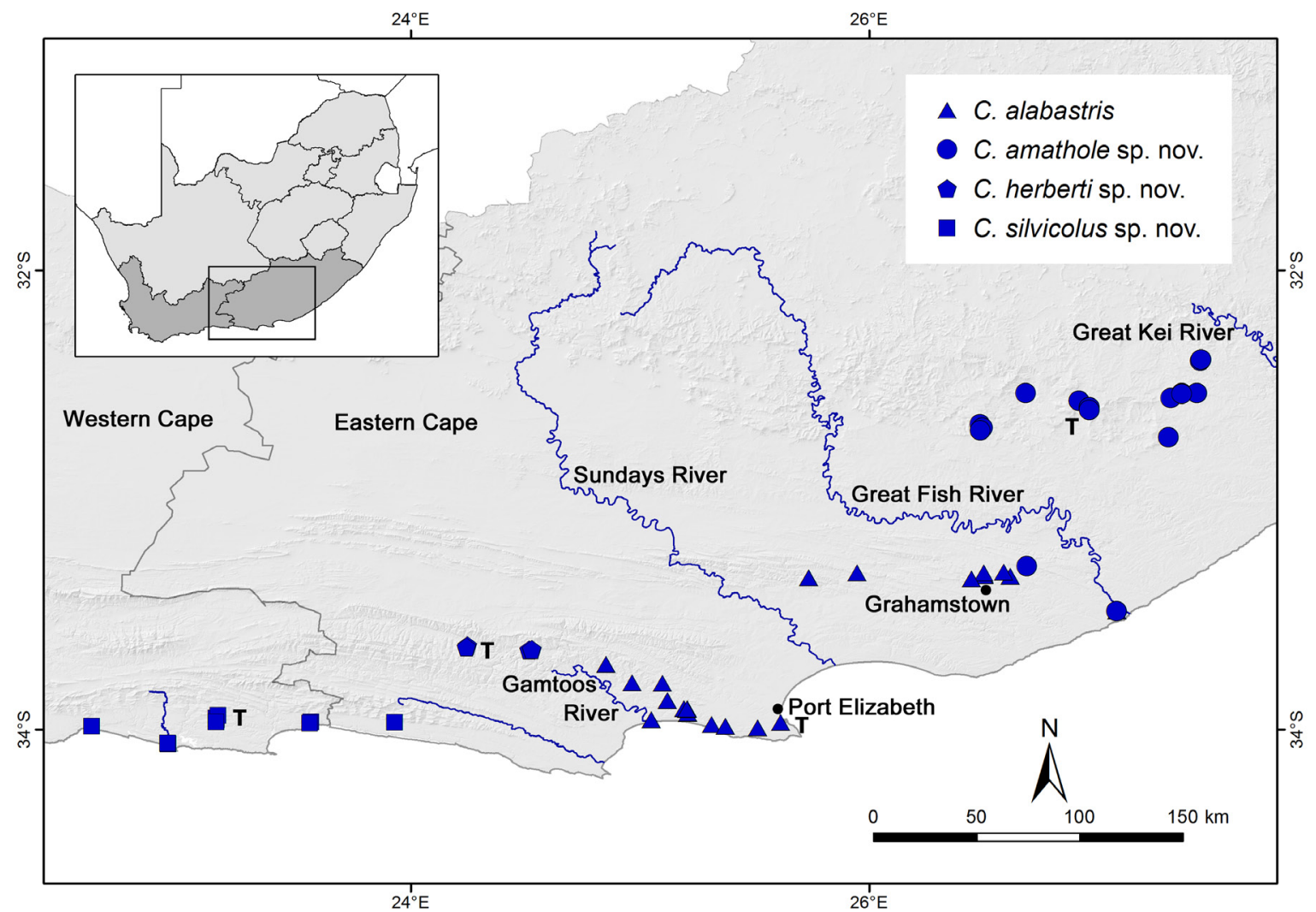

Fig. 9. Distribution map of Chondrocyclus species in the Southern-Eastern Cape clade in the southern Cape area of the Western Cape province and the western half of the Eastern Cape province. $T$ indicates type localities. Major cities and rivers are labelled. 


\section{Remarks}

There is variation in size of shells between populations (Table 1), an observation also recorded by Connolly (1939). Shells in some populations are among the largest recorded in the genus (the only other species attaining a similar size is $C$. amathole sp. nov.). However, the types (Fig. 6A) from Cape Receife, populations at The Island Nature Reserve (40 km west of type locality) and at Gamtoos River mouth are smaller on average and the population at Gamtoos mouth has a distinctly less depressed shape than is typical for the species. Its diameter/height proportions resemble those of relatively less depressed species, e.g., C. convexiusculus, C. herberti sp. nov. and A. exsertus gen. et comb. nov.

There was a relatively large intraspecific divergence in C. alabastris (Cole et al. 2019) and the species contained several very well-supported subclades (Fig. 1). There was a distinct lineage in the mistbelt forest patches on the Rietberg ridge south of Grahamstown (Paradise Kloof and Coleridge in Fig. 1). This lineage exhibited a conspicuous variation from other populations of $C$. alabastris: the peripheral extensions of the axial lamellae were not serrated along the edges and each flange tapered gradually into a short spine tip (Fig. 8B). Specimens from these localities superficially resembled C. convexiusculus (Fig. 8C). However, the spines are longer in C. convexiusculus, emanating from a relatively short, broad triangular proximal portion while in $C$. alabastris the triangular flanges taper gradually into the short spine tip (Fig. 8B).

The lamellar blade of the outer portion of the operculum of $C$. alabastris is relatively lower and hence the operculum is less concave than that of $C$. convexiusculus, and has a very short fringe below the long fringe, absent in C. convexiusculus.

\section{Chondrocyclus herberti sp. nov. urn:1sid:zoobank.org:act:4265F23E-DB10-46D8-B263-E90EA206C53F} Figs $8 \mathrm{D}, 9,10 \mathrm{~A}-\mathrm{B}, 12$

\section{Diagnosis}

Shell very small, moderately depressed; periostracum with widely spaced axial costae bearing broad, distally rounded flanges at the shell periphery; operculum duplex, exterior portion shallowly concave, with step-shaped multispiral lamella terminating in a long solid fringe reflexed over peristome; radula with two large cusps on second lateral tooth.

\section{Etymology}

Named for Dai Herbert, Malacologist at the KwaZulu-Natal Museum for 33 years, in recognition of his expertise in South African molluscs and in acknowledgement of his mentorship.

\section{Type material examined}

\section{Holotype}

SOUTH AFRICA - Eastern Cape - Baviaanskloof, Western Poortjies area; $33.6536^{\circ} \mathrm{S}, 24.5161^{\circ} \mathrm{E}$; 9 Oct. 2000; D. Herbert leg.; riverine thicket, in leaf-litter; NMSA P1043/T4277. (Fig. 10A-B)

\section{Paratypes}

SOUTH AFRICA - Eastern Cape • 39 specimens; same collection data as for holotype; NMSA V8632/ T4127 15 specimens; Baviaanskloof, Poortjies area, rocky bank adjacent to Witte River; $33.6537^{\circ} \mathrm{S}$, $24.527^{\circ} \mathrm{E} ; 258 \mathrm{~m}$ a.s.1.; 26 Jan. 2011; M. Cole, V. Ndibo and R. Daniels leg.; riverine thicket, in leaf litter; ELM D16891/T41 - 1 specimen; same collection data as for preceding; ELM W3691/T42 • 1 specimen; same collection data as for preceding; NMSA W9279/T3077 • 2 specimens; same collection data as for preceding; NHMUK 20120285 • 2 specimens; same collection data as for preceding; 
COLE M.L., Revision of cyclophorid snails Chondrocyclus s.l.

NMW.Z.2012.065.00012 3 specimens; same collection data as for preceding; RMNH MOL.330501 • 16 specimens; Baviaanskloof, Poortjies area; $33.6536^{\circ} \mathrm{S}, 24.5272^{\circ} \mathrm{E} ; 9$ Oct. 2000; D. Herbert leg.; riverine thicket, in leaf-litter; NMSA V8576/T4129 - 20 specimens; Baviaanskloof, Geelhoutbos, forest in narrow kloof; $33.6335^{\circ} \mathrm{S}, 24.2449^{\circ} \mathrm{E}$; 11 Oct. 2000; D. Herbert leg.; in leaf-litter; NMSA V8763/T4130 - 9 specimens; Baviaanskloof, Geelhoutbos, near pool and weir, forest in narrow kloof; 33.6430 ${ }^{\circ}$ S, $24.2426^{\circ}$ E; 468 m a.s.1.; 9 Mar. 2015; M. Cole leg.; in leaf-litter; ELM D17990/T43 • 34 specimens; Baviaanskloof, Geelhoutbos, near Hikers' hut, forest in narrow kloof; $33.6356^{\circ} \mathrm{S}, 24.2457^{\circ} \mathrm{E}$; 373 m a.s.l.; 9 Mar. 2015; M. Cole leg.; in leaf-litter; ELM D17986/T44 • 1 specimen; Baviaanskloof wilderness area, Grassnek, thicket/fynbos transition; $33.6430^{\circ} \mathrm{S}, 24.2426^{\circ} \mathrm{E} ; 11$ Oct. 2000; D. Herbert leg.; under stones and amongst leaf litter; NMSA V8648/T4128.

\section{Other material examined}

SOUTH AFRICA - Eastern Cape 2 specimens; Baviaanskloof, Western Poortjies area, rocky bank adjacent to Witte River; $33.6542^{\circ} \mathrm{S}, 245160^{\circ} \mathrm{E} ; 8$ Mar. 2015; M. Cole leg.; riverine thicket, in leaf litter; ELM D17995.

\section{Description}

SHELl (Fig. 12A-C). Very small, moderately depressed, adult diameter 3.43-4.31 mm, height 2.09$2.69 \mathrm{~mm}$, diameter:height $1.46-1.94(\mathrm{n}=20)$. Spire moderately exserted, protoconch acutely mammillate and tilted (Fig. 12A). Embryonic shell (Fig. 12D) just over two whorls, microscopically malleate for approx. two whorls, axial costae begin to develop just after two whorls. Teleoconch comprising approx. 2.5 whorls, very convex, rapidly increasing, suture impressed. Aperture circular, last whorl descending near aperture, peristome simple, continuous and free. Umbilicus deep, exposing all the whorls. Periostracum glossy, light yellowish-brown and lacquer-like with relatively widely spaced lamellate axial costae at regular intervals, 39-51 $(\mathrm{n}=22)$ on last whorl (Fig. 12A-C), which produce broad flanges with rounded apices at periphery (Fig. 8D, 12E); intervals between costae with six to nine distinct microscopic axial threads. Shell translucent and corneous when fresh.

LiVING ANIMAL. Very dark grey.

OPERCULum (Fig. 12G-H). Duplex, outer portion shallowly concave and consisting of multispiral lamella with 4.5 whorls, each step-shaped and increasing in height towards outside, sloping at growing edge; very long fringe of fused bristles emanates near top of lamellar blade with a slight groove between fringe and lamellar blade; lamellar blade does not project above level of fringe; fringe of each whorl fused to lamella of following whorl.

RADULA (Fig. 12F). Rachidian with five cusps, central one approx. twice length of outer two on each side; first lateral tooth with four cusps and a vestigial fifth, third cusp (from centre) the largest; second lateral tooth with two very large cusps and two small ones on the outer side (outermost sometimes vestigial).

Penis (Fig. 12I). Shaft more or less cylindrical, distal half slightly expanded on left, intromittent organ short.

\section{Distribution and habitat}

Eastern Cape, Baviaanskloof (Fig. 9). Indigenous forest patches in narrow ravines (Western Cape Afrotemperate Forest of von Maltitz et al. 2003) and Albany subtropical thicket (Groot Thicket group) (Hoare et al. 2006), in leaf-litter; also in subtropical thicket/fynbos transition, under stones and amongst leaf litter. 


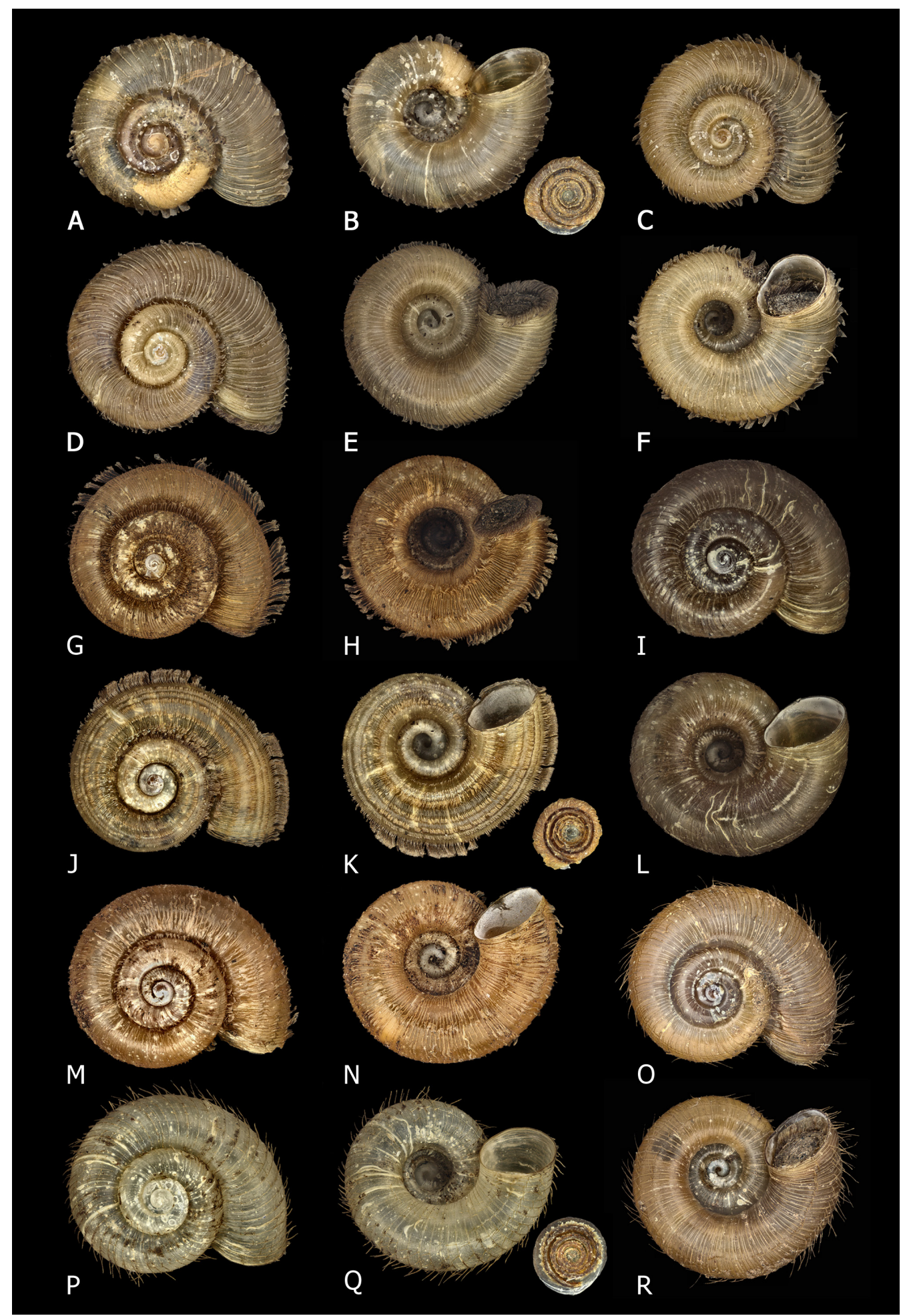

Fig. 10. Holotypes of species of Chondrocyclus Ancey, 1898. A-B. C. herberti sp. nov., diameter $3.70 \mathrm{~mm}$ (NMSA P1043/T4277). C, F. C. silvicolus sp. nov., diameter $5.82 \mathrm{~mm}$ (NMSA P0639/T4156). D-E. C. amathole sp. nov., diameter $6.01 \mathrm{~mm}$ (NMSA P0640/T4157). G-H. C. pondoensis sp. nov., diameter $5.92 \mathrm{~mm}$ (NMSA P0643/T4160). I, L. C. devilliersi sp. nov., diameter $5.23 \mathrm{~mm}$ (NMSA P1141/ T4312). J-K. C. pulcherrimus sp. nov., diameter 4.34 mm (NMSA W9272/T3075). M-N. C. cooperae sp. nov., diameter $4.93 \mathrm{~mm}$ (NMSA W9271/T3074). O, R. C. langebergensis sp. nov., diameter $5.13 \mathrm{~mm}$ (NMSA P0642/T4159). P-Q. C. kevincolei sp. nov., diameter 4.24 mm (NMSA P9270/T3073). 

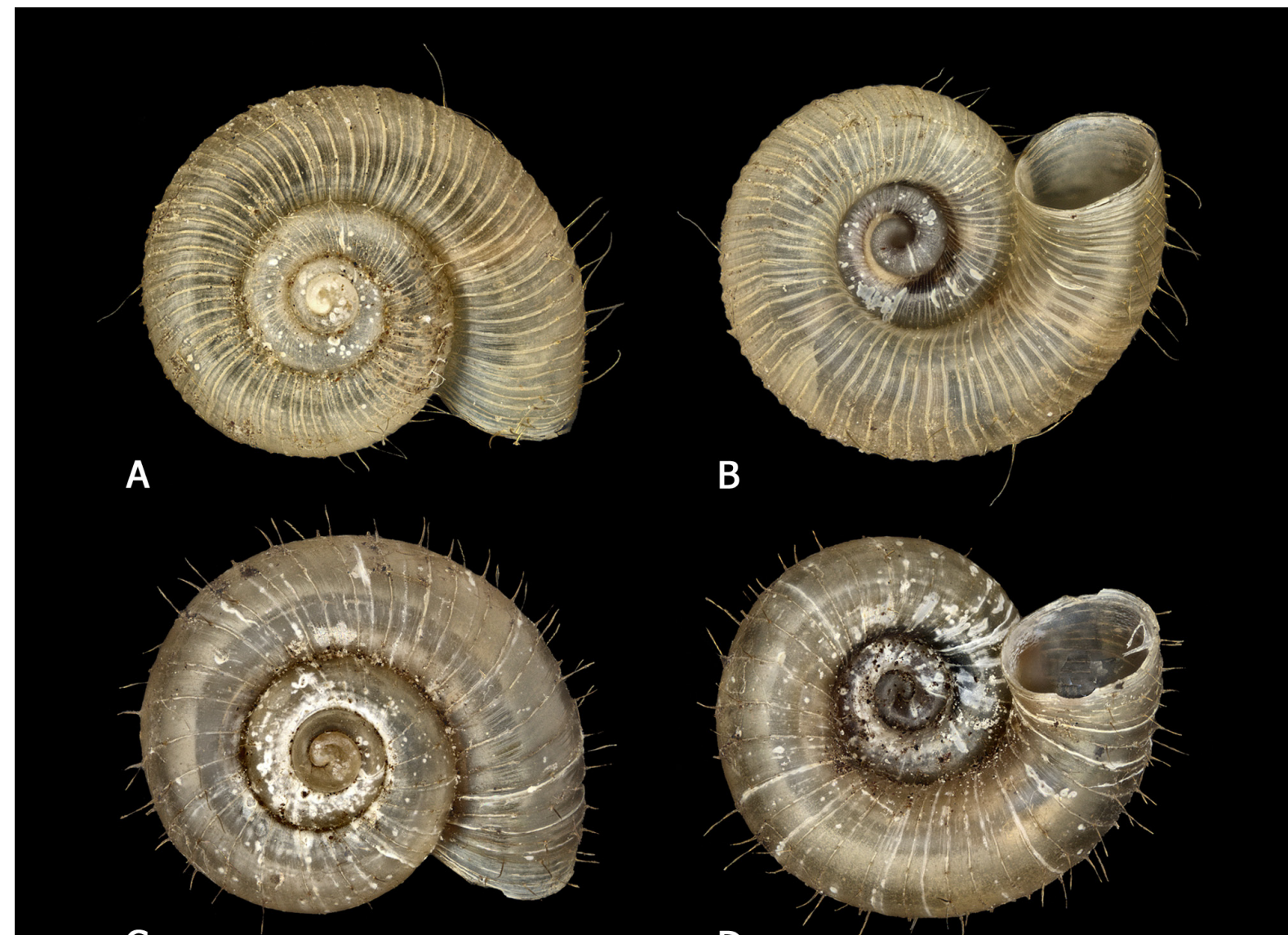

C
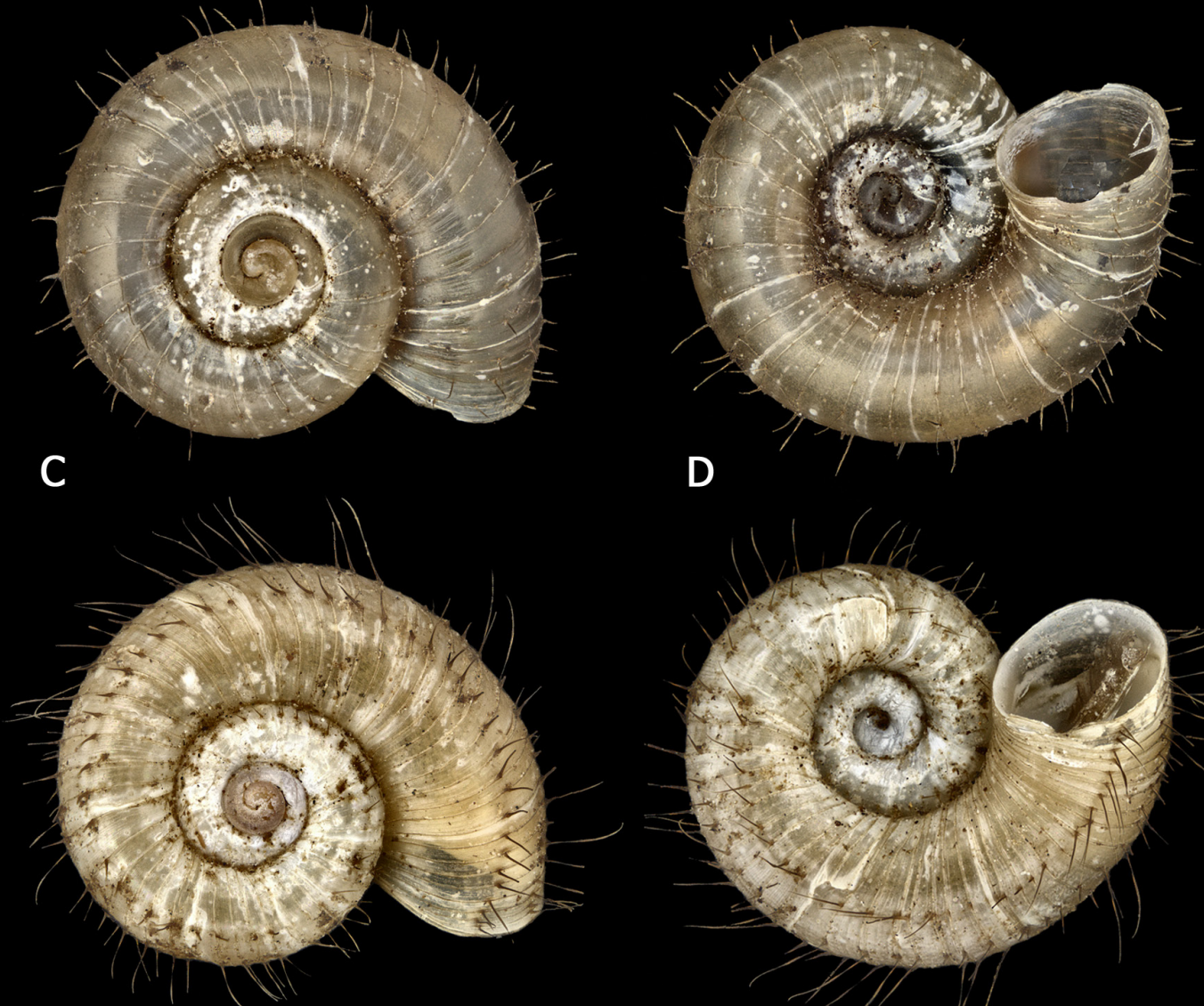

E

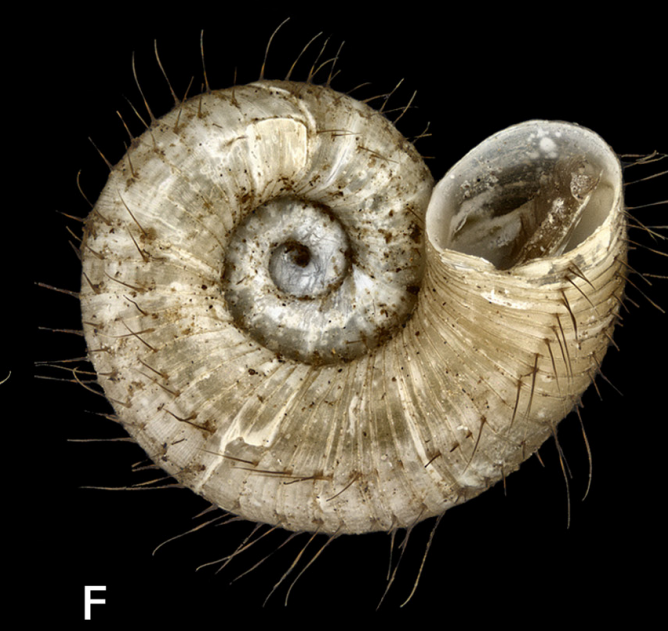

Fig. 11. Holotypes of species of Afrocyclus gen. nov. A-B. A. oxygala gen. et sp. nov., diameter $2.86 \mathrm{~mm}$ (NMSA P0638/T4153). C-D. A. potteri gen. et sp. nov., diameter 2.86 mm (NMSA P1125/T4283). E-F. A. bhaca gen. et sp. nov., diameter 2.87 mm (NMSA P1124/T4282). 


\section{Remarks}

The shell is less depressed than in the majority of other species of Chondrocyclus. The population of C. alabastris at Gamtoos River mouth has similar proportions but the periostracal flanges are serrated. The periostracum of $C$. herberti sp. nov. is distinctive; the flanges have broadly rounded apices and an unserrated margin. C. convexiusculus also has similar proportions and widely spaced costae, but the shape of the flanges as well as the radulae, distinguish the species. The operculum of $C$. herberti sp. nov. is more concave than that of $C$. alabastris and lacks the furrow between the vertical portion of lamellar blade and fringe.

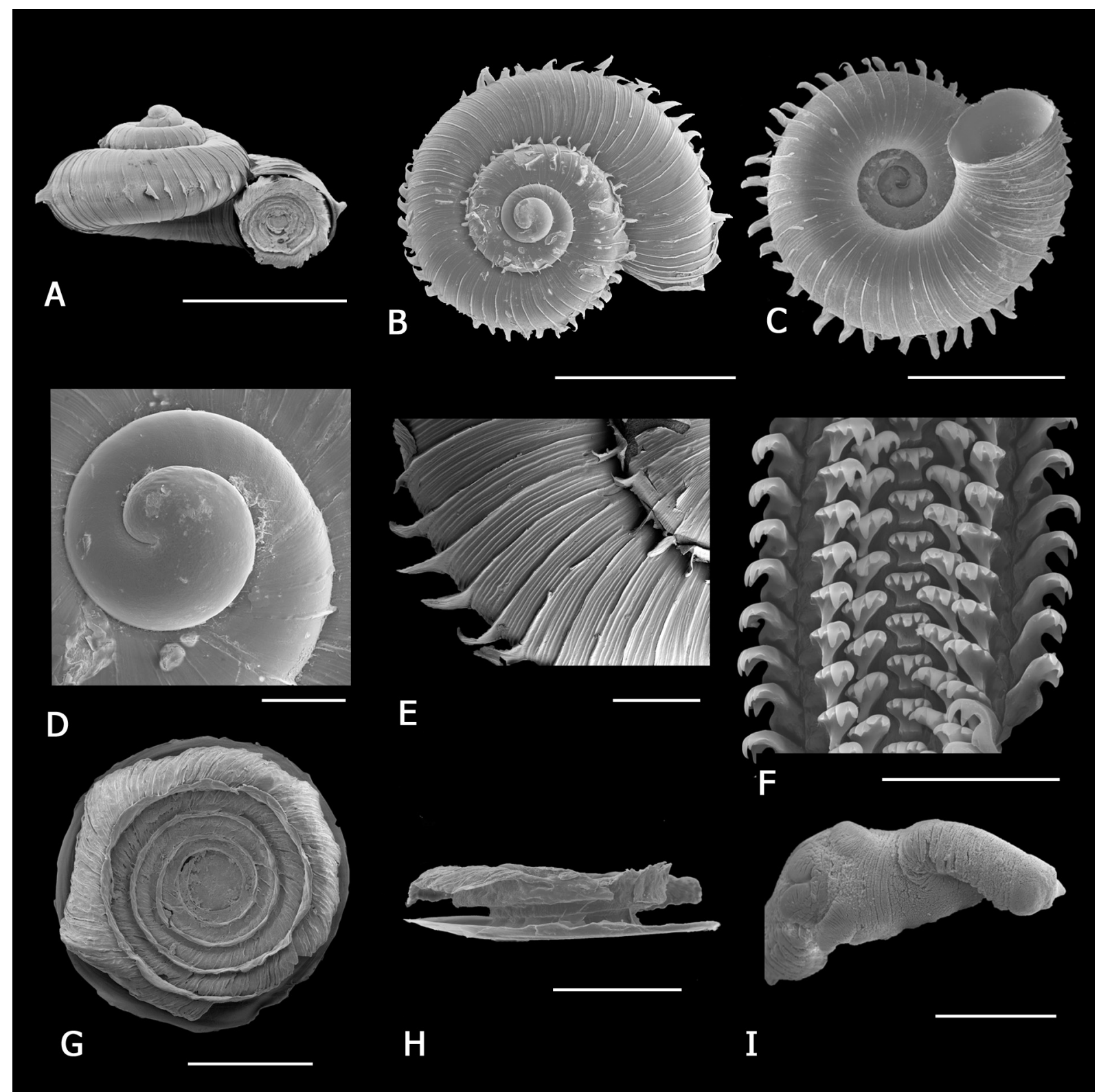

Fig. 12. Chondrocyclus herberti sp. nov. A. Aperture view (NMSA V8576/T4129). B. Dorsal view (ELM W3691/T42). C. Ventral view (ELM W3691/T42). D. Protoconch (NMSA V8632/T4127). E. Detail of axial lamellae of periostracum (NMSA V8576/T4129). F. Portion of radula (ELM W3691/T42). G-H. Operculum (ELM W3691/T42). I. Penis, dorsal view, showing position behind right tentacle (ELM W3691/T42). Scale bars: A-C $=2 \mathrm{~mm}$; D $=200 \mu \mathrm{m}$; E, G-H $=500 \mu \mathrm{m} ; \mathrm{F}=50 \mu \mathrm{m} ; \mathrm{I}=1 \mathrm{~mm}$. 
COLE M.L., Revision of cyclophorid snails Chondrocyclus s.l.

Chondrocyclus herberti sp. nov. is known only from the narrow valley of the Baviaanskloof, in isolated patches of relatively dry thicket and in thicket/fynbos transitional areas. C. herberti sp. nov. and C. alabastris have not been recorded sympatrically, although they occur in steep-sided river valleys in close proximity to each other (Fig. 9). Both of these valleys are tributaries of the Gamtoos River, a postulated dispersal corridor between the coast and the Baviaanskloof (Geldenhuys 1997). Watersheds may have been significant barriers to gene flow for thicket plant and insect species during glacial periods as thicket retracted downward into catchment valleys and survived in isolated refugia (Price et al. 2010; Potts et al. 2012). Terrestrial fauna with poor dispersal ability were also bounded by watersheds during Pleistocene climate cycling (Herbert \& Moussalli 2010).

When the animals were killed by drowning, they survived for a couple of weeks fully submerged with head and foot extended, which although not quantified, was longer than any other species. Chondrocyclus herberti sp. nov. can be very abundant; D. Herbert (pers. comm.) who first collected the species at Poortjies, found in excess of 1000 shells per $\mathrm{m}^{2}$ in a leaf litter sample.

Chondrocyclus silvicolus sp. nov.

urn:1sid:zoobank.org:act:6B37F514-8877-4BF0-8DC2-8B3EC2A17702

Figs $9,10 \mathrm{C}, \mathrm{F}, 13$

Chondrocyclus alabastris - Connolly 1939: 539

\section{Diagnosis}

Shell small, moderately depressed; protoconch mammillate and tilted; periostracum with widely spaced axial costae developing at the periphery broad flanges with pointed tips, tips are rounded not spinetipped; operculum duplex, exterior portion shallowly concave, with step-shaped multispiral lamella terminating in a long solid fringe reflexed over peristome; radula with two large cusps on second lateral tooth.

\section{Etymology}

The specific name is derived from the Latin 'silvicolus', meaning 'an inhabitant of the woods' and referring to the occurrence of the species in the largest forest blocks in South Africa, in the Knysna area.

\section{Type material examined}

\section{Holotype}

SOUTH AFRICA - Western Cape • Knysna Forest, Garden Route National Park, Diepwalle; $33.95^{\circ} \mathrm{S}$, 23.15 E; 28 Jan. 2011; M. Cole, V. Ndibo and R. Daniels leg.; NMSA P0639/T4156. (Fig. 10C, F)

\section{Paratypes}

SOUTH AFRICA - Western Cape 1 specimen; same collection data as for holotype; ELM D16892/ T45 4 specimens; same collection data as for holotype; ELM W3644/T46 • 1 specimen; Knysna Forest, Diepwalle, Ysterhoutrug; $33.9506^{\circ} \mathrm{S}, 23.1496^{\circ} \mathrm{E} ; 28$ Jan. 2011; M. Cole, V. Ndibo and R. Daniels leg.; ELM D16963/T45 4 specimens; same collection data as for preceding; NHMUK 20160073 3 specimens; same collection data as for preceding; NMW.Z.2016.003.00001 4 specimens; same collection data as for preceding; RMNH.MOL.338283 • 3 specimens; Knysna Forest Diepwalle, Ysterhoutrug; $33.966^{\circ} \mathrm{S}$, $23.150^{\circ}$ E; 28 Apr. 1997; D. Herbert leg.; sorted from leaf-litter; NMSA V4710/T4126 • 1 specimen; Knysna Forest, Diepwalle, vicinity of King Edward VII Big Tree; $33.9562^{\circ} \mathrm{S}, 23.1521^{\circ} \mathrm{E}$; 28 Jan. 2011; M. Cole, V. Ndibo and R. Daniels leg.; ELM D16962/T53 • 17 specimens; Tsitsikamma Forest, near Paul Sauer Bridge; $33.950^{\circ}$ S, $23.933^{\circ}$ E, 28 Apr. 1997; D. Herbert leg.; sorted from leaf-litter; NMSA V4730/T4125 • 31 specimens; Tsitsikama Forest, near Paul Sauer bridge over Storms River, $33.9674^{\circ} \mathrm{S}$, 23.9293 E; 27 Jan. 2011; M. Cole, V. Ndibo and R. Daniels leg.; ELM D16893/T52 • 1 dry specimen; 
same collection data as for preceding; NHMUK 20160074 • 1 specimen in ethanol; same collection data as for preceding; NHMUK 20160075 - 1 specimen; same collection data as for preceding;

RMNH.MOL338284 - 14 specimens; same collection data as for preceding; ELM W3645/T51 • 12 specimens; Goukamma N.R., 10 km west of Knysna, banks of Goukamma River 2.7 km upstream of mouth, riverine forest below River Lodge; $34.0591^{\circ} \mathrm{S}, 22.9389^{\circ} \mathrm{E} ; 12 \mathrm{Mar}$. 2015; M. Cole leg.; ELM D17939/T47 • 4 specimens; same collection data as for preceding; ELM W 3869/T48 • 10 specimens; Wilderness National Park, trail along west bank of Touw River opposite Ebb and Flow North campsite; 33.9843 ${ }^{\circ}$ S, $22.6073^{\circ}$ E; 12 Mar. 2015; M. Cole leg.; ELM D17946/T50 • 1 specimen; same collection data as for preceding; ELM W3871/T49.

\section{Other material examined}

SOUTH AFRICA - Western Cape 1 specimen; Tsitsikama Forest, near Paul Sauer bridge over Storms River; 33.9674 S, 23.9293 E; 16 Aug. 2014; M. Cole leg.; ELM D17972 • 2 specimens; Natures Valley, Kalanderkloof Trail, opposite Devasselot Restcamp, east-facing rocky slope; $33.971^{\circ} \mathrm{S}, 23.558^{\circ} \mathrm{E} ; 27$ Jan. 2011; M. Cole, V. Ndibo and R. Daniels leg.; ELM D16997 • 4 specimens; Natures Valley, North side of Groot River, near Devasselot Restcamp; $33.966^{\circ} \mathrm{S}, 23.563^{\circ} \mathrm{E} ; 27$ Jan. 2011; M. Cole, V. Ndibo and R. Daniels leg.; ELM D16894 • 1 specimen; Knysna Forest, Diepwalle, Velsbroekdraai; $33.9382^{\circ}$ S, 23.1574 E; 28 Jan. 2011; M. Cole, V. Ndibo and R. Daniels leg.; ELM D16964 • 1 specimen; Goukamma Nature Reserve, $10 \mathrm{~km}$ west of Knysna, on banks of Goukamma River, $2.3 \mathrm{~km}$ upstream of mouth, riverine forest behind Forest Lodge; $34.0614^{\circ} \mathrm{S}, 22.9396^{\circ} \mathrm{E}$; 12 Mar. 2015; M. Cole leg.; ELM D17959 • 4 specimens; Goukamma Nature Reserve, $10 \mathrm{~km}$ west of Knysna, on banks of Goukamma River, $2.3 \mathrm{~km}$ upstream of mouth, riverine forest behind Forest Lodge; $34.0614^{\circ} \mathrm{S}, 22.9396^{\circ} \mathrm{E}$; 15 Mar. 2014; M. Cole leg.; ELM D17965.

\section{Description}

SHELl (Fig. 13A-C). Small, moderately depressed, adult diameter 3.76-6.10 mm, height 2.09-3.84 mm, diameter:height 1.5-1.97 $(\mathrm{n}=49)$. Spire moderately exserted, protoconch mammillate and tilted. Embryonic shell (Fig. 13D) approx. 2.5 whorls, microscopically malleate, junction between embryonic shell and teleoconch evident with development of costae on teleoconch. Teleoconch comprising approx. 2.5 whorls, very convex, rapidly increasing, suture impressed. Aperture circular, last whorl descending near aperture, peristome simple, continuous and free. Umbilicus wide and deep, exposing all the whorls. Periostracum glossy, light yellowish-brown and lacquer-like with relatively widely spaced ridged, lamellate axial costae at regular intervals, 59-79 $(\mathrm{n}=13)$ on last whorl, which produce broad, pointed flanges with rounded tips at periphery (Fig. 13E); intervals between costae with six to nine distinct microscopic axial threads. Shell translucent golden brown or creamy white when fresh.

Living ANIMAL. Head, tentacles and snout pigmented with grey; underside of foot creamy white.

OPERCULUM (Fig. 13G-H). Duplex, outer portion shallowly concave and consisting of multispiral lamella with 4.75 whorls, each step-shaped and increasing in height towards outside, sloping at growing edge; long fringe of fused bristles emanates near top of lamellar blade with a slight groove between fringe and lamellar blade; lamellar blade does not project above level of fringe; fringe of each whorl fused to lamella of following whorl.

Radula (Fig. 13F). Rachidian with five cusps, central one approx. twice length of outer two on each side; first lateral tooth with three large cusps, one small and a vestigial fifth, third cusp (from centre) the largest; second lateral tooth with two very large cusps and two small ones on the outer side (outermost sometimes vestigial).

PENIS (Fig. 13I). Shaft more or less cylindrical, intromittent organ short. 
COLE M.L., Revision of cyclophorid snails Chondrocyclus s.l.

Table 2. Measurements of Chondrocyclus herberti sp. nov. and C. silvicolus sp. nov., showing differences between the species; $\mathrm{D}=$ shell diameter, $\mathrm{H}=$ height, costae = number of axial ribs on body whorl, avg = average.

\begin{tabular}{lccccccccccccc}
\hline Species & D max & $\mathbf{D}$ min & Avg & H max H min & Avg & D/H max & D/H min & Avg & n & Costae & Avg & n \\
\hline C. herberti & 4.31 & 3.43 & 3.85 & 2.69 & 2.09 & 2.34 & 1.94 & 1.46 & 1.65 & 23 & $39-51$ & 43 & 22 \\
C. silvicolus & 6.10 & 3.76 & 5.17 & 3.84 & 2.09 & 3.03 & 1.97 & 1.50 & 1.71 & 49 & $59-79$ & 69 & 13 \\
\hline
\end{tabular}

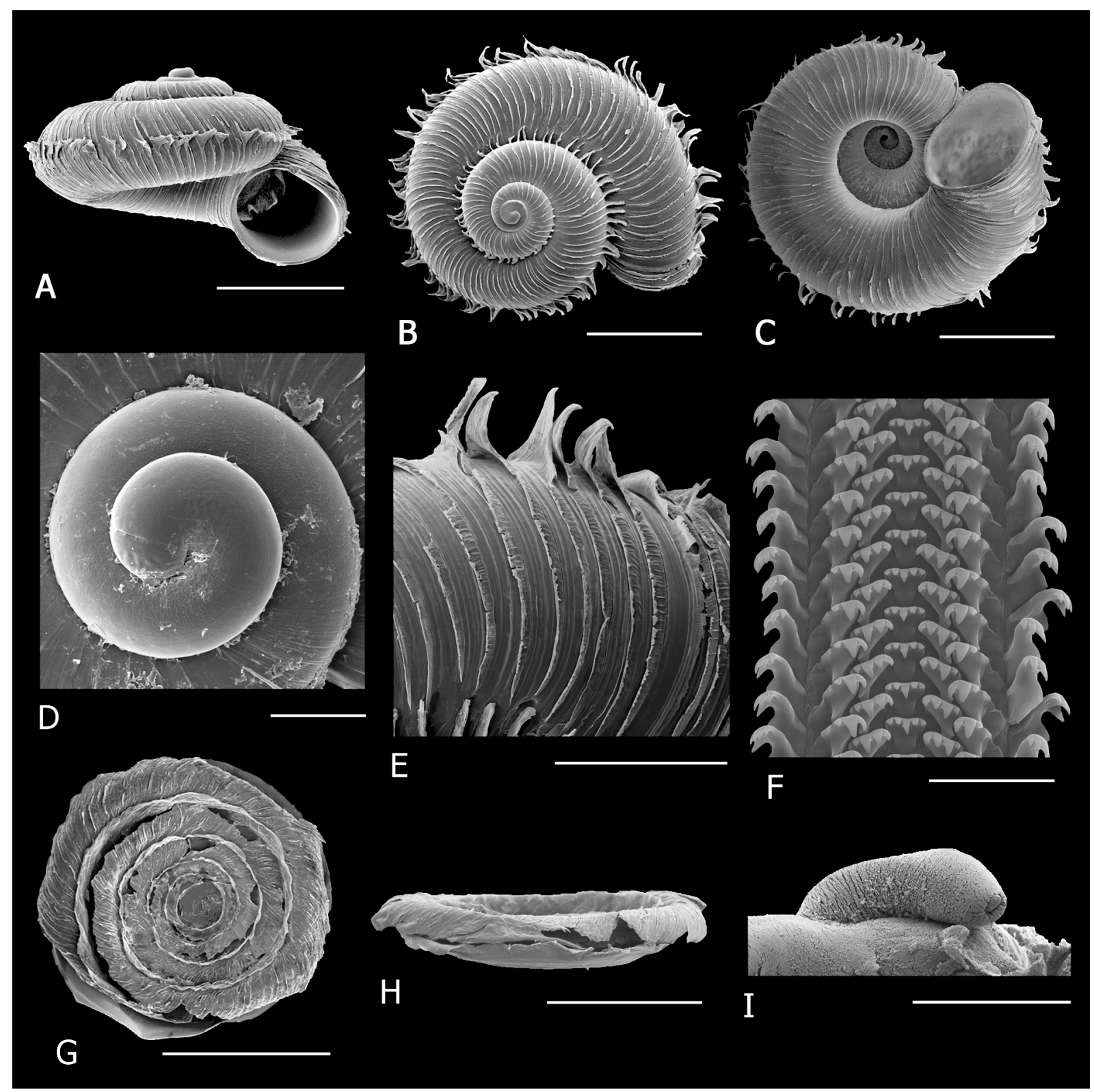

Fig. 13. Chondrocyclus silvicolus sp. nov. A. Aperture view (ELM D16963/T45). B. Dorsal view (ELM D16963/T45). C. Ventral view (ELM D16963/T45). D. Protoconch (ELM W3644/T46). E. Detail of axial lamellae of periostracum (ELM D16963/T45). F. Portion of radula (ELM D16963/T45). G-H. Operculum (ELM W3644/T46). I. Penis, lateral view (ELM W3644/T46). Scale bars: A-C = $2 \mathrm{~mm} ; \mathrm{D}=200 \mu \mathrm{m} ; \mathrm{E}, \mathrm{G}-\mathrm{I}=1 \mathrm{~mm} ; \mathrm{F}=50 \mu \mathrm{m}$. 


\section{Distribution and habitat}

Western Cape, from Storms River to Wilderness (Touw River) (Fig. 9). Indigenous Southern Cape Afrotemperate Forest and Western Cape Milkwood Forest (von Maltitz et al. 2003); in leaf-litter.

\section{Remarks}

The shell is less depressed than in the majority of other species of Chondrocyclus. Chondrocyclu. herberti sp. nov. has similar proportions, but the costae in C. silvicolus sp. nov. are not as widely spaced (Table 2) and have more pointed ends. C. silvicolus sp. nov. shells are also larger on average (Table 2). The two species inhabit different environmental conditions. C. silvicolus sp. nov. is a species of the ancient Southern Cape Afrotemperate forests, while $C$. herberti sp. nov. is adapted to drier conditions. Forest patches between the Baviaanskloof with $C$. herberti sp. nov. and the Southern Cape Afrotemperate forests where $C$. silvicolus sp. nov. occurs, have not been sampled.

Chondrocyclus convexiusculus has similar proportions and relatively widely spaced costae, but the ends of the flanges are produced into a narrow point. The operculum is less concave and the radula differs in having three rather than two large cusps on the second lateral tooth.

Chondrocyclus amathole sp. nov.

urn:1sid:zoobank.org:act:2B4E9251-C68B-450D-9EC6-820CCF66433E

Figs 9, 10D-E, 14

Chondrocyclus alabastris - Connolly 1939: 539.

\section{Diagnosis}

Shell small, very depressed, discoidal to lenticular; protoconch mammillate; periostracum with dense transverse costae developing at periphery broad quadrangular flanges; lamellate axial costae with dense axial riblets, rendering upper edge of each costa scalloped along its length; operculum duplex, exterior portion very shallowly concave to almost flat, multispiral lamella with fringe of very long bristles, fused at their tips, below main fringe is a second shorter fringe of loose bristles; umbilicus wide, exposing all the whorls; radula with two large cusps on second lateral tooth.

\section{Etymology}

Named after the Amathole Mountains, Eastern Cape, an area of natural and historic interest.

\section{Type material examined}

\section{Holotype}

SOUTH AFRICA - Eastern Cape - Amathole Mountains, Hogsback, downstream of Madonna and Child Waterfall, Southern Mistbelt forest; $32.6068^{\circ} \mathrm{S}, 26.9622^{\circ} \mathrm{E} ; 1061 \mathrm{~m}$ a.s.1.; 6 Apr. 2014; M. Cole, D. Herbert and L. Davis leg.; NMSA P0640/T4157. (Fig. 10D-E)

\section{Paratypes}

SOUTH AFRICA - Eastern Cape • 18 specimens; same collection data as for holotype; ELM W3812/ T59 21 specimens; Hogsback, downstream of Madonna and Child Waterfall; $32.6068^{\circ} \mathrm{S}, 26.9622^{\circ} \mathrm{E}$; 1061 m a.s.1.; 31 Dec. 2008; M. Bursey leg.; ELM D16944/T55 • 9 specimens; same collection data as for preceding; ELM W3629/T56 - 22 specimens; same collection data as for preceding; M. Cole leg., 13 Sep. 2012; ELM D17014/T57 • 6 specimens; same collection data as for preceding; ELM W3665/ T58 4 specimens; same collection data as for preceding; NMSA P0601/T4115 2 specimens; same collection data as for preceding; NHMUK 20120278 • 3 specimens; same collection data as for preceding; NMW.Z.2012.065.00008 • 3 specimens; same collection data as for preceding; RMNH MOL.33050 • 
COLE M.L., Revision of cyclophorid snails Chondrocyclus s.l.

3 specimens; Hogsback, forest above Hobbiton Camp, Southern Mistbelt forest; $32.5958^{\circ} \mathrm{S}, 26.9617^{\circ} \mathrm{E}$; 1253 m a.s.1.; 1 Dec. 2005; M. Bursey and V. Ndibo leg.; ELM W02966/T54 • 13 specimens; same collection data as for preceding; 13 Sep. 2012; ELM D17013/T60 13 specimens; same collection data as for preceding; ELM W3662/T61 • 28 specimens; same collection data as for preceding; 10 Jun. 2013; M. Cole leg.; ELM D17338/T63 • 7 specimens; same collection data as for preceding; 6 Apr. 2014; M. Cole, D. Herbert and L. Davis leg.; ELM W3811/T62 • 1 specimen; Kologha Forest, Evelyn valley, north side of Maden Dam, Murray's Krantz; 32.7257 S, 27.3078 E; 25 Apr. 1998; M. Bursey and N. Smith leg.; alive under a log; ELM D14417/T76 • 1 specimen; same collection data as for preceding; ELM W3693/T77 - 13 specimens; Isidenge, SE of Mount Kemp, harvested site, south-facing forest; $32.6885^{\circ} \mathrm{S}, 27.2783^{\circ} \mathrm{E} ; 1159$ m a.s.1.; 5 Apr. 2016; M. Cole leg.; ELM D18082/T198 • 4 specimens; same collection data as for preceding; ELM W03915/T196 • 23 specimens; Isidenge, Sandile's Rest, small patch of forest near base of Mount Kemp; $32.6614^{\circ}$ S, $27.3004^{\circ} \mathrm{E} ; 900$ m a.s.1.; 7 Apr. 2016; M. Cole leg.; ELM D18077/T200 • 8 specimens; same collection data as for preceding; ELM W03914/T195 •

3 specimens; Stutterheim, Kologha Forest, waterfall walk from picnic site; $32.5339^{\circ} \mathrm{S}, 27.4308^{\circ} \mathrm{E}$; 18 Jan. 2009; M. Cole leg.; ELM W3633/T64 - 5 specimens; same collection data as for preceding; 22 Dec. 2009; M. Cole and T. Pretorius leg.; ELM D16942/T65 • 1 specimen; same collection data as for preceding; ELM W03628/T66 • 2 specimens; same collection data as for preceding; 11 Dec. 2010; M. Cole leg.; ELM W3634/T67 • 4 specimens; Qacu forest; $32.4031^{\circ} \mathrm{S}, 27.4486^{\circ} \mathrm{E}$; 6 Apr. 2016; M. Cole leg.; ELM D18126/T201 • 5 specimens; same collection data as for preceding; ELM W03917/T197 • 5 specimens; Patchwood Farm, forest at source of Quanti River; $32.3924^{\circ} \mathrm{S}, 27.4470^{\circ} \mathrm{E} ; 1238 \mathrm{~m}$ a.s.l.; 18 Dec. 2012; M. and K. Cole leg.; ELM D17100/T80 - 3 specimens; Patchwood Farm, forest below (north of) house; $32.3875^{\circ} \mathrm{S}, 27.4501^{\circ} \mathrm{E}$; $1196 \mathrm{~m}$ a.s.1.; 6 Apr. 2016; M. Cole leg.; ELM D18140/T199 • 8 specimens; Fort Fordyce, south facing slope near top of pass; $32.6843^{\circ} \mathrm{S}, 26.4956^{\circ} \mathrm{E}$; $1110 \mathrm{~m}$ a.s.l.; 29 Dec. 2008; M. Cole leg.; ELM D16946/T68 • 19 specimens; same collection data as for preceding; ELM W3630/T69 • 36 specimens; same collection data as for preceding; 3 Jan. 2010; M. Cole leg.; ELM D16947/T70 • 12 specimens; same collection data as for preceding; ELM W3632/T71 • 1 specimen; same collection data as for preceding; 31 Dec. 2011; ELM D17005/T72 7 specimens; same collection data as for preceding; ELM W3631/T73 • 4 specimens; same collection data as for preceding; NHMUK 20120279 • 4 specimens; same collection data as for preceding; NMSA P0600/T4111 • 10 specimens; Fort Fordyce, south facing slope behind lookout; $32.6956^{\circ} \mathrm{S}, 26.4857^{\circ} \mathrm{E} ; 1120 \mathrm{~m}$ a.s.1.; 30 Dec. 2008; M. Cole leg.; ELM D16950/T74 5 specimens; same collection data as for preceding; 17 Jan. 2015; ELM D17860/T75 • 10 specimens; same collection data as for preceding; 1 Apr. 2016; ELM D18116/ T202 3 specimens; Kapp River, north bank, indigenous riverine forest on shady, south-facing slope; $33.4830^{\circ} \mathrm{S}, 27.0807^{\circ} \mathrm{E} ; 30$ Dec. 2002; M. Bursey; ELM W3694/T78 • 2 specimens; Beggars' Bush, $15 \mathrm{~km}$ E of Grahamstown, south facing slope; $33.2871^{\circ} \mathrm{E}, 26.6885^{\circ} \mathrm{E} ; 25 \mathrm{Feb} .2013$; M. Cole, G. Godfrey and S. Ritcher leg.; ELM D17289/T79.

\section{Other material examined}

SOUTH AFRICA - Eastern Cape - 5 specimens; Amathole Mountains: Hogsback, downstream of Madonna and Child Waterfall, Southern Mistbelt forest; $32.6068^{\circ} \mathrm{S}, 26.9622^{\circ} \mathrm{E} ; 1061 \mathrm{~m}$ a.s.1.; 25 Jan. 2002; M. Bursey leg.; ELM D13627 • 5 specimens; same collection data as for preceding; ELM W02834 6 specimens; Hogsback, forest above Hobbiton Camp, Southern Mistbelt forest; $32.5958^{\circ} \mathrm{S}$, 26.9617 ${ }^{\circ}$ E, 1253 m a.s.1.; 31 Dec. 2008; M. Bursey leg.; ELM D16945 • 14 specimens; Kologha Forest, near Stutterheim; $32.5333^{\circ}$ S, $27.3667^{\circ}$ E; 27 Nov. 1993; R. Scott leg.; ELM D14405 • 5 specimens; Stutterheim, Kologha Forest, forest drive near Protea Hill; 32.5558 ${ }^{\circ}$ S, 27.3175 E; 26 Jan. 2010; M. Cole leg.; ELM D16943 - 1 specimen; Stutterheim, Kologha Forest, waterfall walk from picnic site; $32.5339^{\circ} \mathrm{S}, 27.4308^{\circ} \mathrm{E}$; 30 Dec. 2012; M. Cole leg.; ELM D17623 • 3 specimens; Fort Fordyce, kloof with watercourse, running eastwards; $32.6704^{\circ} \mathrm{S}, 26.4851^{\circ} \mathrm{E}$; $1137 \mathrm{~m}$ a.s.1.; 29 Dec. 2008; M. Cole leg.; ELM D16949 - 3 specimens; Fort Fordyce, top of krantz near campsite; $32.6813^{\circ} \mathrm{S}, 26.4802^{\circ} \mathrm{E}$; 1134 m a.s.1.; 30 Dec. 2011; M. Cole leg.; ELM D16948 • 7 specimens; same collection data as for 
preceding; ELM W3631 - 2 specimens; Patchwood Farm, forest at source of Quanti River; $32.3924^{\circ} \mathrm{S}$, 27.4470 ${ }^{\circ}$ E, $1238 \mathrm{~m}$ a.s.1.; 18 Dec. 2012; M and K Cole leg.; ELM W03695 3 specimens; Patchwood Farm, forest below (north of) house; 32.3875 ${ }^{\circ} \mathrm{S}, 27.4501^{\circ} \mathrm{E}$ ); $1196 \mathrm{~m}$ a.s.l.; M. Cole leg.; 18 Dec. 2012 ELM D17107 • 5 specimens; same collection data as for preceding; ELM W03699.

\section{Description}

SHeLl (Fig. 14A-C). Small, very depressed, discoidal to lenticular, adult diameter 5.09-7.4 mm, height 2.34-3.92 mm, diameter:height 1.52-2.54 $(\mathrm{n}=68$ measured in three populations spanning the Amathole Mountains). Spire little exserted, apex mammillate. Embryonic shell (Fig. 14E) 2.25 whorls, microscopically malleate, junction between embryonic shell and teleoconch evident with development of costae on teleoconch. Teleoconch comprising 2.5 whorls, convex, very rapidly increasing, suture deeply impressed. Aperture circular, last whorl descending near aperture, peristome simple, continuous and free. Umbilicus wide, exposing all the whorls. Periostracum glossy, honey-brown and lacquerlike with dense lamellate costae at regular intervals, 73-167 $(\mathrm{n}=58)$ on last whorl, expanded into broad quadrangular flanges at periphery; lamellar blades ridged with dense axial riblets, rendering upper edge of each blade scalloped along its length; intervals between costae with about 6 microscopic axial threads. Shell translucent glossy honey-brown when fresh.

Living ANIMAL. Head, tentacles and snout dark grey, underside of foot creamy white.

Operculum (Fig. 14D, G). Duplex, very shallowly concave to almost flat; outer portion consists of multispiral lamella with five-six whorls; each step-shaped; height of lamellar blade very low; fringe of very long bristles, fused at their tips but not along their entire length, below main fringe is a second shorter fringe of relatively loose bristles, long outer fringe of each whorl fused to lamella of following whorl, but due to its long length, fringe forms convex curve between one whorl and next, height of fringe of each whorl exceeds height of lamellar blade, outermost lamellar fringe very long and is reflexed over peristome in life, but operculum can be withdrawn into aperture.

RadUla (Fig. 14F). Rachidian with five cusps, central cusp approx. twice length of outer cusps; first lateral tooth usually with three large cusps, small fourth cusp and a vestigial fifth, third cusp (from centre) largest; second lateral with two large cusps, second cusp (from centre) longer and broader than first, a very small third cusp and a vestigial fourth.

Penis (Fig. 14H-I). Shaft more or less cylindrical, slightly flattened, with prominent annular rugae, distal end smooth, intromittent organ short.

\section{Distribution and habitat}

Throughout the Amathole Mountains and extending eastwards towards the Kei River in isolated forest patches; also recorded at Beggars' Bush near Grahamstown and at Kap River Nature Reserve near the mouth of the Great Fish River (Fig. 9).

Amathole Mistbelt forest (Southern Mistbelt Forest group) (von Maltitz et al. 2003) and Great Fish Thicket (Kap River) (Hoare et al. 2006); in leaf-litter.

\section{Remarks}

The operculum of Chondrocyclus amathole sp. nov. is unique among all other Chondrocyclus species in its flatness, its long terminal fringe and relatively long secondary fringe below it and the low height of the multispiral lamellar blade. Chondrocyclus amathole sp. nov. was sister to C. alabastris and formed a well-supported clade (the Southern-Eastern Cape clade) with C. herberti sp. nov. and C. silvicolus sp. nov. (Fig. 1). The periostracal flanges of $C$. amathole sp. nov. were broad and quadrangular while 
in the other three species in its clade, the flanges were pointed. In this feature, C. amathole sp. nov. resembled species in the Eastern Clade, but differed from species in the latter clade in all other diagnostic morphological features, i.e., single row of flanges at periphery, unique operculum, radula with two large cusps on second lateral tooth, cyclindrical penis (Cole et al. 2019).

The Amathole Range is an outlier of the southern end of the Drakensberg, isolated by the valleys of the Great Fish and Great Kei Rivers (Stuckenberg 1962) and is known for endemicity of many low-vagility forest-dependent taxa, including molluscs (Connolly 1939; Herbert \& Moussalli 2010; unpublished data), forest-floor spiders (Griswold 1985), velvet worms (Daniels \& Ruhberg 2010), harvestmen (de Bivort \& Giribet 2010) and two frogs. Furthermore, populations of velvet worms in close geographic proximity are genetically discrete, suggesting that the historic contractions and expansions of forests

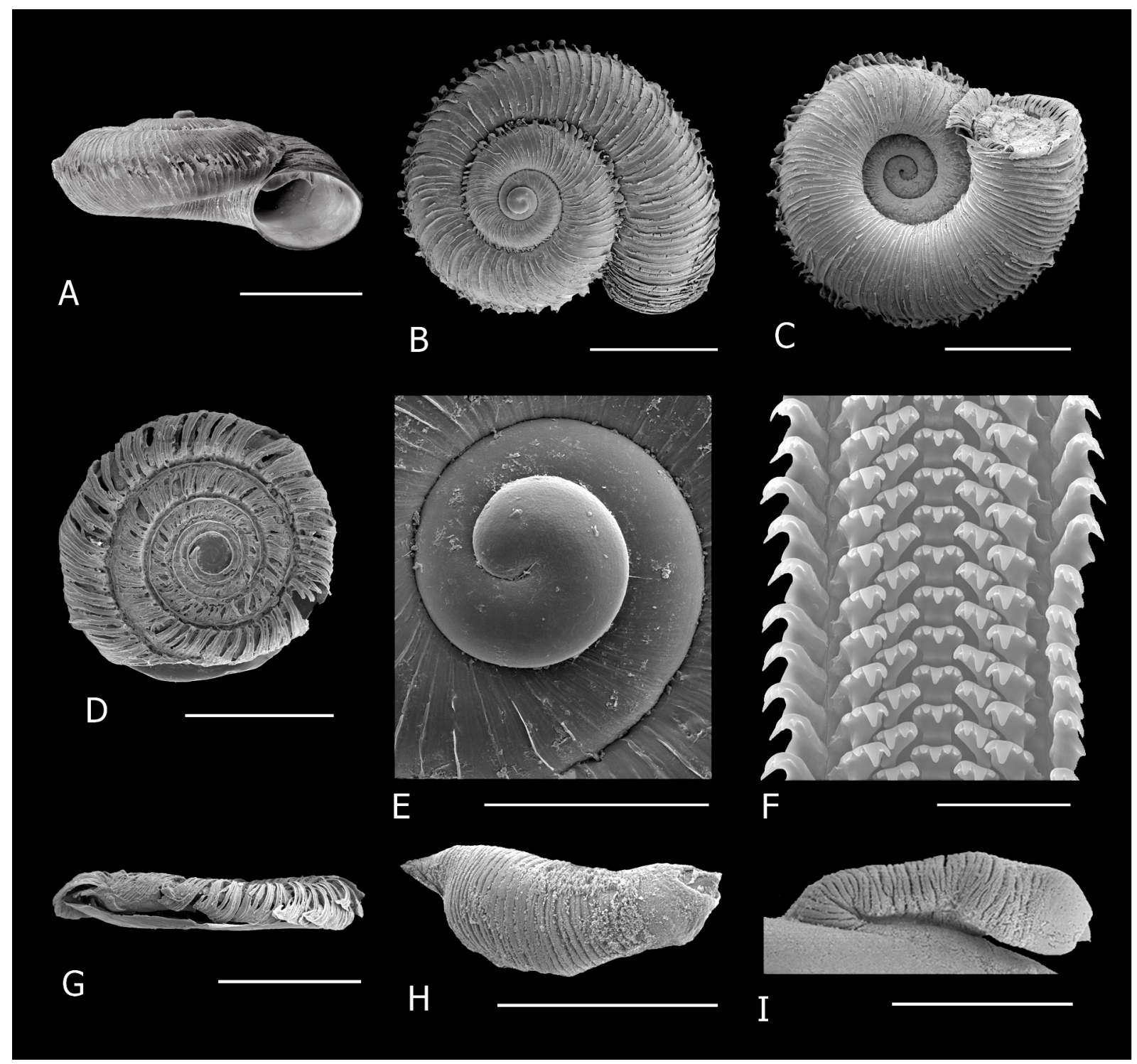

Fig. 14. Chondrocyclus amathole sp. nov. A. Aperture view (ELM W3629/T56). B. Dorsal view (ELM W3629/T56). C. Ventral view (ELM W2966/T54). D, G. Operculum (ELM W2966/T54). E. Protoconch (ELM W3812/T59). F. Portion of radula (ELM W3628/T66). H. Penis, dorsal view (ELM W3628/T66). I. Penis, lateral view (ELM W3632/T71). Scale bars: A-C $=2 \mathrm{~mm} ; \mathrm{D}, \mathrm{G}-\mathrm{I}=1 \mathrm{~mm} ; \mathrm{E}=500 \mu \mathrm{m} ; \mathrm{F}=$ $50 \mu \mathrm{m}$. 
in this region left a significant and complex impact on the phylogeography of low-vagility organisms (Daniels et al. 2017).

Chondrocyclus amathole sp. nov. has been recorded in two localities geographically separated from the mistbelt forests of the Amatholes, indicative of past vegetation shifts. The population of C. amathole sp. nov. in the outlying forest patch, Beggars' Bush near Grahamstown, was separated from populations of the sister species, C. alabastris on the opposite ridge, by a dry intervening valley. Beggars' Bush is currently separated from the Amathole mountains by the dry Great Fish River basin although both regions are designated Amathole Mistbelt in certain classification systems and distinguished from other Southern Mistbelt forests (von Maltitz et al. 2003). The presence of C. amathole sp. nov. near the mouth of the Great Fish River suggests a link between the coast and the Amathole Mountains, a pattern also demonstrated in other taxa (e.g., Streptocarpus (Hughes et al. 2005)). The Great Fish River basin has been identified as an area of persistence of thicket during the contractions of the LGM (Potts et al. 2012). The distribution pattern in this eastern subclade of the Southern-Eastern Cape clade (i.e., C. alabastris and C. amathole sp. nov.) is mirrored by rhytidid snails (Herbert \& Moussalli 2010, 2016).

\section{Chondrocyclus trifimbriatus Connolly, 1929}

Figs 15, 16A

Chondrocyclus trifimbriatus Connolly, 1929: 241, pl. xiv, figs 35-39 (type loc.: Karkloof, bush behind Karkloof Falls [Falcon]).

Chondrocyclus trifimbriatus - Connolly 1939: 538. — Herbert \& Kilburn 2004: 92.

\section{Diagnosis}

Shell small, depressed, lenticular; periostracum with dense axial costae developing five rows of flanges on last whorl: just below suture, at periphery, around umbilicus and two weaker rows on either side of periphery; operculum duplex, exterior portion shallowly concave with step-shaped multispiral lamella terminating in a long solid fringe reflexed over peristome; radula with three large cusps on second lateral tooth, cusps of rachidian, first and second lateral teeth fairly uniform in size; penis flattened dorsoventrally and laterally expanded on left side from about midway down the shaft, intromittent organ relatively long.

\section{Etymology}

The specific name is derived from the Latin 'tres', meaning 'three', and 'fimbriae', meaning 'fringe', with reference to the three spiral cords of compacted flange-like bristles on the last whorl.

\section{Type material examined}

\section{Holotype}

SOUTH AFRICA - KwaZulu-Natal [Natal] • Karkloof, Natal; presented by W. Falcon; NHMUK 1928.3.16.5. (Fig. 15A)

\section{Other material examined}

SOUTH AFRICA - KwaZulu-Natal • 6 specimens; Karkloof River valley, southwest of 'The Start'; $29.3150^{\circ} \mathrm{S}, 30.250^{\circ} \mathrm{E} ; 1350 \mathrm{~m}$ a.s.l.; W. Falcon coll.; NMSA A8000 2 specimens; Nkandla Forest Reserve, Chibini area, scarp forest; $28.7227^{\circ} \mathrm{S}, 31.1282^{\circ} \mathrm{E} ; \pm 1200 \mathrm{~m}$ a.s.1.; 20 Oct. 2003; D. Herbert, M. Bursey and T. Nangammbi leg.; under logs and in leaf litter; NMSA W1115 1 specimen; Entumeni Forest, $7 \mathrm{~km}$ west of Eshowe; $28.8852^{\circ} \mathrm{S}, 31.3797^{\circ} \mathrm{E}$; $680 \mathrm{~m}$ a.s.1.; 29 Oct. 2010; M. Cole leg.; ELM D16966 1 specimen; same collection data as for preceding; ELM W3692 1 specimen; same collection 
COLE M.L., Revision of cyclophorid snails Chondrocyclus s.l.

data as for preceding; 13 Jan. 2010; ELM D17003 • 3 specimens; same collection data as for preceding; ELM W03661.

\section{Description}

Shell (Fig. 15A-C). Small, depressed, lenticular, adult diameter 3.9-4.37 mm (4.37-5.32 mm Entumeni population), height 1.95-2.66 mm (2.39-2.86 mm Entumeni population), diameter:height 1.65-2.0 (1.62-2.02 mm Entumeni population) $(\mathrm{n}=5$ C. trifimbriatus from type locality; $\mathrm{n}=6$ Entumeni population). Spire not much raised, protoconch sub-mammillate (Connolly 1929). Embryonic shell two whorls, microscopically malleate, junction between embryonic shell and teleoconch evident with development of costae on teleoconch. Teleoconch comprising 2.75 whorls, convex, rapidly increasing, suture deeply impressed. Aperture circular, last whorl descending near aperture, peristome simple, continuous and free. Umbilicus wide and deep, exposing all the whorls. Periostracum glossy, honeybrown and lacquer-like with dense lamellate axial costae at regular intervals, approx. 150-155 ( $\mathrm{n}=4)$ on last whorl in specimens from the type locality, but varying between populations (see Remarks below), expanded into quadrangularly-shaped flanges at periphery, immediately below the suture and around the umbilicus, the row at the periphery the strongest, and with two less prominent rows of lower-standing flanges on either side of periphery. Shell translucent, glossy, corneous yellow-brown when fresh.

LiVING ANIMAL. Creamy white with slight pigmentation on tentacles.

Operculum (Fig. 15D, F). Duplex, lamella of outer multispiral portion with 4.25 whorls, step-shaped; on outer surface of lamellar blade a long, solid fringe curves upwards and then outwards forming a groove between fringe and lamellar blade, spanned by a very loose network of bristles; a very short solid horizontal fringe emanates just below main fringe; upper edge of lamella thin and projects above fringe in side view; outer surface of lamellar blade tuberculate at high magnification.

Radula (Fig. 15E). Rachidian with five cusps, approx. equivalent length; first and second lateral teeth similar, each with five cusps, first three cusps approx. equivalent in size, the fourth very small and the fifth (from centre) vestigial; cusps increase in size very slightly from central tooth outwards, but there is not a large difference in size between cusps.

Penis (Fig. 15G). flattened dorsoventrally and laterally expanded on left side from about midway down the shaft, with numerous annular rugae, smooth distal end narrows, intromittent organ relatively long.

\section{Distribution and habitat}

Originally known only from Karkloof River Valley, downstream of Karkloof Falls, but the species appears to have disappeared from the Karkloof vicinity (Fig. 16A). Specimens recently discovered at Entumeni and Nkandla forests are considered here to be C. trifimbriatus based on comparison with type material.

No habitat data available for original specimens, but indigenous Eastern Mistbelt Forest (von Maltitz et al. 2003) occurs in the Karkloof vicinity. Recently collected specimens occur in Scarp forests (Entumeni) and Mistbelt/Scarp (Nkandla) in leaf litter.

\section{Remarks}

There are morphological differences between populations from different localities. Specimens from Entumeni (Fig. 15B-C) lack the spiral row of flanges just below the suture and the weak row below the periphery. Specimens from Nkandla also bear fewer spiral cords than C. trifimbriatus: there is a spiral cord just below suture and one between periphery and umbilicus but the weak cords on either side of periphery are absent. Although not many specimens were available to measure (four from Karkloof, 


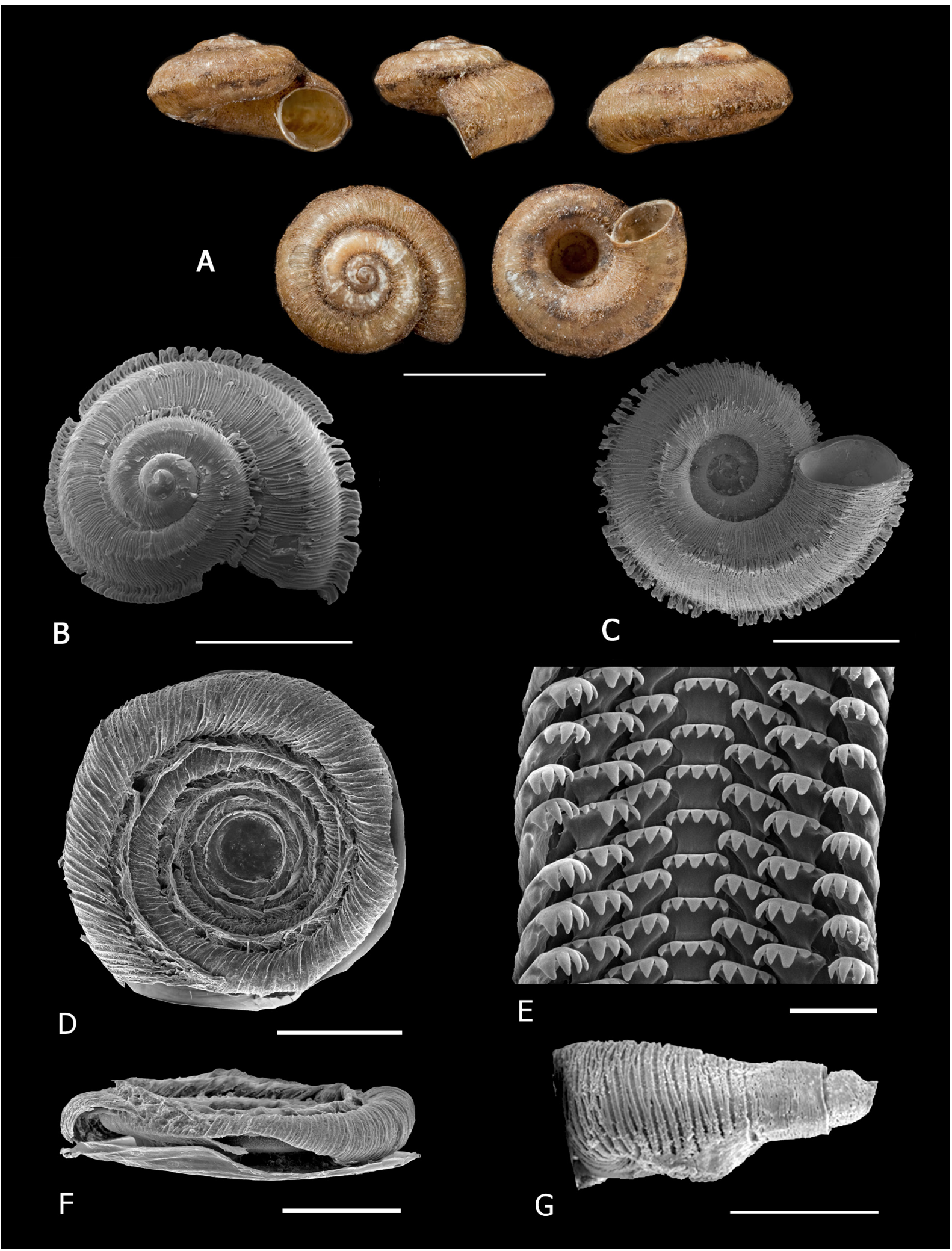

Fig. 15. Chondrocyclus trifimbriatus Connolly, 1929. A. Holotype (NHMUK 1928.3.16.5). B. Dorsal view (ELM W3661). C. Ventral view (ELM W3661). D, F. Operculum (NMSA A8000). E. Portion of radula (ELM W3661). G. Penis, dorsal view (NMSA W1115). Scale bars: $A=3 \mathrm{~mm} ; \mathrm{B}-\mathrm{C}=2 \mathrm{~mm}$; , $\mathrm{F}-\mathrm{G}=500 \mu \mathrm{m} ; \mathrm{E}=20 \mu \mathrm{m}$. 
COLE M.L., Revision of cyclophorid snails Chondrocyclus s.l.
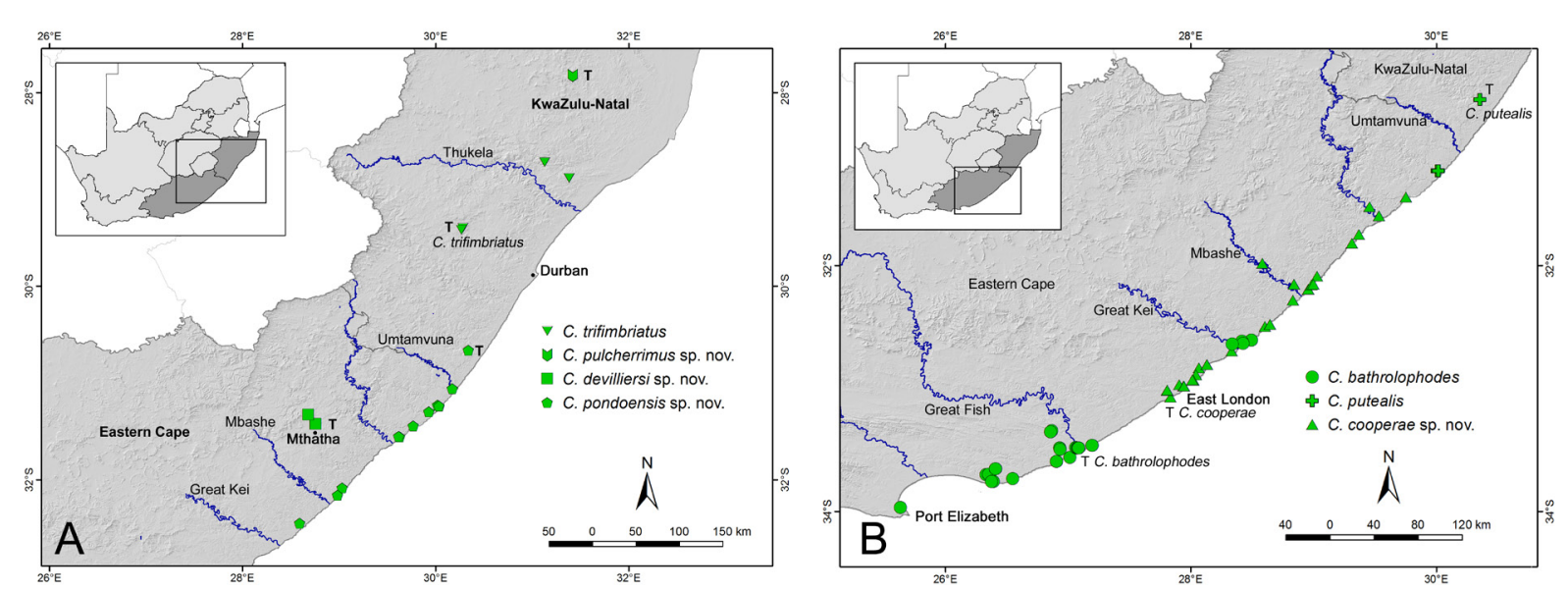

Fig. 16. Distribution map of Chondrocyclus species in the Eastern clade. A. Species in KwaZulu-Natal and the eastern half of the Eastern Cape, on the coast and extending inland. B. Species on the Eastern Cape coast. Note that the range of $C$. pondoensis sp. nov. overlaps with that of $C$. putealis Connolly, 1939 and $C$. cooperae sp. nov. T indicates type localities. Major cities and rivers are labelled.

six from Entumeni and two from Nkandla), D:H ratio is similar throughout but the axial costae on last whorl are more dense in Entumeni specimens (approx. 200) and less dense in Nkandla specimens (117) compared to 150-155 in Karkloof specimens. The opercula of specimens from Entumeni and Nkandla are similar to the operculum of C. trifimbriatus from the type locality (Fig. 15D). The radulae of all populations agree with the descriptions and figure of Connolly $(1929,1939)$.

Few specimens were available for study since they seemed to be very rare in the two forests where they were found, and more sampling from these and other forests in north-central KwaZulu-Natal are required to resolve more conclusively whether $C$. trifimbriatus occurs throughout the region or whether there may be additional narrow-range species. The only localities represented in the molecular study were Entumeni and Ngome (considered to contain a separate species, C. pulcherrimus sp. nov.). The highly fragmented forests of north-central Kwazulu-Natal contain many examples of species, in unrelated taxa, with extremely narrow distributions (e.g., Huber 2003; Herbert \& Kilburn 2004; Tilbury \& Tolley 2009) suggesting that the observed morphological differences between populations may indicate undescribed species.

Chondrocyclus pondoensis sp. nov. urn:lsid:zoobank.org:act:3913F1CE-3CB5-4B2F-AA60-BB811D014A4B

Figs 10G-H, 16A, 17

\section{Diagnosis}

Shell small, depressed, lenticular; protoconch not mammillate; periostracum with dense, erect, transverse costae, expanded to form five spiral rows of raised flanges: a paddle-shaped row at periphery, a row of well-developed quadrangularly-shaped flanges around umbilicus and above periphery and a row of lower semi-circular flanges below suture; operculum duplex, lamella forming outer portion of operculum step shaped and terminating in a long solid fringe, portion above fringe consists of a lattice-like network of interwoven bristles some fused to fringe, projecting well above fringe and sloping inward towards centre; umbilicus wide and deep, exposing all the whorls; radula with three large cusps on second lateral tooth, cusps of rachidian, first and second lateral teeth fairly uniform in size; penis flattened dorsoventrally and laterally expanded about midway down the shaft, intromittent organ relatively long. 


\section{Etymology}

Named for the distribution of the species, centered around the Pondoland region.

\section{Type material examined}

\section{Holotype}

SOUTH AFRICA - KwaZulu-Natal • Port Shepstone area, Marble Delta, Hlokohloko Valley, middle section, riverine/scarp forest; $30.6619^{\circ} \mathrm{S}, 30.3342^{\circ} \mathrm{E} ; 175 \mathrm{~m}$ a.s.l.; Feb. 2012; J. Harvey leg.; in leaflitter; NMSA P0643/T4160. (Fig. 10G-H)

\section{Paratypes}

SOUTH AFRICA - KwaZulu-Natal -8 specimens; same collection data as for holotype, NMSA W8763/T4161 • 2 specimens; same collection data as for preceding; NHMUK 20160079 1 specimen; same collection data as for preceding; RMNH.MOL.338286 • 8 specimens; Port Shepstone area, Marble Delta, Hlokohloko Valley, middle section, riverine/scarp forest; $30.6608^{\circ} \mathrm{S}, 30.3325^{\circ} \mathrm{E} ; 188 \mathrm{~m}$ a.s.l.; in leaf-litter, Feb. 2012; J. Harvey leg.; in leaf-litter; NMSA W8733/T4162 • 2 specimens; same collection data as for preceding; NMW.Z.2016.003.00002 - 2 specimens; Port Shepstone area, Marble Delta, Hlokohloko Valley, middle section, riverine/scarp forest; $30.6622^{\circ} \mathrm{S}, 30.3386^{\circ} \mathrm{E} ; 145 \mathrm{~m}$ a.s.1.; Feb. 2012; J. Harvey leg.; in leaf-litter; NMSA W8765/T4171 • 1 specimen; same collection data as for preceding; RMNH.MOL.338287 • 17 specimens; Port Shepstone, Simuma area, Hlokohloko valley, riverine/scarp forest; $30.6631^{\circ} \mathrm{S}: 30.3368^{\circ} \mathrm{E}$; ca $150-200 \mathrm{~m}$ a.s.1.; 5 Mar. 2011; Herbert and Davis leg.; in leaf-litter; NMSA W7844/T4144 7 specimens; Umtamvuna Nature Reserve, Port Edward, Old Pont Road, $2.5 \mathrm{~km}$ upstream of mouth; $31.0603^{\circ} \mathrm{S}, 30.1725^{\circ} \mathrm{E}$; $56 \mathrm{~m}$ a.s.1.; 13 Apr. 2011; M. Cole, D. Herbert, L. Davies and R. Daniels leg.; ELM D16940/T113 - 5 specimens; same collection data as for preceding; ELM W03627/T114 - 2 specimens; same collection data as for preceding; NHMUK 20120271. - Eastern Cape 1 specimen; Mtentu, north bank; $31.2400^{\circ} \mathrm{S}, 30.0367^{\circ} \mathrm{E} ; 20$ May 2005; M. Bursey and V. Ndibo leg.; ELM W03027/T109 • 2 specimens; Mtentu, north bank, $1.5 \mathrm{~km}$ upstream, inlet to first waterfall, on east side of inlet; $31.2389^{\circ} \mathrm{S}, 30.0340^{\circ} \mathrm{E}$; 13 Jan. 2012; M. Cole leg.; ELM D17406/T110 • 1 specimen; same collection data as for preceding; ELM W03602/T111 1 specimen; Mtentu, north bank, $3 \mathrm{~km}$ upstream of mouth, inlet to second waterfall, west side of inlet; $31.2295^{\circ} \mathrm{S}, 30.0182^{\circ} \mathrm{E} ; 43 \mathrm{~m}$ a.s.l.; 12 Jan. 2012; M. Cole leg.; ELM W03603/T112 • 1 specimen; Mkambati Nature Reserve, 'Superbowl' forest, $5 \mathrm{~km}$ upstream of Msikaba mouth, east side of Msikaba River; $31.2978^{\circ} \mathrm{S}, 29.9293^{\circ} \mathrm{E}$; 3 May 2004; M. Bursey leg.; in leaf-litter; ELM D14256/T107 • 2 specimens; same collection data as for preceding; 18 May 2005; ELM D15585/T108 • 1 specimen; Mbotyi, Drewes camp, east of village, dune forest at east end of beach, just before cliffs; $31.4432^{\circ} \mathrm{S}, 29.7686^{\circ} \mathrm{E}$; $13 \mathrm{Jan} .2003$; M Bursey leg.; ELM D14396/T106 1 specimen; Ntafufu, below lodge, west bank, $2 \mathrm{~km}$ upstream of mouth; $31.5514^{\circ} \mathrm{S}$, 29.6175² E; 24 Apr. 2005; D.-J. Hodgkinson leg.; ELM D15532/T101 • 2 specimens; Ntafufu, east bank, $1.5 \mathrm{~km}$ upstream of mouth; $31.5565^{\circ} \mathrm{S}, 29.6261^{\circ} \mathrm{E}$; 24 Apr. 2005; M. Bursey leg.; ELM D15531/T102 • 2 specimens; Mpame forest; $32.0856^{\circ}$ S, $29.0306^{\circ}$ E; 19 Feb. 2009; M. Cole leg.; ELM D16941/T105 • 2 specimens; Xora, Kumqolo Forest, west bank of Xora River opposite mangrove swamp; $32.1589^{\circ} \mathrm{S}$, 28.9848 E); 25 Oct. 2005; M. Bursey leg.; ELM D15537/T103 • 1 specimen; same collection data as for preceding; 13 Aug. 2011; M. Cole leg.; ELM W03663/T104 • 1 specimen; Manubi forest; $32.4426^{\circ}$ S, 28.6130 E; 3 Oct. 2017; M. Cole leg.; ELM W04034/T203.

\section{Description}

SHELl (Fig. 17A-C). Small, depressed, lenticular, adult diameter 4.59-6.18 mm, height 2.42-3.42 mm, diameter:height 1.59-2.00 $(\mathrm{n}=19)$. Spire not much raised, protoconch not mammillate. Embryonic shell just over 1.5 whorls, microscopically malleate, junction between embryonic shell and teleoconch not particularly distinct, initially costae weak, becoming well developed after about a quarter of a whorl (Fig. 17D). Teleoconch comprising 2.75 whorls, moderately convex, rapidly increasing, suture deeply impressed. Aperture circular, last whorl descending near aperture, peristome simple, continuous and free. Umbilicus wide and deep, exposing all the whorls. Periostracum glossy, honey-brown and 
lacquer-like with dense lamellate costae at regular intervals, approx. 154-184 ( $\mathrm{n}=14)$ on last whorl, expanded into five spiral rows of flanges: a paddle-shaped row at periphery, a row of well-developed quadrangularly-shaped flanges around umbilicus and above periphery and a row of lower semi-circular flanges below suture; flanges bear numerous axial riblets visible at very high magnification (Fig. 17E); intervals between costae with microscopic axial threads. Shell translucent, glossy, corneous yellowbrown when fresh.

LIVING ANIMAL. Creamy white with slight pigmentation on tentacles.

OperCulum (Fig. 17G-H). Duplex, outer portion consists of multispiral lamella with 4.5-5 whorls; lamellar blade high, stepped, long fringe emanates near top of vertical portion of blade; blade projects high above fringe and slopes inward towards centre, upper portion of lamellar blade consists of latticelike network of interwoven bristles, some bristles connected to main fringe so there is no groove between fringe and lamellar blade (Fig. 17G); at the growing edge the top portion of lamellar blade is more or less square, not sloping, becoming arrow shaped below fringe (Fig. 17H). Outer lamellar fringe reflexed over peristome preventing animal withdrawing into shell.

RAdULA (Fig. 17F). Rachidian with five cusps, central one slightly longer; first and second laterals each with three large cusps, a smaller fourth and a vestigial fifth, cusps increase in size very slightly from central tooth outwards, but there is not a large difference in size between cusps.

PENIS (Fig. 17I-J). Expanded towards distal end, intromittent organ relatively long.

\section{Distribution and habitat}

Known primarily from near the coast between Xora in Transkei and Umtamvuna in southern KwazuluNatal, and also recorded inland in the Port Shepstone area (ca $200 \mathrm{~m}$ a.s.l.) (Fig. 16A). (The Transkei is the area of the Eastern Cape Province between the Kei and Umtamvuna Rivers.)

Indigenous Scarp Forest of the Pondoland Gorge and Transkei Coastal Scarp subtypes (von Maltitz et al. 2003), adjacent to rivers, in leaf litter. Scarp forests are a forest type occurring on south- and east-facing hills and gorges of the first plateau escarpment (300-1100 m) and unique to the east of South Africa.

\section{Remarks}

Morphologically, C. pondoensis sp. nov. resembles C. trifimbriatus in features of the periostracum, operculum and radula. The position of spiral rows of flanges is equivalent in C. pondoensis sp. nov. and C. trifimbriatus specimens from the type locality. The radulae have teeth with cusps relatively uniform in size. The operculum of C. pondoensis sp. nov. is flatter than that of coastal species of Chondrocyclus. However, it is distinguished from that of C. trifimbriatus by the outer lamellar blade projecting high above the fringe and sloping towards the centre and a well-developed lattice of interwoven bristles joining the lamellar blade to the fringe (Fig. 17G). Other species bearing a lattice of interwoven bristles at the top edge of lamellar blade, fused with the main fringe are the coastal C.putealis Conolly, 1939, C. bathrolophodes Conolly, 1929 and C. cooperae sp. nov. but these species have a relatively deep operculum.

In the molecular study, C. pondoensis sp. nov. did not appear related to C. trifimbriatus or to any other lineages (Cole et al. 2019).

In coastal areas of Transkei where C. pondoensis sp. nov. is sympatric with C. putealis and C. cooperae sp. nov. specimens appeared to be scarce and patchily distributed, while at localities in southern KwaZulu-Natal (Umtamvuna Nature Reserve and Hlokohloko valley inland of Port Shepstone) where C. pondoensis sp. nov. was the only Chondrocyclus species recorded, specimens appeared to be common. 


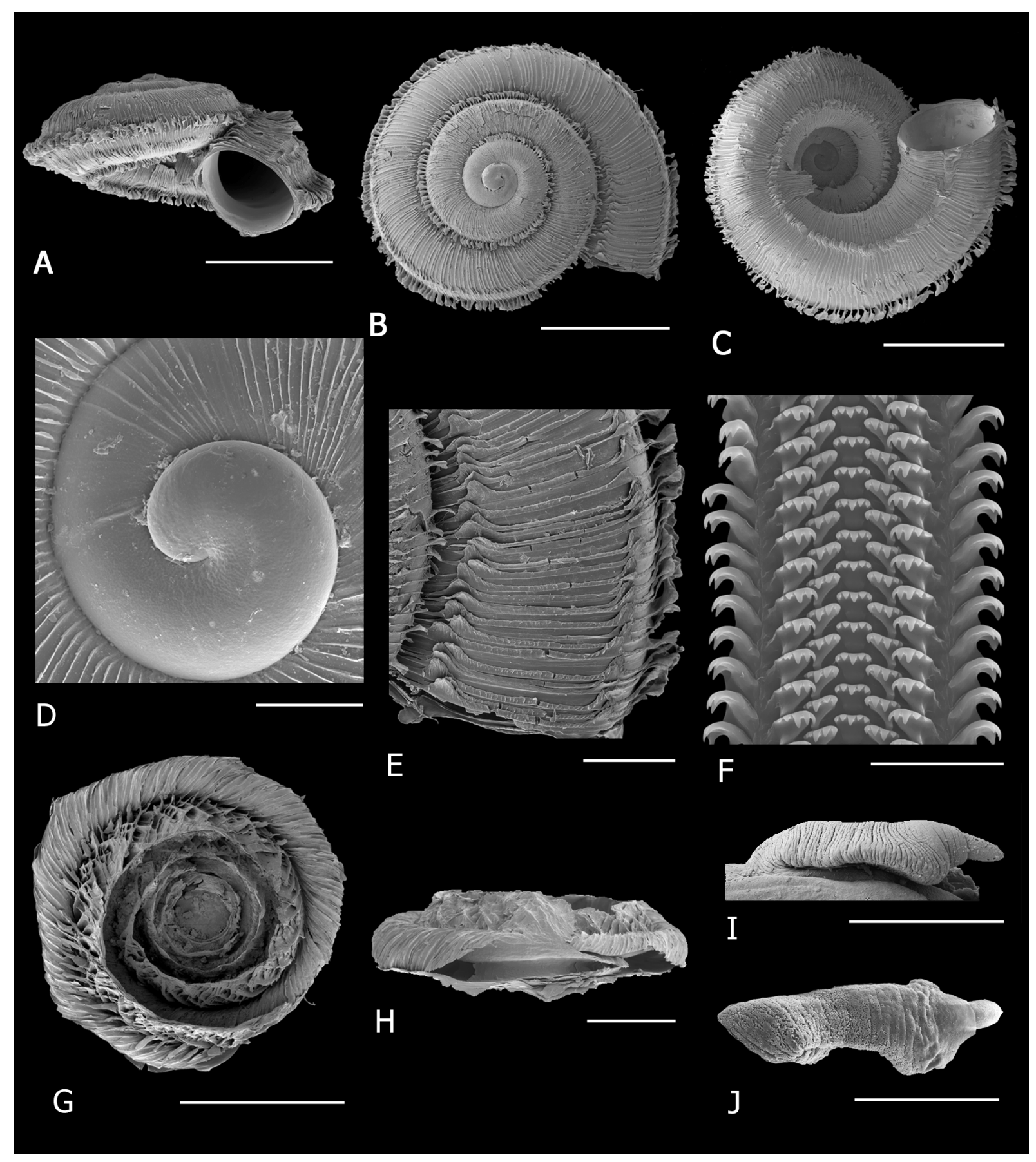

Fig. 17. Chondrocyclus pondoensis sp. nov. A. Aperture view (ELM W3602/T111). B. Dorsal view (ELM W3627/T114). C. Ventral view (ELM W3627/T114). D. Protoconch (NMSA W8733). E. Detail of axial lamellae of periostracum (ELM W3627/T114). F. Portion of radula (ELM W3627/T114). G-H. Operculum (ELM W3627/T114). I. Penis, lateral view (NMSA W7844/T4144). J. Penis, dorsal view (ELM W3627/T114). Scale bars: A-C $=2 \mathrm{~mm} ; \mathrm{D}=200 \mu \mathrm{m} ; \mathrm{E}, \mathrm{H}=500 \mu \mathrm{m} ; \mathrm{F}=50 \mu \mathrm{m} ; \mathrm{G}, \mathrm{I}-\mathrm{J}=1 \mathrm{~mm}$. 
COLE M.L., Revision of cyclophorid snails Chondrocyclus s.l.

\section{Chondrocyclus devilliersi sp. nov. urn:1sid:zoobank.org:act:3F362337-8D53-4763-A67D-9852125813E1}

Figs 10I, L, 16A, 18

Chondrocyclus putealis - Herbert \& Kilburn 2004: 91.

\section{Diagnosis}

Shell small, depressed, lenticular; protoconch not mammillate; periostracum with widely spaced axial costae developing at the periphery broad rounded flanges, semi-circular in shape; operculum duplex, exterior portion very shallowly concave to almost flat, with step-shaped multispiral lamella terminating in a short fringe of fused bristles.

\section{Etymology}

Named for Div DeVilliers whose unwaivering dedication to nature conservation in the Eastern Cape province, and the Transkei in particular, has helped preserve the remaining forests and their biota.

\section{Type material examined}

\section{Holotype}

SOUTH AFRICA - Eastern Cape - Nqadu Forest, 19 km north of Mthatha, Transkei Mistbelt Forest; $31.4173^{\circ} \mathrm{S}, 28.7320^{\circ} \mathrm{E}$; 17 Jan. 2017, M. Cole and R. Cawood leg.; in leaf litter; NMSA P1141/T4312. (Fig. 10I-L)

\section{Paratypes}

SOUTH AFRICA - Eastern Cape 44 specimens; same collection data as for holotype; ELM D18243/ T173 33 specimens; same collection data as for preceding; ELM W3962/T174 • 4 specimens; same collection data as for preceding; NMSA P0641/T4158 • 1 dry specimen; same collection data as for preceding; NHMUK 20180581 - 3 specimens in ethanol; same collection data as for preceding; NHMUK 20180582 • 1 specimen; same collection data as for preceding; NMW.Z.2019.004.00001 • 2 specimens in ethanol; same collection data as for preceding; NMW.Z.2019.004.00002 1 specimen; same collection data as for preceding; NMW.Z.2019.004.00003 - 3 specimens in ethanol; same collection data as for preceding; RMNH.MOL.340754 - 1 specimen; same collection data as for preceding; RMNH.MOL.340755 - 11 specimens; Nqadu Forest, 19 km north of Mthatha, Transkei Mistbelt Forest; $31.4241^{\circ} \mathrm{S}, 28.7547^{\circ} \mathrm{E} ; 16$ Apr. 2015; M. and K. Cole leg.; in leaf litter; ELM D17922/ T116 4 specimens; same collection data as for preceding; ELM W3861/T117 • 2 specimens; same collection data as for preceding; 26 Jan. 2013; M. Cole, V. Ndibo and T. Morgenthal leg.; ELM D17147/ T115 • 1 specimen; same collection data as for preceding; ELM W3716/T167 • 1 specimen; Nqadu Forest, north of Mthatha, Southern Mistbelt Podocarpus forest; $31.4278^{\circ} \mathrm{S}, 28.7520^{\circ} \mathrm{E} ; 12$ May 2001; D. Herbert leg.; in leaf litter; NMSA V9111/T4110 • 4 specimens; Bele Forest, $32 \mathrm{~km}$ NNW of Mthatha, northern end of Langeni escarpment, Transkei Mistbelt Forest; $31.3279^{\circ} \mathrm{S}, 28.6790^{\circ} \mathrm{E}$; 18 Jan. 2017; M. Cole and R. Cawood leg.; in leaf litter; ELM D18238/T175 • 12 specimens; same collection data as for preceding; ELM W3949/T176 • 2 specimens; same collection data as for preceding; NMSA P1126/ T4295.

\section{Description}

SHELl (Fig. 18A-C). Small, depressed, lenticular, adult diameter 5.01-6.01 mm, height 2.59-3.17 mm, diameter:height 1.70-2.16 $(\mathrm{n}=16)$. Spire not much raised, apex almost flat. Embryonic shell (Fig. 18DE) nearly 2.25 whorls, microscopically malleate, junction between embryonic shell and teleoconch evident with development of costae on teleoconch. Teleoconch comprising 2.75 whorls, convex, rapidly increasing, suture deeply impressed. Aperture circular, last whorl descending near aperture, peristome simple, continuous and free. Umbilicus wide and deep, exposing all the whorls. Periostracum glossy, 


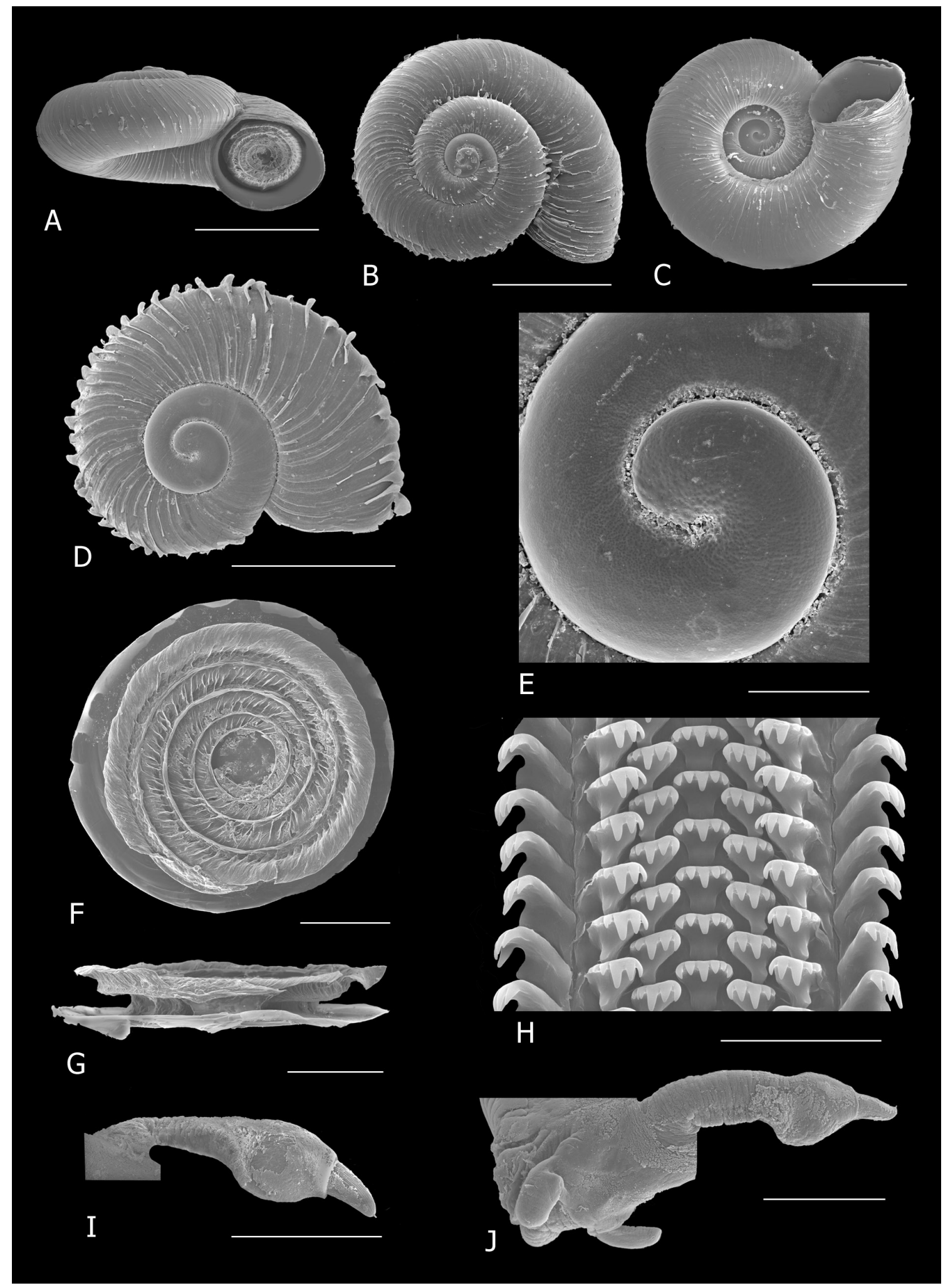

Fig. 18. Chondrocyclus devilliersi sp. nov. A. Aperture view (ELM W3962/T174). B. Dorsal view (ELM W3962/T174). C. Ventral view (ELM W3962/T174). D. Dorsal view of juvenile shell (NMSA V9111/ T4110). E. Protoconch (NMSA V9111/T4110). F-G. Operculum (ELM W3962/T174). H. Portion of radula (ELM W3962/T174). I. Penis, lateral view (ELM W3962/T174). J. Penis, dorsal view ((ELM W3962/T174). Scale bars: A-C $=2 \mathrm{~mm} ; \mathrm{D}, \mathrm{I}-\mathrm{J}=1 \mathrm{~mm} ; \mathrm{E}=200 \mu \mathrm{m} ; \mathrm{F}-\mathrm{G}=500 \mu \mathrm{m} ; \mathrm{H}=50 \mu \mathrm{m}$. 
honey-brown and lacquer-like with widely spaced lamellate axial costae at regular intervals, 65-77 $(n=4)$ on last whorl, expanded into a single row of semi-circular flanges at periphery (Fig. 18D). Shell translucent, glossy, corneous yellow-brown when fresh.

OperCulum (Fig. 18F-G). Duplex, outer portion slightly concave; lamella of outer multispiral portion with 4.5 whorls, step-shaped; upper edge of lamella thin and projects slightly above fringe. Radula (Fig. 18H). Rachidian with five cusps, central cusp approx. twice length of outer two on each side; first and second lateral teeth similar but second is slightly larger, each with four cusps and a vestigial fifth; first three cusps gradually increasing in size from centre outwards and fourth very small.

PENIS (Fig. 18I-J). Shaft dorsoventrally flattened, with lateral expansions of shaft on both sides towards distal end but more prominent on left, with numerous annular rugae, smooth distal end narrower, intromittent organ relatively long.

\title{
Distribution and habitat
}

Known only from two forests, Nqadu approx. $20 \mathrm{~km}$ north of Mthatha and Bele to the north-west. Transkei Mistbelt Forest (von Maltitz et al. 2003), in leaf litter (Fig. 16A).

\section{Remarks}

Chondrocyclus devilliersi sp. nov. has several unique morphological features and in the molecular analyses it was not closely related to other species of Chondrocyclus in the Eastern Clade. Although the majority of adult specimens are worn even when collected alive and display few features of the periostracum, the fresh juveniles reveal that there is only one row of expanded flanges around the periphery of the shell (Fig. 18D) and not multiple spiral rows on the body whorl as in other members of the Eastern clade. This resembles the pattern in C. convexiusculus and species in the Southern-Eastern Cape clade.

The radula resembles that of the coastal taxa C. bathrolophodes, C. putealis and C. cooperae sp. nov. with varying sizes of cusps, while the flat operculum is quite unlike the deeply concave operculum of these species.

\author{
Chondrocyclus pulcherrimus sp. nov. \\ urn:lsid:zoobank.org:act:F19B8F07-075C-4A7F-BD19-BB875003E7D0
}

Figs 10J-K, 16A, 19

\section{Diagnosis}

Shell very small, very depressed, discoidal; periostracum with very dense axial costae developing at the periphery a row of quadrangularly-shaped flanges and several spiral rows of semicircular flanges above and below this; operculum duplex, exterior saucer-shaped portion with step-shaped multispiral lamella terminating in a long solid fringe reflexed over peristome; radula with three large cusps on second lateral tooth, cusps on rachidian uniform in size; penis flattened dorsoventrally and laterally expanded on left side from about midway down the shaft.

\section{Etymology}

The specific name is derived from the Latin 'pulcherrimus', meaning 'most beautiful', with reference to the ornate periostracum with very dense axial lamellae and a larger number of spiral rows of flanges than any other species. 


\section{Type material examined}

\section{Holotype}

SOUTH AFRICA - KwaZulu-Natal - Ngome Forest, west of Nongoma, Southern Mistbelt forest; $27.8245^{\circ} \mathrm{S}, 31.4191^{\circ} \mathrm{E} ; 1136 \mathrm{~m}$ a.s.1.; 19 Jan. 2010; M. and K. Cole leg.; in leaf litter; NMSA W9272/ T3075. (Fig. 10J-K)

\section{Paratypes}

SOUTH AFRICA - KwaZulu-Natal • 66 specimens; same collection data as for holotype; ELM D16939/T118 • 1 specimen; same collection data as for holotype; ELM W3626/T119 • 5 specimens; same collection data as for holotype; NHMUK 20120281 • 3 specimens in ethanol; same collection data as for holotype; NMW.Z.2019.004.00009 - 2 dry specimens; same collection data as for holotype; NMW.Z.2019.004.00008 • 4 specimens; same collection data as for holotype; RMNH MOL.330504 • 11 specimens; Ngome Forest, mist-belt Podocarpus forest; $27.8250^{\circ} \mathrm{S}, 31.4183^{\circ} \mathrm{E} ; 1200 \mathrm{~m}$ a.s.l.; 2 Dec. 1998; Herbert, Seddon and Tattersfield leg.; in leaf-litter beneath Trichocladus grandilflorus; NMSA V7103/T4112 - 24 specimens; Ngome Forest, mist-belt Podocarpus forest; $27.8250^{\circ} \mathrm{S}$, $31.4833^{\circ}$ E; 1100 m a.s.l.; 2 Dec. 1998; Herbert, Seddon and Tattersfield leg.; in leaf-litter; NMSA V8530/T4113.

\section{Description}

SHELl (Fig. 19A-C). Small, very depressed, discoidal, adult diameter 3.50-4.85 mm, height 1.38$2.56 \mathrm{~mm}$, diameter:height 1.87-2.54 $(\mathrm{n}=22)$. Spire almost flat with sometimes only protoconch projecting (Fig. 19A), suture deeply impressed. Embryonic shell (Fig. 19D) just over two whorls, sculptured with pock marks, junction between embryonic shell and teleoconch not particularly distinct, with weak costae at first, becoming stronger. Teleoconch comprising two whorls, rapidly increasing, suture deeply impressed. Aperture circular, last whorl descending near aperture, peristome simple, continuous and free. Umbilicus very wide, exposing all the whorls (Fig. 19C). Periostracum glossy, light yellowishbrown and lacquer-like, with very dense lamellate axial costae at regular intervals, approx. 300 on last whorl (300 and 340 in Fig. 19B and A, respectively), developing at the periphery quarangularly-shaped flanges, their expanded distal ends fused to form a solid fringe (Fig. 19E); above periphery are four-five spiral rows of flanges and six-seven rows below it spiraling into umbilicus, height of flanges forming spiral rows varies; row of flanges below suture forms a channel (see Fig. 19B,D); intervals between costae smooth. Shell pale, corneous and translucent when fresh.

Operculum (Fig. 19G-I). Duplex, outer portion consists of multispiral lamella with about 4.5 whorls, each step-shaped; at the growing edge the top of lamellar blade slopes down at an angle then curves under the step formed by the previous whorl and is thinner and more or less perpendicular where it is attached to the disc; very long fringe of fused bristles emanates from near base of vertical portion of step and curves upwards and then outwards forming a deep furrow between fringe and lamellar blade, spanned by a few bristles; a very short solid horizontal fringe emanates just below main fringe; top edge of lamella projects above level of fringe; fringe of each whorl fused to lamella of following whorl; outermost lamellar fringe very long and reflexed over peristome.

RAdULA (Fig. 19F). Rachidian with five cusps of approx. equivalent length; first lateral tooth with three cusps of approx. equivalent length and a very small fourth; second lateral tooth with three cusps of approx. equivalent length and two vestigial outer cusps; teeth do not differ much in size.

PENIS (Fig. 19J-K). flattened dorsoventrally and laterally expanded on left side from about midway down the shaft, with numerous annular rugae, smooth distal end occupies about one quarter of shaft. 
COLE M.L., Revision of cyclophorid snails Chondrocyclus s.l.

\section{Distribution and habitat}

Known only from Ngome Forest, KwaZulu-Natal. Indigenous Eastern Mistbelt Forest (von Maltitz et al. 2003) with large trees, south-facing; in leaf-litter (Fig. 16A).

\section{Remarks}

The very dense costae of the periostracum of C. pulcherrimus sp. nov. and large number of spiral rows of flanges, as well as the flat spire, immediately distinguish this species from all other species of Chondrocyclus.

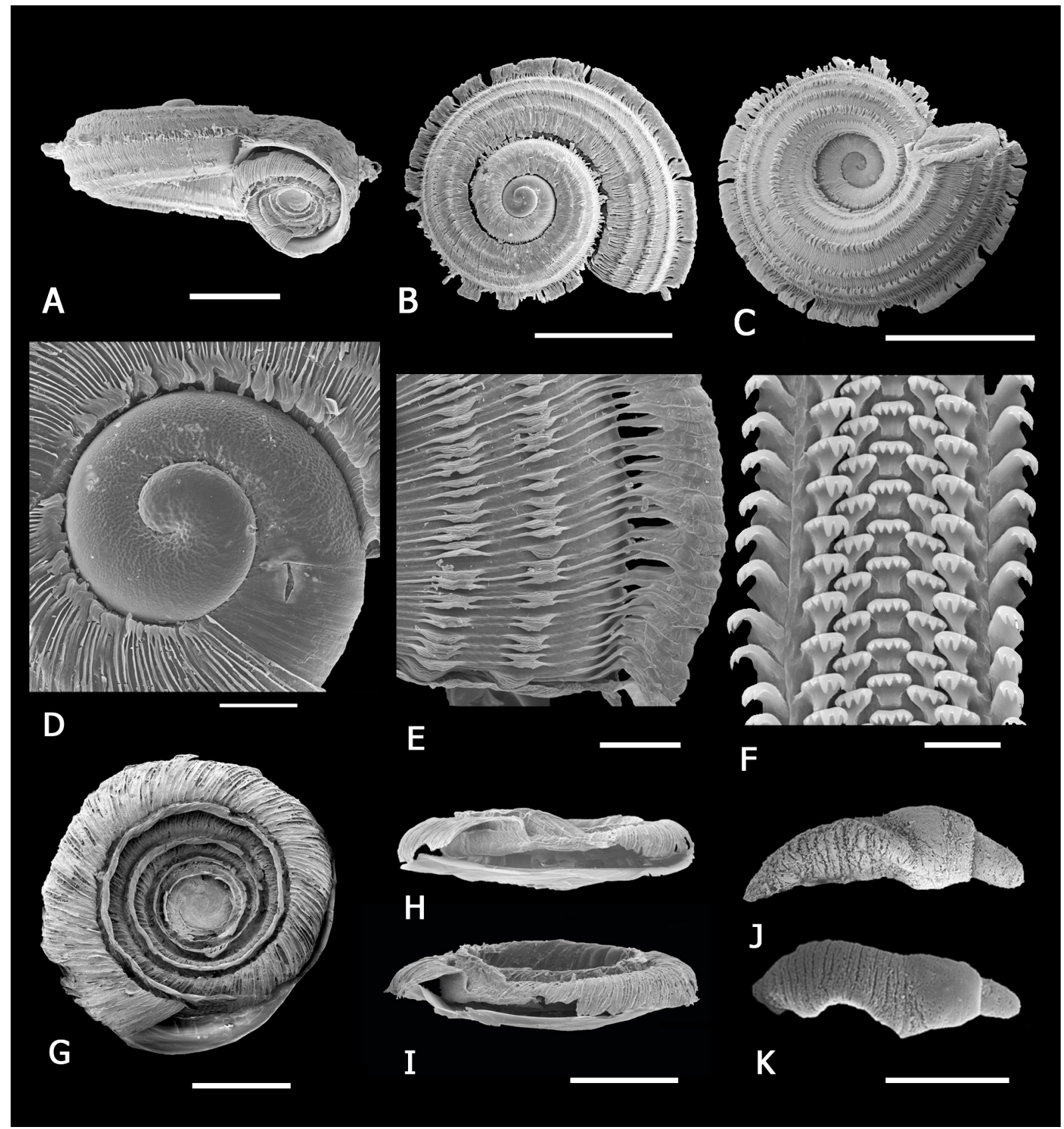

Fig. 19. Chondrocyclus pulcherrimus sp. nov. A-K. ELM W3626/T119. A. Aperture view. B. Dorsal view. C. Ventral view. D Protoconch. E. Detail of axial lamellae of periostracum. F. Portion of radula. G-I. Operculum. J. Penis, lateral view. K. Penis, dorsal view. Scale bars: A-C =2 mm; D-E = $200 \mu \mathrm{m}$; $\mathrm{F}=20 \mu \mathrm{m} ; \mathrm{G}-\mathrm{K}=500 \mu \mathrm{m}$. 
Chondrocyclus pulcherrimus sp. nov. resembles C. trifimbriatus in features of the operculum, radula, penis and the rough texture of the protoconch. The operculum is similar to that of C. trifimbriatus, but the fringe emanates from near the bottom of the vertical portion of the stepped lamellar blade forming a deep groove while in C. trifimbriatus it emanates from near the top of the blade and there is a very shallow groove between the fringe and lamella.

The Ngome Forest is 3360 ha and much of the forest is protected in the Ntendeka Wilderness Area. Chondrocyclus pulcherrimus sp. nov. is locally very common unlike C. trifimbriatus which appears to be rare in all populations sampled.

Chondrocyclus bathrolophodes Connolly, 1929

Figs 16B, 20-21

Chondrocyclus bathrolophodes Connolly, 1929:239, pl. xiv, figs 30-34 (type loc.: Kowie East [Kincaid]).

Chondrocyclus bathrolophodes - Connolly 1939: 538. — Herbert \& Kilburn 2004: 92.

\section{Diagnosis}

Shell small, depressed, lenticular; periostracum with dense axial costae expanded into three spiral rows of flanges on last whorl: at periphery, around umbilicus and below suture; costae and flanges bear numerous tiny vertical ridges; operculum duplex, exterior portion with cup-shaped multispiral lamella with horizontal shelf of interwoven bristles spiralling up on inside of cup, fused to a very long, loose fringe reflexed over peristome; radula with three large cusps on second lateral tooth; penis flattened dorsoventrally with lateral expansions of shaft towards distal end, more prominent on left side.

\section{Type material examined}

\section{Holotype}

SOUTH AFRICA - Eastern Cape • Cape Province, Kowie East; NHMUK 1928.3.16.4. (Fig. 20A)

\section{Other material examined}

SOUTH AFRICA - Eastern Cape 10 specimens; Port Elizabeth, Baakens River; $33.967^{\circ} \mathrm{S}, 25.333^{\circ} \mathrm{E}$; Sep. 1998; ex Durban Museum; NMSA V6683 - 28 specimens; Alexandria Forest, Langebos, vicinity of forest station; $33.6533^{\circ} \mathrm{S}, 26.4083^{\circ} \mathrm{E}$; 2 Feb. 2009; M. Cole leg.; ELM D15950 • 7 specimens; same collection data as for preceding; top of ridge with beacon tower; $33.6951^{\circ} \mathrm{S}, 26.3542^{\circ} \mathrm{E} ; 24 \mathrm{Nov}$. 2006; M. Bursey leg.; ELM D14938 • 1 specimen; same collection data as for preceding; 23 Nov. 2009; M. Cole leg.; ELM D16960 • 27 specimens; same collection data as for preceding; ELM W03658 • 32 specimens; same collection data as for preceding; vicinity of hikers huts; $33.6991^{\circ} \mathrm{S}, 26.3636^{\circ} \mathrm{E}$; 21 Nov. 2009; M. Cole leg.; ELM D16924 • 14 specimens; same collection data as for preceding; ELM W03617 • 5 specimens in ethanol; same collection data as for preceding; NHMUK 20120274 • 5 specimens; Cannon Rocks, dune thicket; $33.7333^{\circ} \mathrm{S}, 26.5500^{\circ} \mathrm{E}$; 2 Feb. 2009; M. Cole leg.; in leaf litter; ELM D16002 - 12 specimens; Port Alfred, coastal forest east of Kowie River mouth, dune forest behind tall dunes; $33.5919^{\circ} \mathrm{S}, 26.9047^{\circ} \mathrm{E}$; 26 Nov. 2006; M. Bursey and T. Moffat leg.; in leaf litter; ELM D14998 • 50 specimens; same collection data as for preceding; 12 Oct. 2009; M. Cole leg.; ELM D16922 • 32 specimens; same collection data as for preceding; ELM W03616 3 specimens in ethanol; same collection data as for preceding; NHMUK 20120273 • 2 specimens in ethanol; same collection data as for preceding; NMW.Z.2012.065.00005 - 66 specimens; same collection data as for preceding; 6 Apr. 2011; R. Daniels leg.; ELM D16923 - 12 specimens; Tharfield, east bank of Riet River, dune forest; $33.5589^{\circ} \mathrm{S}, 27.0150^{\circ} \mathrm{E}$; 30 Jan. 2008; M. Cole leg.; ELM D15882 • 2 specimens; The Glen on Pig Island Farm on Kleinemonde River; $33.4833^{\circ} \mathrm{S}, 26.9333^{\circ} \mathrm{E}$; 12 Jan. 2007; M. Bursey leg.; ELM W03192 • 22 specimens; same collection data as for preceding; ELM D15394 • 25 specimens; same 
COLE M.L., Revision of cyclophorid snails Chondrocyclus s.l.

collection data as for preceding; 1 Feb. 2009; M. Cole leg.; ELM D16150 • 2 specimens; same collection data as for preceding; ELM W03635 -8 specimens; Kap River Nature Reserve, south bank, thin strip of forest at base of dry north-facing cliffs; $33.4821^{\circ} \mathrm{S}, 27.0758^{\circ} \mathrm{E} ; 35 \mathrm{~m}$ a.s.1.; 21 Dec. 2002; M. Bursey leg.; ELM D16925 • 1 specimen; Kap River Nat. Res., north bank, in ravine; $33.4812^{\circ} \mathrm{S}, 27.0873^{\circ} \mathrm{E}$; $42 \mathrm{~m}$ a.s.1.; 30 Dec. 2002; M. Bursey leg.; leaf litter; ELM D16926 3 specimens; same collection data as for preceding; 13 May 2011; M. Cole leg.; ELM D16927 • 6 specimens; same collection data as for preceding; ELM W03618 32 specimens; Gess farm, indigenous forest in north-facing ravine leading into Kap river; $33.4803^{\circ} \mathrm{S}, 27.0634^{\circ} \mathrm{E}$; $31 \mathrm{~m}$ a.s.l.; 28 May 2011; M. Cole leg.; ELM D16928 • 24 specimens; same collection data as for preceding; ELM W03619 • 84 specimens; Kap River, north bank, indigenous riverine forest on shady, south-facing slope; $33.4830^{\circ} \mathrm{S}, 27.0807^{\circ} \mathrm{E} ; 9$ Jun. 2012; M Cole leg.; ELM D17002 • 1 specimen; Kei River, tributary on west bank 6 km upstream of mouth, forest on steep slope, south facing; $32.6300^{\circ} \mathrm{S}, 28.3483^{\circ} \mathrm{E}$; 11 Feb. 2006; M. Bursey leg.; ELM D14990 • 7 specimens; Umthombe Kei Resort, west bank of Kei River, $6 \mathrm{~km}$ upstream of mouth, watercourse with steep banks, rocky in places; $32.6313^{\circ} \mathrm{S}, 28.3469^{\circ} \mathrm{E} ; 42 \mathrm{~m}$ a.s.l.; 7 May 2018; M. Cole leg.; ELM D18355 10 specimens; same collection data as for preceding; ELM W04053 • 1 specimen; Qolora estuary, west bank, steep slope with Strelitzia nicolai; $32.6333^{\circ}$ S, $28.4277^{\circ}$ E; 14 m a.s.1.; 4 May 2006; D.-J. Hodgkinson leg.; ELM D14853 • 6 specimens; same collection data as for preceding; 11 Jun. 2018; M. Cole leg.; ELM W04071 • 5 specimens; Kobonqaba, coastal forest on east side of mouth; $32.6058^{\circ} \mathrm{S}$, $28.4933^{\circ}$ E; 17 m a.s.1.; 23 Apr. 2015; M. Cole leg.; ELM D17932 3 specimens; same collection data as for preceding; ELM W03868.

\section{Description}

SHell (Fig. 20A-D). Small, depressed, lenticular, adult diameter 5.32-6.16 mm, height 2.76-3.45 mm, diameter:height 1.73-2.00 $(\mathrm{n}=25)$. Spire depressed, each whorl just rising above the next, apex almost flat (Fig. 20A-B). Embryonic shell (Fig. 21A) 1.75 whorls, microscopically malleate, roughest in centre, junction between embryonic shell and teleoconch evident with appearance of a few weak axial costae, but not sharply demarcated. Teleoconch comprising 2.75 whorls, moderately convex, rapidly increasing, suture deeply impressed. Aperture circular, last whorl descending near aperture, peristome simple, continuous and free. Umbilicus wide and deep, exposing all the whorls (Fig. 20D). Periostracum glossy, honey-brown and lacquer-like with dense lamellate costae at regular intervals, 92-127 ( $\mathrm{n}=24)$ on last whorl, expanded into quadrangularly-shaped flanges at periphery, forming a distinct peripheral cord, as well as a row of shorter semicircular flanges below the suture and around the umbilicus (Fig. 20A-D); flanges bear numerous axial riblets visible at very high magnification (Fig. 21B); intervals between costae with microscopic axial threads (Fig. 20B). Shell translucent honey-brown when fresh.

Living ANIMAL. Head, tentacles and snout dark grey, underside of foot creamy white.

OperCulum (Fig. 21C-E). Duplex, outer multispiral portion with 5.5 whorls forming a strongly concave cup, upper edge of lamellar blade thickened, forming a horizontal shelf of interwoven bristles spiralling up the inside of the cup; in the outermost whorl the latter is loosely connected to a very long fringe reflexed over peristome and preventing operculum being withdrawn into shell; in earlier whorls this fringe is not visible and appears fused with the lamella; surface of lamella of last whorl tuberculate at high magnification.

RadULA (Fig. 21F). Rachidian with five cusps, central cusp approx. twice length of outer two on each side; first and second lateral teeth similar but second is larger, each with four cusps and a vestigial fifth; first three cusps gradually increasing in size from centre outwards and fourth very small.

PENIS (Fig. 21G-H). Shaft dorsoventrally flattened, with lateral expansions of shaft on both sides towards distal end but more prominent on left, with numerous annular rugae, distal end bulbous and smooth, intromittent organ exserted, but not elongated. 


\section{Distribution and habitat}

Endemic to Eastern Cape coast with a disjunct distribution, occurring between Port Elizabeth and Great Fish River (recorded up to $9 \mathrm{~km}$ inland) and between Great Kei and Kobonqaba River (recorded up to $6 \mathrm{~km}$ inland) (Fig. 16B).

Albany Dune Strandveld on coastal dunes at Port Alfred (Mucina et al. 2006), Alexandria Forest with large trees, classified as Southern Coastal Forest (Mucina \& Geldenhuys 2006) or Albany Coastal Forest (von Maltitz et al. 2003), Albany Thicket (Kowie Thicket and Buffels Thicket) (Hoare et al. 2006) and Eastern Cape Dune Forest (von Maltitz et al. 2003); in leaf-litter.

\section{Remarks}

Chondrocyclus bathrolophodes is similar to C. putealis (differences are discussed under the latter species) in periostracal ornamentation, operculum, radula and penis.

Specimens recorded in the vicinity of the Kei and Kobonqaba Rivers would have been difficult to identify on morphological grounds alone, but the molecular phylogeny shows unambiguously that the

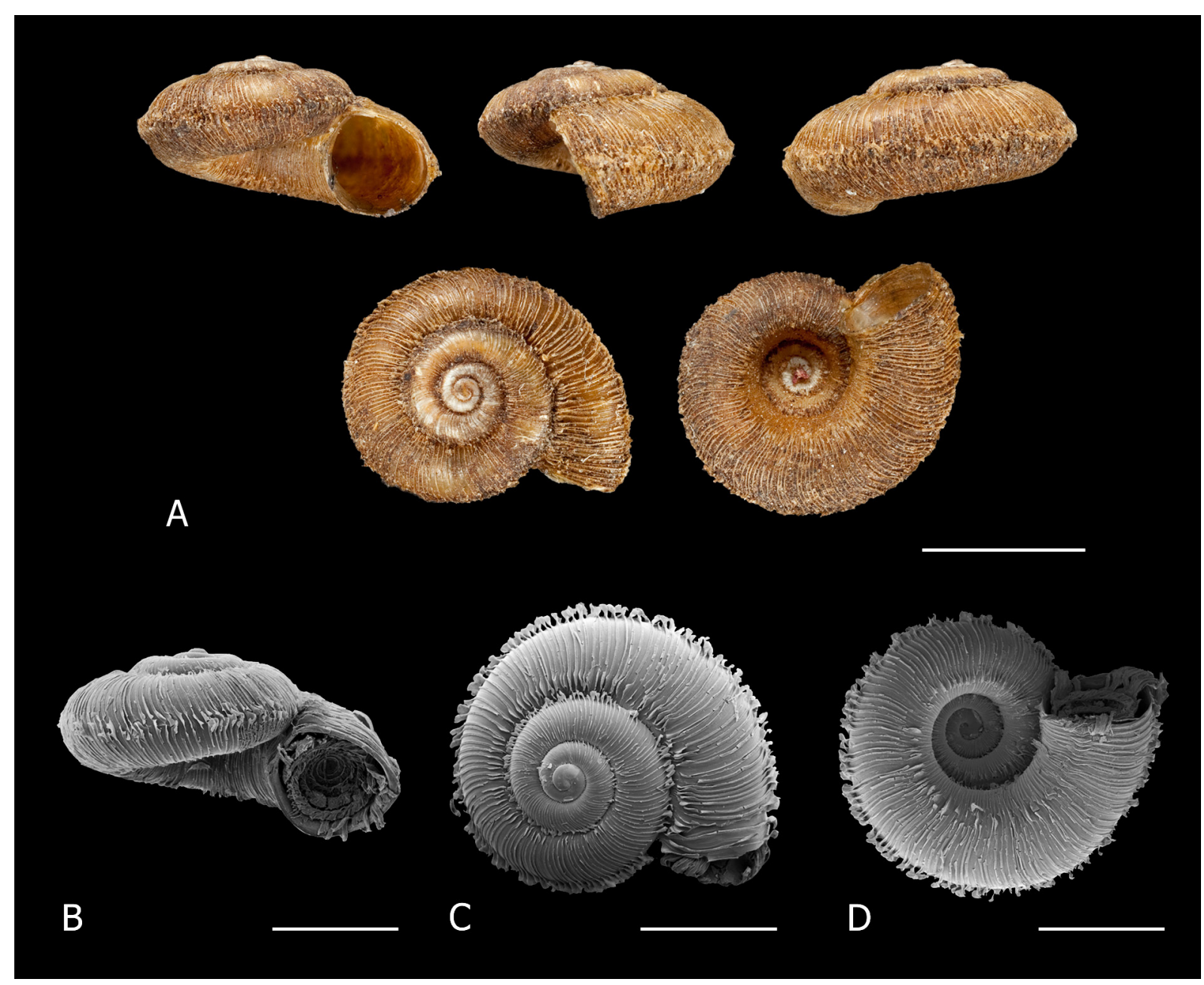

Fig. 20. Chondrocyclus bathrolophodes Connolly, 1929. A. Holotype (NHMUK 1928.3.16.4). B-D. ELM W3616. B. Aperture view. C. Dorsal view. D. Ventral view. Scale bars: A= $3 \mathrm{~mm}$; B-D = $2 \mathrm{~mm}$. 


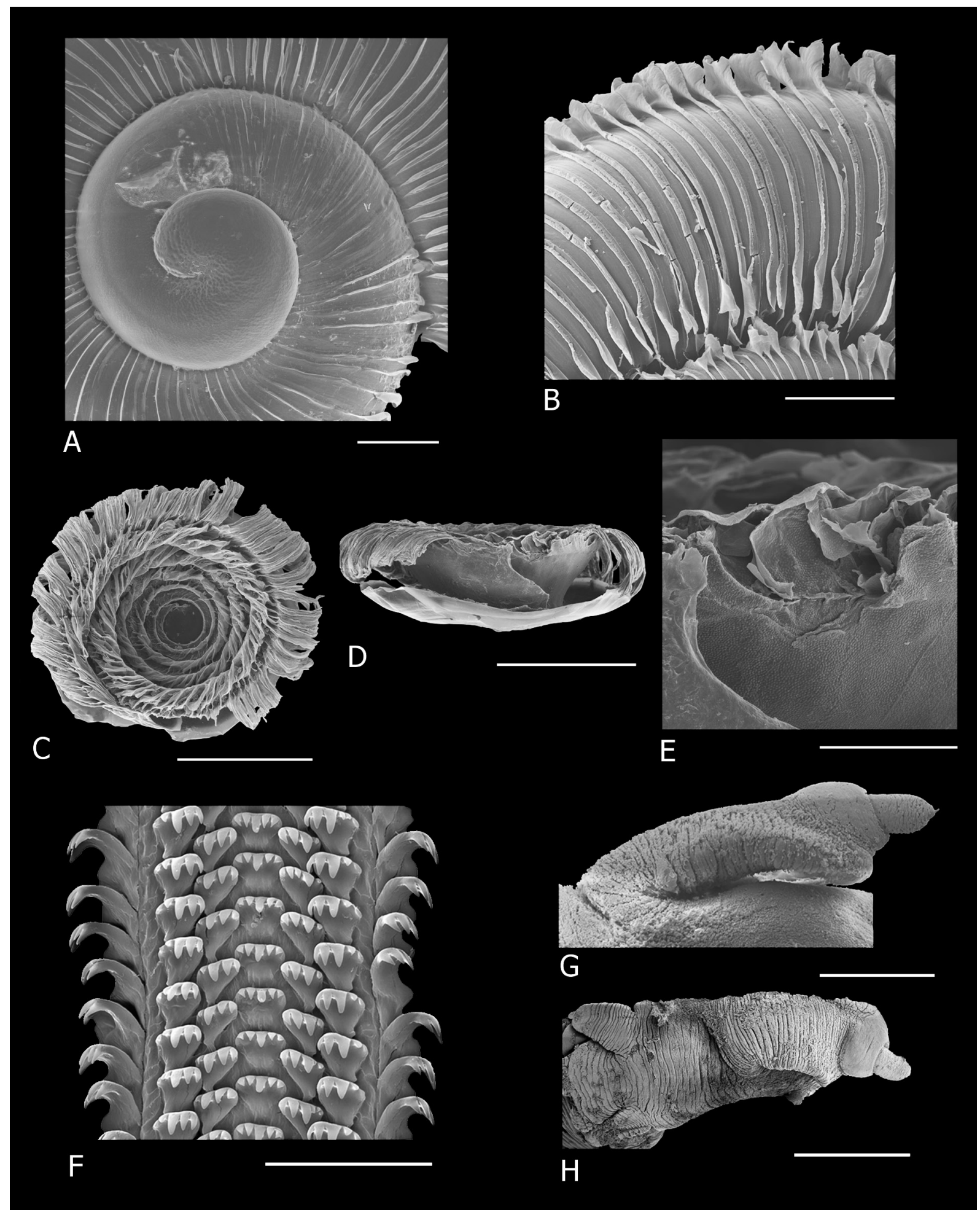

Fig. 21. Chondrocyclus bathrolophodes Connolly, 1929. A. Protoconch (ELM D15882). B. Detail of axial lamellae of periostracum (ELM W3616). C-D. Operculum (ELM W3616). E. Detail of sculpture of wall of operculum (ELM W3616). F. Portion of radula (ELM W3616). G. Penis, lateral view (ELM W3658). H. Penis, dorsal view (ELM W3616). Scale bars: A, E $=200 \mu \mathrm{m} ; \mathrm{B}, \mathrm{G}-\mathrm{H}=500 \mu \mathrm{m}$; C-D = $1 \mathrm{~mm} ; \mathrm{F}=50 \mu \mathrm{m}$. 
specimens sequenced are C. bathrolophodes (Fig. 1). The species was previously thought to occur only in the Port Elizabeth-Albany area, but is shown to have a disjunct distribution. In very close proximity to Kobonqaba to the east, in the Nxaxo forest, Chondrocyclus specimens are morphologically very similar to C. bathrolophodes and C. putealis, but are neither of these species on molecular grounds (Cole et al. 2019; Fig. 1). Chondrocyclus bathrolophodes exhibits very little genetic diversity at the end of a relatively long branch, suggesting recent geographical expansion and severe pruning of ancestral diversity by extinctions. All the coastal taxa of the Eastern clade show complex distribution patterns of sympatry, disjunctions and turnover within sharp contact zones. These could be the result of dynamic changes in vegetation over time, with forest contraction and expansion due to climatic oscillations (Partridge 1993; Partridge et al. 1999). These processes could have caused repeated periods of isolation of populations in shrinking refuges, followed by dispersal and contact.

Chondrocyclus putealis Connolly, 1939

Figs 16B, 22-23

Chondrocyclus putealis Connolly, 1939: 538, pl. xvi, figs 25-27 (type loc.: Southport [Puzey]).

Chondrocyclus putealis - Herbert \& Kilburn 2004: 91.

\section{Diagnosis}

Shell small, depressed, lenticular; periostracum with dense axial costae expanded into three spiral rows of flanges on last whorl. at periphery around umbilicus and below suture; operculum duplex, multispiral lamella of exterior portion deeply concave, with horizontal shelf of interwoven bristles spiralling up on inside of lamella and connected to a very long, loose fringe reflexed over peristome; radula with three large cusps on second lateral tooth; penis flattened dorsoventrally with lateral expansions of shaft towards distal end, more prominent on left side.

\section{Etymology}

The specific name is derived from the Latin 'putealis', meaning 'of or relating to a well', with reference to the deep well-like operculum.

\section{Type material examined}

\section{Syntypes}

SOUTH AFRICA - KwaZulu-Natal • 4 specimens; Natal, Southport; NHMUK 1937.12.30.50871937.12.30.5090. (Fig. 22A)

\section{Other material examined}

SOUTH AFRICA - KwaZulu-Natal 12 specimens; Port Shepstone area, Marble Delta; $30.6509^{\circ} \mathrm{S}$, 30.3560 E; 10 May 2001; D. Herbert leg.; NMSA V9390. - Eastern Cape • 46 specimens; Mkambati Nature Reserve, Mtentu River gorge, south bank, $4.25 \mathrm{~km}$ usptream of mouth; $31.2316^{\circ} \mathrm{S}, 30.0100^{\circ} \mathrm{E}$; 31 m a.s.1.; 12 Jan. 2012; M. Cole leg.; ELM D16954 17 specimens; same collection data as for preceding; ELM W03656 3 specimens in ethanol; same collection data as for preceding; NHMUK 20120272 • 3 specimens in ethanol; same collection data as for preceding; NMW.Z.2012.065.00004 3 specimens in ethanol; same collection data as for preceding; RMNH.MOL 330498 - 3 specimens; Mtentu, north bank, $3.25 \mathrm{~km}$ upstream of mouth, scarp forest on steep slope with large rocks; $31.231000^{\circ} \mathrm{S}, 30.0174^{\circ} \mathrm{E}$; 12 Jan. 2012; M. Cole leg.; ELM D16955 - 5 specimens; same collection data as for preceding; ELM W03657. 


\section{Description}

SHELl (Fig. 22A-D). Small, depressed, lenticular, adult diameter 4.91-5.38 mm, height 2.49-3.26 mm, diameter:height 1.61-2.00 $(\mathrm{n}=20)$. Spire not much raised, apex almost flat (Fig. 22A, C). Embryonic shell (Fig. 23A) approx. 1.75 whorls, microscopically malleate, roughest in centre, junction between embryonic shell and teleoconch evident with appearance of a few weak axial costae, but not sharply demarcated. Teleoconch comprising 2.5-2.75 whorls, moderately convex, rapidly increasing, suture deeply impressed. Aperture circular, last whorl descending strongly near aperture, peristome simple, continuous and free. Umbilicus wid and deep, exposing all the whorls (Fig. 22D). Periostracum glossy, honey-brown and lacquer-like with dense lamellate costae at regular intervals, 107-150 ( $\mathrm{n}=15)$ on last whorl, expanded into paddle-shaped flanges at periphery and umbilicus, as well as a row of shorter broadly rounded lamellae below suture (Fig. 22B-D); flanges bear axial riblets visible at very high magnification (Fig. 23B); intervals between costae with microscopic axial threads.

Operculum (Fig. 23D-E, G-H). Duplex, outer multispiral portion with approx. five whorls; lamellar blade high and steep sided, resulting in a deeply concave outer portion with more-or-less perpendicular sides towards the top and curving inwards towards the bottom; upper edge of lamellar blade thickened, forming a horizontal shelf of interwoven bristles which forms a spiral staircase on the inside of the lamellar blade; in the outermost whorl the latter is connected to a very long fringe reflexed over peristome and preventing operculum being withdrawn into shell. In earlier whorls this fringe is not visible and appears

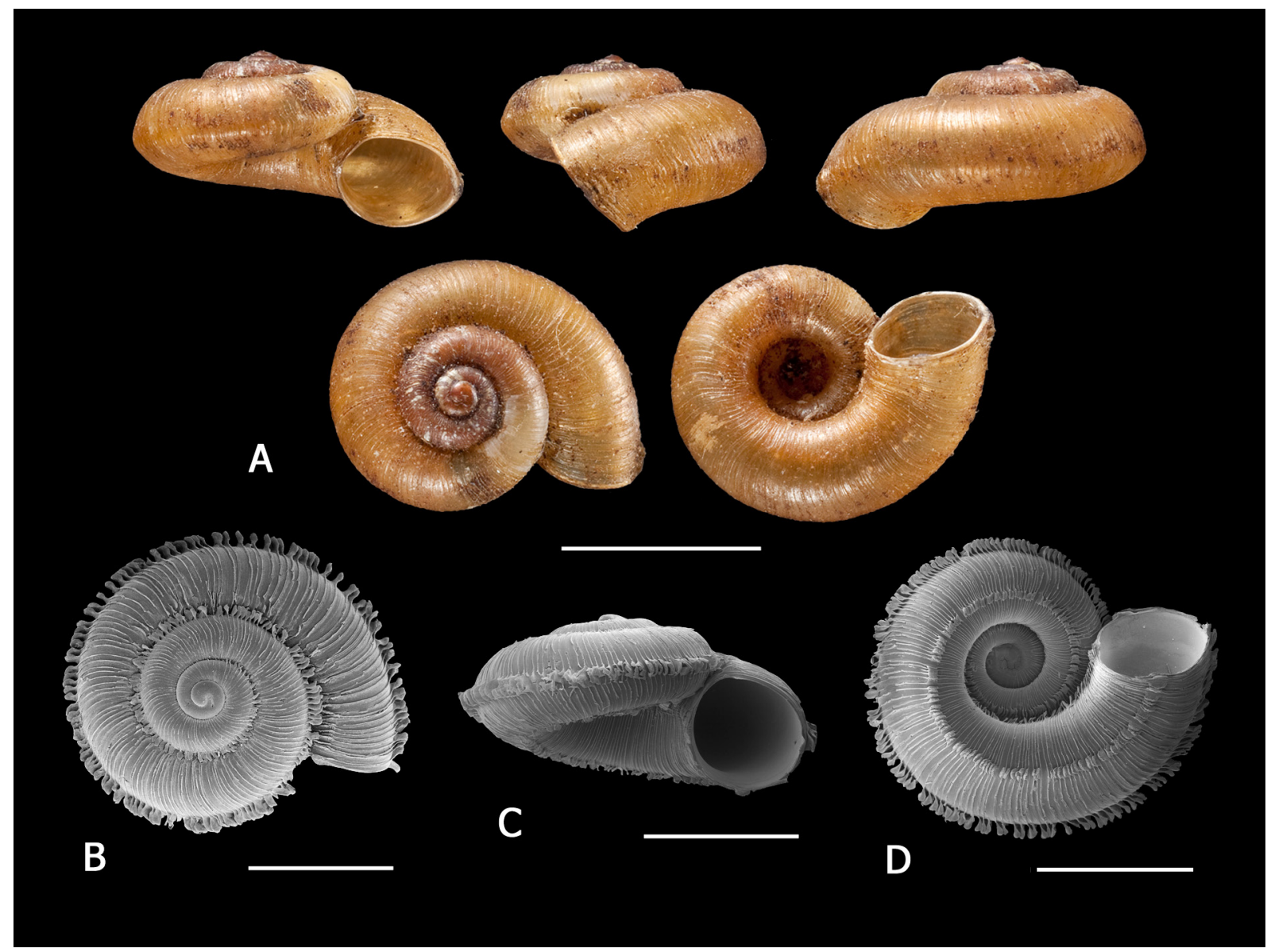

Fig. 22. Chondrocyclus putealis Connolly, 1939. A. Syntypes (NHMUK 1937.12.30.50871937.12.30.5090). B-D. ELM W3656. B. Aperture view. C. Dorsal view. D. Ventral view. Scale bars: $\mathrm{A}=3 \mathrm{~mm}$; $\mathrm{B}-\mathrm{D}=2 \mathrm{~mm}$. 
fused with the lamella; surface of lamella of last whorl tuberculate at high magnification (Fig. 23H). Shell translucent, glossy, honey-brown when fresh.

RadUla (Fig. 23C). Rachidian with five cusps, central one approx. twice length of outer two on each side, the latter four approx. equivalent length; first and second lateral teeth each with three large cusps, a smaller fourth and a vestigial fifth, second lateral tooth is larger.

Penis (Fig. 23F, I). Shaft dorsoventrally flattened, with lateral expansions towards the distal end on both sides but more prominent on left, with numerous annular rugae, distal end bulbous and smooth.

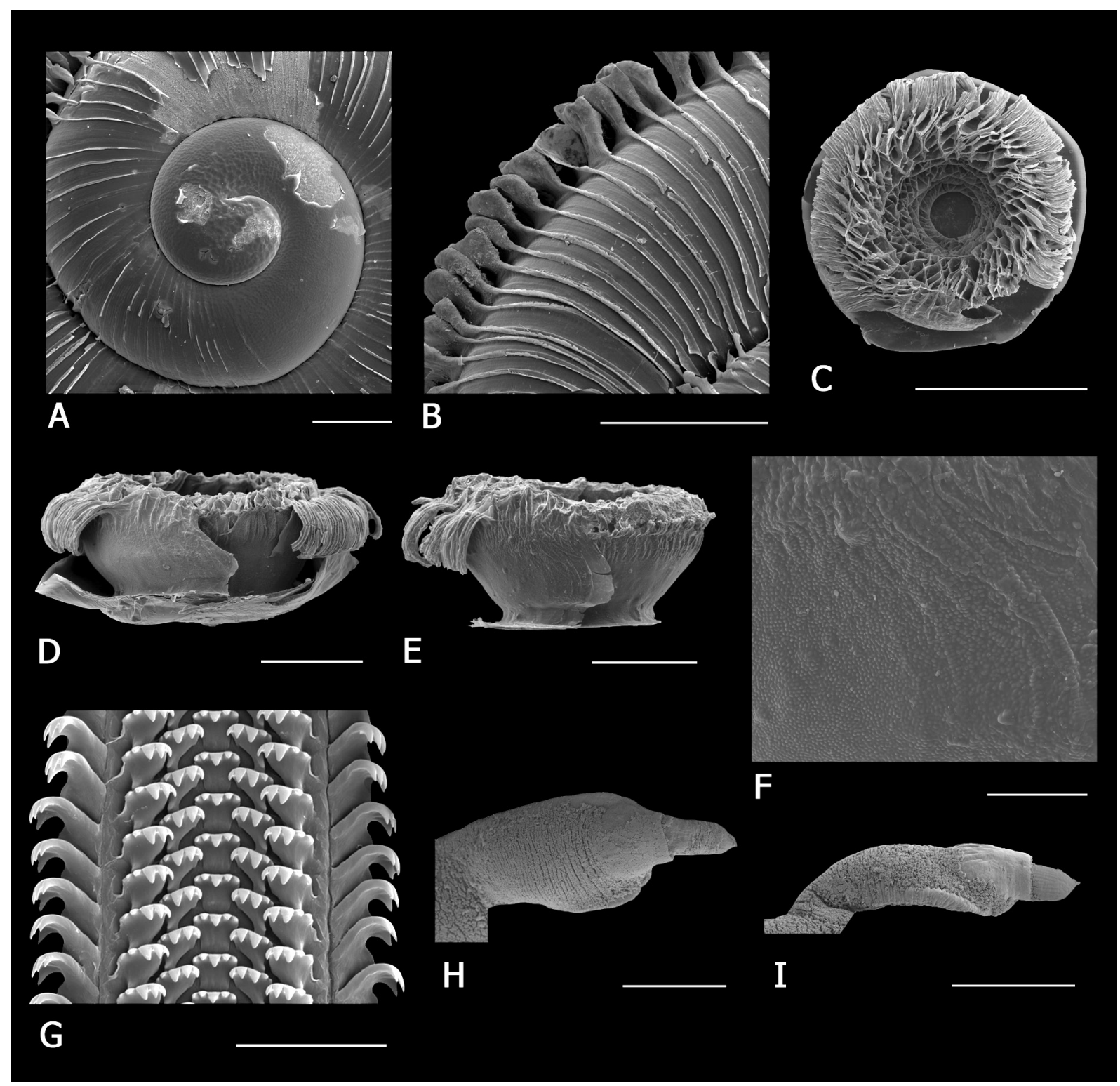

Fig. 23. Chondrocyclus putealis Connolly, 1939. A. Protoconch (ELM W3656). B. Detail of axial lamellae of periostracum (ELM W3656). C. Operculum (ELM W3656). D. Operculum, with disc trimmed (ELM W3656). E. Operculum with some fringe missing (NMSA V9390). F. Detail of sculpture of operculum wall (NMSA V9390). G. Portion of radula (ELM W3656). H. Penis, dorsal view (ELM W3657). I. Penis, lateral view (ELMW3657). Scale bars: A-B $=200 \mu \mathrm{m} ; \mathrm{C}=1 \mathrm{~mm}$; D-E, H-I = $500 \mu \mathrm{m} ; \mathrm{F}=100 \mu \mathrm{m} ; \mathrm{G}=50 \mu \mathrm{m}$. 
COLE M.L., Revision of cyclophorid snails Chondrocyclus s.l.

\section{Distribution and habitat}

Endemic to a narrow range primarily near the coast in southern KwaZulu-Natal and Pondoland (the northeastern region of the Eastern Cape province), between Mtentu in northern Transkei and Southport in southern Kwazulu-Natal, but also recorded inland in the Port Shepstone area (ca $200 \mathrm{~m}$ a.s.1.) (Fig. 16B).

Indigenous Scarp Forest (Mucina \& Geldenhuys 2006) on banks of rivers, in leaf litter.

\section{Remarks}

Morphological differences between C. putealis and C. bathrolophodes are slight. The shell of C. putealis resembles C. bathrolophodes in shape but attains slightly smaller size. The position of spiral rows of flanges is similar in the two species, but costae are slightly more dense on average in $C$. putealis and the peripheral and umbilical cords stronger than those of $C$. bathrolophodes. The opercula of the two species are very similar although the operculum of $C$. putealis is deeper with perpendicular sides near the top and curving inward near the disc, while the lamellar blade of $C$. bathrolophodes widens evenly towards the top. Both species occupy a relatively narrow range, separated geographically by a wide intervening distance in which $C$. cooperae sp. nov. (below) and $C$. pondoensis sp. nov. occur. On morphological grounds alone, it was not clear whether C. putealis and C. bathrolophodes should indeed be considered distinct species, in spite of subtle differences. In the molecular analyses $C$. pondoensis sp. nov. is nested within this group (Fig. 1), adding weight to the evidence to treat these lineages as distinct species.

Chondrocyclus putealis appears to be a very rare species and there are only a few localities where recent specimens could be found and it was patchily distributed at these localities. Chondrocyclus putealis is replaced by the closely related $C$. cooperae sp. nov. westwards along the coast, while $C$. pondoensis sp. nov. also extends westwards from Pondoland and is sympatric with both these species. This region of the north-eastern coast of the Eastern Cape is an important centre of cladogenic events in rhytidid molluscs (Moussalli et al. 2009; Herbert \& Moussalli 2010) and is a focus of endemism in sylvian mollusc taxa (Bursey \& Herbert 2004; Herbert \& Kilburn 2004; Cole \& Herbert 2009; Herbert 2017). Botanically, this area harbours a large number of palaeoendemics and neoendemics concentrated in scarp forests in deep gorges (van Wyk \& Smith 2001; Mucina et al. 2007).

Chondrocyclus cooperae sp. nov. urn:1sid:zoobank.org:act:16788B3B-03BE-4452-B52C-83D7FE070A53

Figs 10M-N, 16B, 24

Chondrocyclus putealis - Herbert \& Kilburn 2004: 91.

\section{Diagnosis}

Shell small, depressed, lenticular; periostracum with dense axial costae expanded into seven spiral rows of flanges on last whorl: one at periphery, and three each between periphery and suture and between periphery and umbilicus; costae and flanges bear numerous tiny vertical ridges; operculum duplex, exterior concave portion shaped like a wide cup or bowl, multispiral lamella with horizontal shelf of interwoven bristles spiralling up on inside of bowl, fused to a very long, loose fringe reflexed over peristome; radula with three large cusps on second lateral tooth; penis flattened dorsoventrally with prominent lateral expansion on left of shaft towards distal end, and with a characteristic long intromittent organ.

\section{Etymology}

Named for Janna Cooper, who helped collect specimens of this species and in recognition of her intimate knowledge of the Transkei coast. 


\section{Type material examined}

\section{Holotype}

SOUTH AFRICA - Eastern Cape - Umtiza Nature Reserve, east side of Buffalo Pass, indigenous scarp forest; $33.0144^{\circ}$ S: $27.8081^{\circ}$ E; 21 Apr. 2006; M. Bursey leg.; in leaf litter; NMSA W9271/T3074. (Fig. 10M-N)

\section{Paratypes}

SOUTH AFRICA - Eastern Cape • 2 specimens; same collection data as for holotype; ELM D14918/ T122 15 specimens; same collection data as for preceding; M. Cole leg., 18 Mar. 2011; ELM D16936/ T120 5 specimens; same collection data as for preceding; ELM W3623/T121 • 4 specimens; same collection data as for preceding; NHMUK 20120280 • 2 specimens; same collection data as for preceding; NMSA W9275/T3076 • 1 specimen; same collection data as for preceding; NMW.Z.2012.065.00009 • 3 specimens; same collection data as for preceding; RMNH MOL.330502 3 specimens; same collection data as for preceding; 20 May 2011; M. Cole leg.; ELM D17008/T123 • 4 specimens; Hickmans River, dune forest west of lagoon; $33.0700^{\circ} \mathrm{S}, 27.8364^{\circ} \mathrm{E}$; 15 Mar. 2003; M. Bursey; ELM D16934/ T124 15 specimens; East London, Nahoon estuary east bank, $1 \mathrm{~km}$ upstream of mouth; $32.9804^{\circ} \mathrm{S}$, 27.9433 E; 2 Jun. 2003; M. Bursey leg.; ELM D15533/T126 • 1 specimen; same collection data as for preceding; ELM W3681/T125 - 3 specimens; same collection data as for preceding; 8 Dec. 2009; M. Cole leg., ELM D16931/T127 • 11 specimens; same collection data as for preceding; ELM W03621/ T128 7 specimens; same collection data as for preceding; 30 Mar. 2011; M. Cole and D.-J. Hodgkinson leg., ELM W03622/T129 • 5 specimens; Gqunube Green, east bank of Gonubie River, 1 km upstream of mouth, forest on steep slope; $32.9329^{\circ} \mathrm{S}, 28.0235^{\circ} \mathrm{E}$; 9 Apr. 2003; M. Bursey leg.; ELM W03028/ T130 - 5 specimens; Gqunube Green, Wilderness Valley, tributary of Gonubie River on east bank $2.5 \mathrm{~km}$ upstream of mouth; $32.9303^{\circ} \mathrm{S}, 28.0128^{\circ} \mathrm{E}$; $11 \mathrm{Apr}$. 2002; M. Cole leg., ELM D17009/T131 •

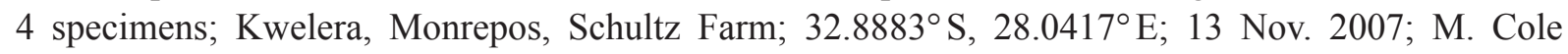
leg., ELM D15603/T132 • 11 specimens; Viskop, east bank of Cefane River; $32.8047^{\circ} \mathrm{S}, 28.1319^{\circ} \mathrm{E}$; 20 Nov. 2006; M. Bursey leg.; ELM D15121/T133 • 5 specimens; same collection data as for preceding; ELM W03112/T134 - 12 specimens; same collection data as for preceding; 30 Dec. 2009; M. Cole leg., ELM D16929/T135 • 1 specimen; same collection data as for preceding; ELM W03620/T136 • 3 specimens; Mazeppa Bay, east bank of Sihlontlweni estuary near mouth; $32.4783^{\circ} \mathrm{S} ; 28.6460^{\circ} \mathrm{E}$; 28 m a.s.1.; 23 Apr. 2015; M. Cole leg., ELM D17931/T137 • 3 specimens; same collection data as for preceding; ELM W03867/T138 1 specimen; Colleywobbles, south facing slope above vulture colony, sparse thicket invaded with Lantana; $31.9833^{\circ} \mathrm{S}, 28.5833^{\circ} \mathrm{E} ; 20 \mathrm{Feb}$. 2006; M. Bursey leg.; ELM D14968/T139 - 1 specimen; Dwesa Nature Reserve, forest along roadside east of camp; $32.1528^{\circ} \mathrm{S}$, 28.8417 E; 7 Mar. 2000; M. Bursey leg.; ELM W03212/T140; 5 specimens; same collection data as for preceding; 20 Feb. 2011; R. Daniels leg.; ELM D16935/T141 • 3 specimens; Xora, Nxeni Forest, east bank of Ntlonyane River; $32.1933^{\circ}$ S, $28.9574^{\circ}$ E; 8 Nov. 2012; M. and K. Cole leg., ELM D17499/ T142 13 specimens; same collection data as for preceding; ELM W03813/T143 • 2 specimens; Mpame forest; $32.0856^{\circ} \mathrm{S}, 29.0306^{\circ} \mathrm{E}$; 20 Feb. 2009; M. Cole leg.; ELM D16937/T144 • 2 specimens; same collection data as for preceding; ELM W03624/T145 • 2 specimens; Hluleka Nature Reserve, forest on north bank of river, steeply sloping, after second bridge along forest road; $31.8196^{\circ} \mathrm{S}, 29.3155^{\circ} \mathrm{E}$; 20 Apr. 2005; M. Bursey leg.; ELM D15529/T146 • 4 specimens; Port St. Johns, east bank of Umzimvubu River, $3 \mathrm{~km}$ upstream; $31.5972^{\circ} \mathrm{S}, 29.5350^{\circ} \mathrm{E} ; 6$ Jul. 2006; M. Bursey and V. Ndibo leg.; alive in leaflitter; ELM D15227/T147 - 3 specimens; Port St. Johns, travertine deposit area, $26 \mathrm{~km}$ upstream on Umzimvubu River; $31.5211^{\circ} \mathrm{S}, 29.4569^{\circ} \mathrm{E}$; 22 Apr. 2005; M. Bursey and V. Ndibo leg.; ELM D15311/ T148 7 specimens; Mbotyi, forest near Mkozi River, south-facing forest on steep slope on east bank of Mkozi River; $31.4459^{\circ}$ S, $29.7549^{\circ}$ E; 2 Mar. 2003; M. Bursey leg.; ELM D14394/T149 • 1 specimen; same collection data as for preceding; ELM W2836/T150. 
COLE M.L., Revision of cyclophorid snails Chondrocyclus s.l.

\section{Other material examined}

SOUTH AFRICA - Eastern Cape - 1 specimen; Umtiza Nature Reserve, east side of Buffalo Pass, indigenous scarp forest; $33.0144^{\circ} \mathrm{S}, 27.8081^{\circ} \mathrm{E}$; Nov. 1993; C.J. Vernon leg.; ELM D13141 • 32 spcimens; East London, Nahoon estuary east bank, $1 \mathrm{~km}$ upstream of mouth; $32.9804^{\circ} \mathrm{S}, 27.9433^{\circ} \mathrm{E}$; 30 Mar. 2011; M. Cole and D.-J. Hodgkinson leg.; ELM D16932 • 1 specimen; East London, forest below casino, west bank of Nahoon River near Abbotsford causeway, $4.5 \mathrm{~km}$ upstream of mouth; $32.9692^{\circ} \mathrm{S}, 27.906000^{\circ} \mathrm{E} ; 28$ Jan. 2008; M. Cole leg.; ELM D16959 • 4 specimens; Gqunube Green, east bank of Gonubie River, $1 \mathrm{~km}$ upstream of mouth, forest on steep slope; $32.9329^{\circ} \mathrm{S}, 28.0235^{\circ} \mathrm{E} ; 9$ Apr. 2003; M. Bursey leg.; ELM D13644 • 1 specimen; Inkwenkwezi Private Game Reserve, inland of Cintsa; $32.8333^{\circ} \mathrm{S}, 28.0667^{\circ} \mathrm{E} ; 22$ Nov. 2006; M. Bursey leg.; ELM D15186 • 4 specimens; Viskop, east bank of Cefane River; $32.8047^{\circ} \mathrm{S}, 28.1319^{\circ} \mathrm{E} ; 8$ Apr. 2000; M. Bursey leg.; ELM D16930 • 2 specimens; same collection data as for preceding; 15 Jun. 2000; ELM D15536 3 specimens; Morgan's Bay, Yellowood Park, $2 \mathrm{~km}$ upstream of mouth, riverine forest on south-west facing slope, predominantly Strelitzia nicolai; $32.6967^{\circ} \mathrm{S}, 28.3347^{\circ} \mathrm{E}$; 14 Mar. 2005; M. Bursey leg.; ELM D15338 • 5 specimens; same collection data as for preceding; 6 Mar. 2011; R. Daniels leg.; ELM D16968 • 1 specimen; Dwesa Nature Reserve, forest along roadside east of camp; $32.1528^{\circ} \mathrm{S}, 28.8417^{\circ} \mathrm{E}$; 5 Mar. 2000; M. Bursey leg.; ELM W03261 - 28 specimens; Xora, Nxeni Forest, east bank of Ntlonyane River; $32.1933^{\circ} \mathrm{S}$, $28.9574^{\circ}$ E; 11 Aug. 2011; M. Cole leg.; ELM D16938 • 7 specimens; same collection data as for preceding; ELM W03625 - 2 specimens; Sinangwana, Sigxeni Forest, east bank of Sinangwana River; $31.7474^{\circ} \mathrm{S}, 29.3708^{\circ}$ E; 21 Apr. 2005; M. Bursey leg.; ELM D15427 • 3 specimens; Port St. Johns, east side of Umzimvubu River in valley north of Mount Sullivan; $31.5899^{\circ} \mathrm{S}, 29.5451^{\circ} \mathrm{E}$; M. Bursey and V. Ndibo leg.; 6 Jul. 2006; alive in leaf-litter; ELM D15235.

\section{Description}

SHELl (Fig. 24A-C). Small, depressed, lenticular, adult diameter 4.51-6.51 mm, height 2.25-4.01 mm, diameter:height 1.44-2.32 ( $\mathrm{n}=66$, measured in several populations throughout the range). Spire not much raised, apex almost flat (Fig. 24A). Embryonic shell (Fig. 23D) just under 1.75 whorls, microscopically malleate, roughest in centre, junction between embryonic shell and teleoconch evident with appearance of a few weak costae, but not sharply demarcated. Teleoconch comprising 2.75 whorls, moderately convex, rapidly increasing, suture deeply impressed. Aperture circular, last whorl descending strongly near aperture, peristome simple, continuous and free. Umbilicus wide and deep, exposing all the whorls (Fig. 24C). Periostracum glossy, honey-brown and lacquer-like with dense lamellate axial costae at regular intervals, density varying between populations, $105-179$ ( $n=27$, counted in three separate populations), expanded into tall quadrangularly-shaped flanges at periphery, and six additional spiral rows of lowerstanding flanges on body whorl, three between suture and periphery and three rows between periphery and umbilicus, the row closest to umbilicus weaker than other rows (Fig. 24A-C); flanges and portion of costae near umbilicus bear axial ridges visible at very high magnification (Fig. 24E); intervals between costae with microscopic axial threads. Shell translucent, glossy, honey-brown when fresh.

Living ANIMAL. Head, tentacles and snout dark grey, underside of foot creamy white.

OperCulum (Fig. 24G-H). Duplex, outer multispiral portion with 5.5 whorls forming a widely cupolaeform cup or bowl, upper edge of lamellar blade thickened, forming a horizontal shelf of interwoven bristles in a lattice-like pattern; in the outermost whorl the latter is continuous with a very long fringe reflexed over peristome and preventing operculum being withdrawn into shell; in earlier whorls this fringe is not visible and appears fused with the lamella; growing edge of lamella arrow shaped. Surface of lamella of last whorl tuberculate at high magnification. 
RadUla (Fig. 24F). Rachidian with five cusps, central one approx. twice length of outer two on each side; first and second lateral teeth similar but second is larger, each with four cusps and a vestigial fifth; first three cusps gradually increasing in size from centre outwards and fourth very small.

PenIs (Fig. 24I-J). Shaft dorsoventrally flattened, with large lateral expansion on left side, with numerous annular rugae, distal end smooth and not bulbous, intromittent organ very long.

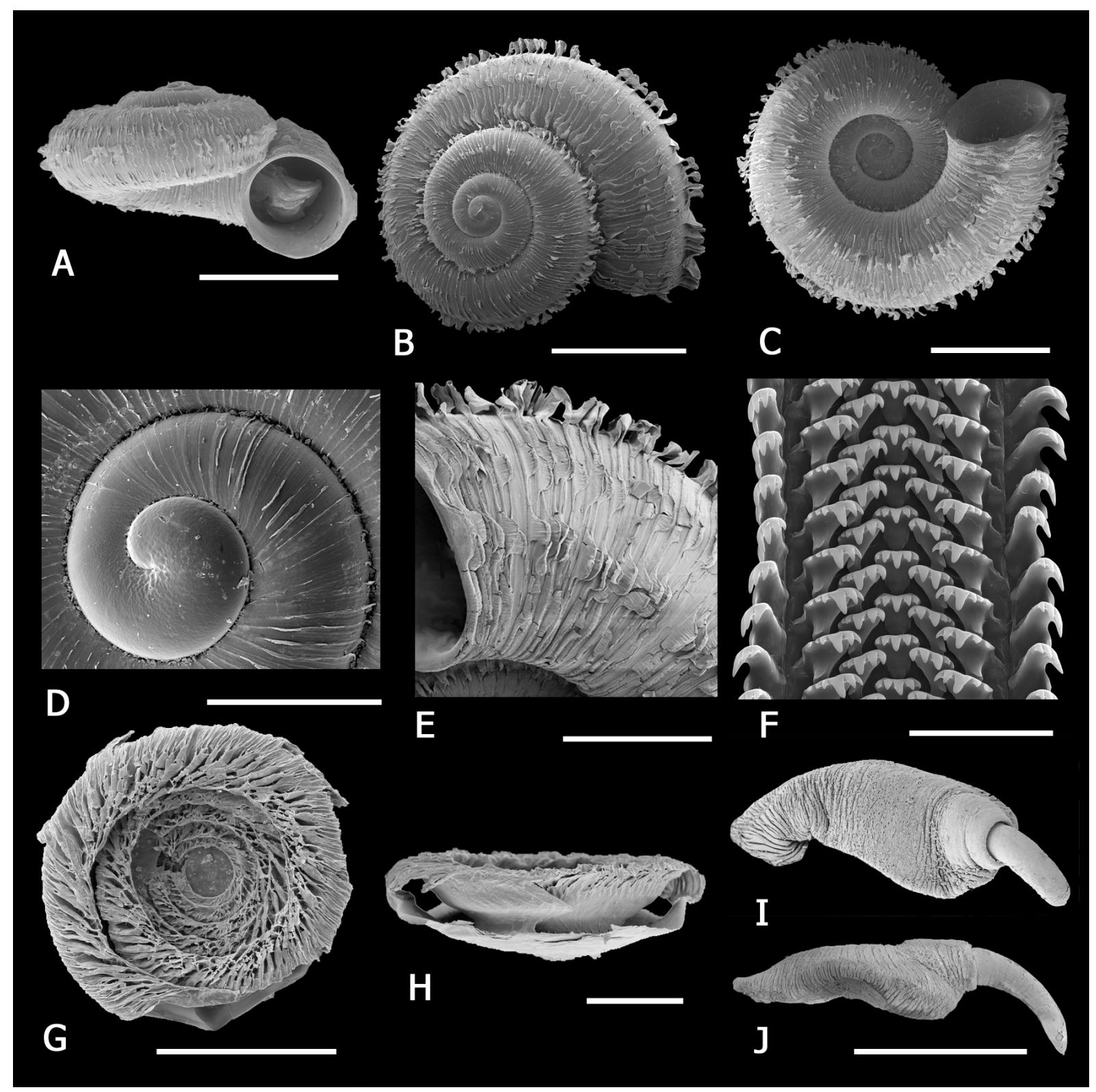

Fig. 24. Chondrocyclus cooperae sp. nov. A. Aperture view (ELM W3620/T136). B. Dorsal view (ELM W3620/T136). C. Ventral view (ELM W3620/T136). D. Protoconch (ELM W3620/T136). E. Detail of axial lamellae of periostracum (ELM W3620/T136). F. Portion of radula (ELM W3623/T121). G-H. Operculum (ELM W3623/T121). I. Penis, dorsal view (ELM W3623/T121). J. Penis, lateral view (ELM W3212/T140). Scale bars: A-C = 2 mm; D, H $=500 \mu \mathrm{m} ; \mathrm{E}, \mathrm{G}, \mathrm{I}-\mathrm{J}=1 \mathrm{~mm} ; \mathrm{F}=50 \mu \mathrm{m}$. 
COLE M.L., Revision of cyclophorid snails Chondrocyclus s.l.

\section{Distribution and habitat}

Endemic to Eastern Cape from East London to Mbotyi, primarily near the coast. The range of C. cooperae sp. nov. overlaps with that of $C$. bathrolophodes in the west, and C. pondoensis sp. nov. in the east (Fig. 16B).

Indigenous Scarp Forest (Mucina \& Geldenhuys 2006) and Eastern Cape Dune Forest (von Maltitz et al. 2003), in leaf litter.

\section{Remarks}

Chondrocyclus cooperae sp. nov. resembles C. bathrolophodes and C. putealis in general shape, operculum and radula, but differs consistently in the larger number of spiral rows of periostracal flanges. The very long intromittent organ of the penis is unmistakable and immediately distinguishes the species.

Chondrocyclus langebergensis sp. nov.

urn:lsid:zoobank.org:act:9C3B5371-50CA-43DD-A684-1796648C24BA

Figs 5, 10O, R, 25

Chondrocyclus convexiusculus - Connolly 1939: 537. — Herbert \& Kilburn 2004: 91.

\section{Diagnosis}

Shell small, very depressed, discoidal; periostracum with axial costae producing spiral rows of simple, robust hairs concentrated at and on either side of periphery; operculum duplex, exterior portion very shallowly concave, with thickened ridge on multispiral lamella from which emanates a fairly long solid fringe and a very short fringe below this; radula with three large cusps on second lateral tooth.

\section{Etymology}

Named after the Langeberg mountain range, part of the Cape Fold Mountains.

\section{Type material examined}

\section{Holotype}

SOUTH AFRICA - Western Cape - Langeberge foothills, Pat Busch Nature Reserve, Karin Trail, riverine fynbos; $33.7551^{\circ} \mathrm{S}, 19.9947^{\circ} \mathrm{E} ; 450 \mathrm{~m}$ a.s.1.; 7 Aug. 2014; M. Cole leg.; in leaf-litter beneath bushes; NMSA P0642/T4159. (Fig. 10O, R)

\section{Paratypes}

SOUTH AFRICA - Western Cape • 21 specimens; same collection data as for holotype; ELM D17981/ T98 1 specimen; same collection data as for holotype; ELM W3899/T99 14 specimens; same collection data as for holotype; 10 Oct. 2007; D. Herbert and L. Davis leg.; NMSA W5768/T4120 117 specimens; same collection data as for holotype; 3 Mar. 2012; R. Daniels leg.; ELM D16920/T97 • 40 specimens; Langeberg Mountains, Heidelberg area, Grootvadersbosch Nat. Res., Bushbuck Trail, Afrotemperate forest; 33.9819 ${ }^{\circ} \mathrm{S}, 20.8321^{\circ} \mathrm{E}$; 19 Apr. 2012; M. Cole leg.; in leaf litter; ELM D16999/T90 • 6 specimens; same collection data as for preceding; ELM W3660/T91 1 specimen; same collection data as for preceding; NHMUK 20120284 • 113 specimens; same collection data as for preceding; 3 Mar. 2012; R. Daniels leg.; ELM D16918/T100 • 7 specimens; same collection data as for preceding; ELM W03613/ T92 - 5 specimens; same collection data as for preceding; NHMUK 20120283 • 5 specimens; same collection data as for preceding; NMW.Z.2012.065.00011 - 5 specimens; same collection data as for preceding; RMNH MOL.330500 5 specimens; Grootvadersbosch Nat. Res. Melkhoutpad; $33.9819^{\circ} \mathrm{S}$, $20.8321^{\circ}$ E; 16 Sep. 2009; M. Cole leg.; ELM D16917/T93 • 1 specimen; same collection data as for preceding; W3689/T94 • 6 specimens; Grootvadersbosch Nat. Res., Redwoods area, Podocarpus forest; 
33.9826 ${ }^{\circ}$ S, $20.8296^{\circ}$ E; 224 m a.s.1.; 14 Sep. 2003; J. Londt leg.; NMSA W1043/T4117 • 20 specimens; Grootvadersbosch Nat. Res.; 33.9959 $\mathrm{S}, 20.8129^{\circ} \mathrm{E}$; 22 Feb. 2005; A. Moussalli and D. Stuart-Fox leg.; NMSA W5008/T4119 • 176 specimens; Marloth Nature Reserve, Swellendam, Duivelsbos Forest, 33.9934 ${ }^{\circ}$ S, $20.4587^{\circ}$ E; 15 Sep. 2009; M. Cole leg.; ELM D16919/T95 • 31 specimens; same collection data as for preceding; W03614/T96 4 specimens; Marloth Nat. Res., afrotemperate forest; $33.9897^{\circ} \mathrm{S}$, 20.4544 E; 23 Feb. 2005; A. Moussalli and D. Stuart-Fox leg.; in leaf-litter; NMSA W5016/T4118 • 6 specimens; Montagu; $33.7833^{\circ}$ S, $20.1167^{\circ}$ E; M. Connolly leg.; NMSA 2778/T4116.

\section{Description}

Shell (Fig. 25A-C). Small, very depressed, discoidal, adult diameter 3.63-5.76 mm, height $1.42-$ $2.76 \mathrm{~mm}$, diameter:height $1.79-2.85(\mathrm{n}=67$, measured in four different populations; Table 3$)$. Spire almost flat (Fig. 25A), sometimes concave, usually with only the mammillate, tilted protoconch projecting. Embryonic shell (Fig. 25D) approx. 2-2.25 whorls, microscopically malleate, junction between embryonic shell and teleoconch evident with development of widely spaced axial costae on teleoconch. Teleoconch comprising 2.25 whorls, very rapidly increasing, convex, suture deeply impressed. Aperture circular, last whorl descending steeply nearing aperture, peristome simple, continuous and free. Umbilicus very wide, exposing all the whorls (Fig. 25C). Periostracum glossy and lacquer-like with lamellate axial costae at regular intervals, $47-63(\mathrm{n}=14)$ on last whorl in Grootvadersbosch population but varies between populations (Table 3 ), which produce six spiral rows of simple, very long and robust hairs around the periphery; intervals between costae with six-eight microscopic axial threads. Shell translucent reddish brown, honey brown or yellowish-white when fresh. Living animal. Variable in colour between populations from creamy white with light brown pigmentation on tentacles to almost black, underside of foot creamy white.

Operculum (Fig. 25F, I). Duplex and shallowly concave; multispiral lamella of outer portion with five low whorls, thickened horizontal ridge near base of lamellar blade runs parallel to disc surface, a long fringe of fused bristles and a second very short fringe below it emanate from this ridge; main fringe grows upwards (i.e., parallel to lamellar blade) and then downwards, leaving a deep, wide groove between fringe and blade of lamella; lamellar blade projects above level of fringe and is very thin; fringe of each whorl fused to lamellar blade of next whorl; fringe of outermost whorl overlaps disc slightly and is reflexed over peristome in life although operculum is retractile.

Radula (Fig. 25E). Rachidian with five cusps, middle one longer than 2 cusps on either side of it; first and second lateral teeth with five cusps ( $5^{\text {th }}$ sometimes vestigial), the third cusp from centre the largest.

PENIS (Fig. 25G-H). Shaft more or less cylindrical and slightly flattened dorsoventrally, distal half slightly expanded on left side, numerous annular rugae, distal end smooth but not bulbous, intromittent organ short.

\section{Distribution and habitat}

Western Cape, evidently endemic to Langeberg mountain range in Cape Fold Mountain belt, southfacing slopes and on northern side of range in Montagu area (Fig. 5).

Diverse vegetation types: patches of Western Cape Afrotemperate Forest (von Maltitz et al. 2003) and riverine fynbos, in leaf litter.

\section{Remarks}

In terms of its hairy periostracum Chondrocyclus langebergensis sp. nov. resembles Afrocyclus isipingoensis gen. et comb. nov., but the molecular analyses placed C. langebergensis sp. nov. and C. kevincolei sp. nov. in a well-supported monophyletic clade, termed the Overberg clade, within the 
COLE M.L., Revision of cyclophorid snails Chondrocyclus s.l.

Table 3. Measurements of Chondrocyclus langebergensis sp. nov., showing variation between populations; $\mathrm{D}=$ shell diameter, $\mathrm{H}=$ height, costae = number of axial ribs on body whorl, $\mathrm{Avg}=$ average.

\begin{tabular}{lccccccccccccc}
\hline Site & D max D min & Avg & H max H min & Avg & D/H max D/H min & Avg & n Costae & Avg & n \\
\hline Patbusch & 5.76 & 4.68 & 5.17 & 2.76 & 2.21 & 2.48 & 2.33 & 1.79 & 2.09 & 23 & $71-99$ & 81 & 14 \\
Montagu & 5.32 & 4.98 & 5.11 & 2.62 & 2.32 & 2.48 & 2.23 & 1.92 & 2.07 & 5 & 74 & 74 & 1 \\
Marloth & 4.24 & 3.63 & 3.92 & 1.95 & 1.51 & 1.79 & 2.57 & 2.00 & 2.20 & 20 & $69-85$ & 79 & 5 \\
Grootvadersbosch & 5.09 & 3.42 & 4.56 & 2.17 & 1.42 & 1.82 & 2.85 & 2.20 & 2.51 & 19 & $47-63$ & 53 & 14 \\
\hline
\end{tabular}

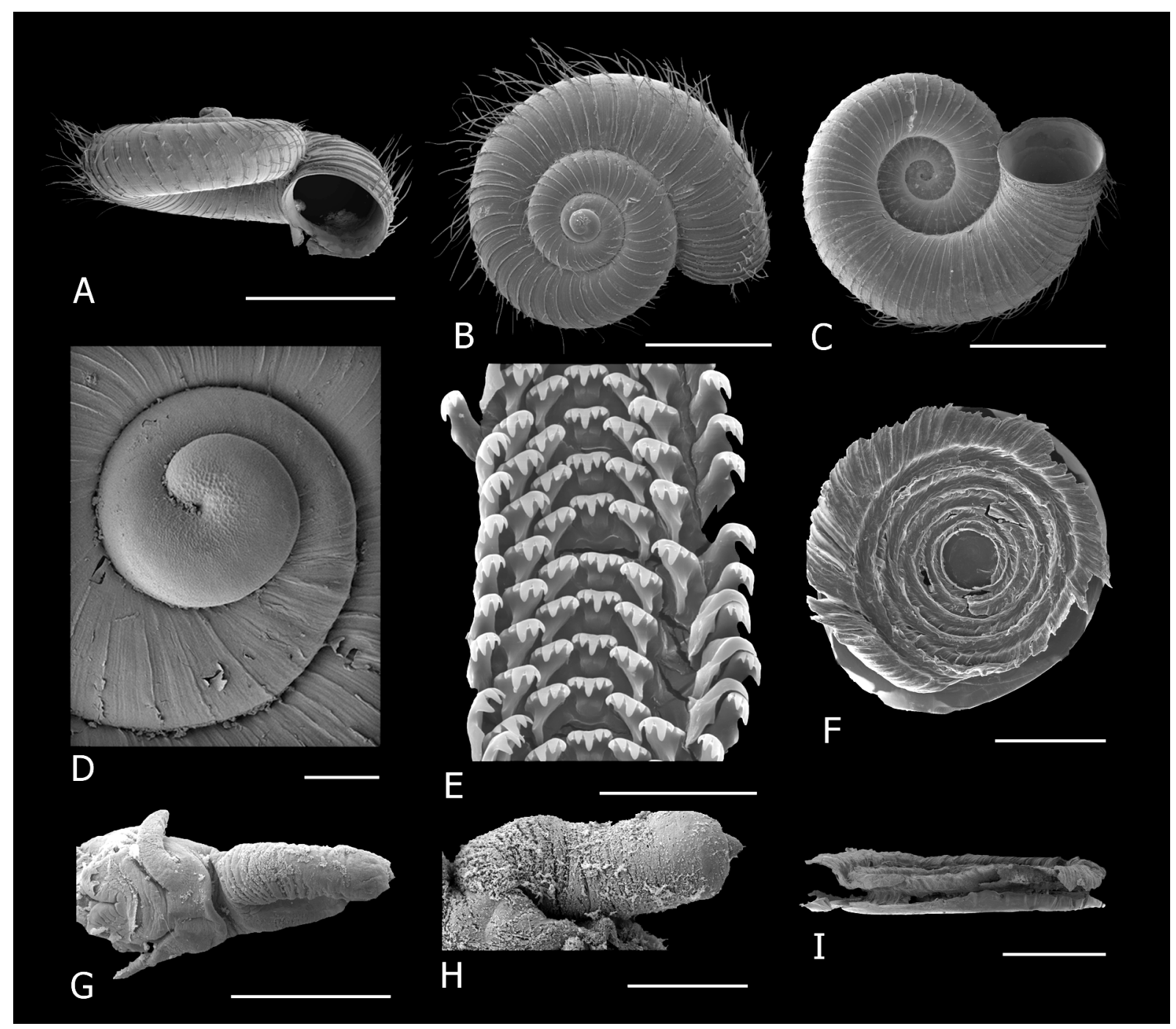

Fig. 25. Chondrocyclus langebergensis sp. nov. A. Aperture view (NMSA W1043/T4117). B. Dorsal view (NMSA W5008/T4119). C. Ventral view (NMSA W5008/T4119). D. Protoconch (ELM W3614/ T96). E. Portion of radula (NMSA W5008/T4119). F. Operculum, dorsal view (ELM W3614/T96). G. Penis, dorsal view showing position behind right tentacle (ELM W3660/T91). H. Penis, lateral view (NMSA W5008/T4119). I. Operculum, lateral view (NMSA W5008/T4119). Scale bars: A-C $=2$ mm; $\mathrm{D}=200 \mu \mathrm{m} ; \mathrm{E}=50 \mu \mathrm{m} ; \mathrm{F}, \mathrm{I}=500 \mu \mathrm{m} ; \mathrm{G}-\mathrm{H}=1 \mathrm{~mm}$. 
Chondrocyclus s.s. radiation (Cole et al. 2019; Fig. 1). The major morphological feature distinguishing this clade from $A$. isipingoensis gen. et comb. nov. is that the second lateral tooth of the radula has three large cusps (Fig. 25E) as opposed to two in A. isipinoensis comb. nov. (Fig. 27E). Differences between $C$. langebergensis sp. nov. and C. kevincolei $\mathrm{sp}$. nov. are discussed under the latter species.

The Overberg clade and the other taxon in the southwestern Cape, C. convexiusculus, have not been recorded sympatrically although they occur in close proximity inland in the upper Breede River valley and near the coast (Fig. 5). Other taxa also contain distinct clades in either the Hottentots-Holland Mountains or the Overberg which do not occur in the other region (e.g., Gouws et al. 2010; Herbert \& Moussalli 2010; McDonald et al. 2012; Daniels et al. 2013) and the Breede River valley is considered an important barrier to gene flow (Weimarck 1941; Linder 2003; McDonald \& Daniels 2012).

Chondrocyclus kevincolei sp. nov. urn:1sid:zoobank.org:act:2C3567A2-1004-4E9B-9452-C6E657323E18

Figs 5, 10P-Q, 26

Chondrocyclus convexiusculus - Connolly 1939: 537.

\section{Diagnosis}

Shell small, depressed, lenticular; periostracum with axial costae producing spiral rows of simple hairs; spiral grooves on shell corresponding with rows of hairs; operculum duplex, exterior portion very shallowly concave, with step-shaped multispiral lamella terminating in a short fringe with uneven edge, diameter of exterior portion less than diameter of inner disc; radula with three large cusps on second lateral tooth.

\section{Etymology}

Named for the author's husband, Kevin Cole, in acknowledgement of his indispensable assistance on fieldtrips.

\section{Type material examined}

\section{Holotype}

SOUTH AFRICA - Western Cape • Platbos Forest near Gansbaai, Western Cape Milkwood Forest with large trees including Sideroxylon inerme Linne and Celtis africana N.L.Burm; $34.5671^{\circ} \mathrm{S}, 19.4495^{\circ} \mathrm{E}$; 13 Aug. 2014; M. and K. Cole leg.; in leaf litter; NMSA W9270/T3073. (Fig. 10P-Q)

\section{Paratypes}

SOUTH AFRICA - Western Cape 1 specimen; same collection data as for holotype; ELM D18004/ T85 - 2 specimens; same collection data as for holotype; ELM W3898/T86 • 327 specimens; same collection data as for preceding; 9 Sep. 2009; M. Cole, K. Cole, D-J Hodgkinson and T. Pretorius leg.; ELM D16921/T81 - 90 specimens; same collection data as for preceding; ELM W3615/T82 • 20 specimens; same collection data as for preceding; NHMUK 20120282 23 specimens; same collection data as for preceding; NMSA P0598/T4121 • 18 specimens; same collection data as for preceding; NMW.Z.2012.065.00010 • 15 specimens; same collection data as for preceding; RMNH MOL.330503 • 47 specimens; same collection data as for preceding; 18 Apr. 2012; M. Cole, D. Herbert and L. Davis leg.; ELM D16998/T83 • 5 specimens; same collection data as for preceding; ELM W3659/T84 27 specimens; Bredasdorp, about 5 miles to SW, on Elim Rd; $34.5450^{\circ} \mathrm{S}, 19.9614^{\circ} \mathrm{E}$; ex Transvaal Museum; dry bush on hillside; NMSA W575/T4123 - 34 specimens; Bredasdorp, 7 km south west on R43 to Elim, bushy valley with dam; $34.5912^{\circ} \mathrm{S}, 19.9992^{\circ} \mathrm{E} ; 35 \mathrm{~m}$ a.s.1.; 13 Aug. 2014; M. Cole leg.; ELM D17983/T87 • 
COLE M.L., Revision of cyclophorid snails Chondrocyclus s.l.

15 specimens; same collection data as for preceding; ELM W3890/T88 23 specimens; Grootbos Nat. Res., Gansbaai area, Milkwood forest; $34.5421^{\circ} \mathrm{S}, 19.4153^{\circ} \mathrm{E} ; 7$ Oct. 2007; D. Herbert and L. Davis leg.; in leaf-litter; NMSA W5659/T4122 - 45 specimens; Grootbos Private Nature Reserve, between Stanford and Gansbaai, Western Cape Milkwood Forest; $34.5419^{\circ}$ S, $19.4122^{\circ}$ E; 203 m a.s.1; 13 Aug. 2014; M. Cole leg.; D18005/T89 • 6 specimens; Gansbaai dune scrub; $34.5795^{\circ} \mathrm{S}, 19.3442^{\circ} \mathrm{E}$; 13 Feb. 2005; A. Moussalli and D. Stuart-Fox leg.; in leaf-litter; NMSA W3537/T4124.

\section{Description}

SHell (Fig. 26A-F). Small, depressed, lenticular, adult diameter 3.59-5.34 mm, height 1.59-2.84 mm, diameter:height 1.68-2.37 ( $\mathrm{n}=87$ from 4 populations; variations in dimensions between populations are given in Table 4). Spire little exserted, protoconch large and mammillate (Fig. 26A). Embryonic shell (Fig. 26G) approx. 2.25 whorls, almost smooth but microscopically malleate at tip, junction between embryonic shell and teleoconch evident with development of costae on teleoconch. Teleoconch comprising just over two whorls, very convex, rapidly increasing, suture deeply impressed. Aperture circular, last whorl descending near aperture, peristome simple, continuous and free. Umbilicus wide and deep, exposing all the whorls Fig. 26C, F). Periostracum glossy and lacquer-like with lamellate axial costae at regular intervals on last whorl, 51-75 $(\mathrm{n}=22)$ in Platbos population, but vary between populations (Table 4), which produce spiral rows of simple hairs varying in different populations from approx. 4-14 on last whorl, longest at periphery and shortest around umbilicus; intervals between axial costae with approx. eight microscopic axial threads (Fig. 26H); shell bears spiral grooves corresponding with the rows of hairs (Fig. 26D-F). Shell translucent when fresh; two colour morphs present reddish brown and creamy white.

LIVING ANIMAL. Varies in colour between populations from creamy white with slight pigmentation on tentacles to very dark grey (see below).

Operculum (Fig. 26J-K). Duplex, shallowly concave; multispiral lamella of outer portion with 4.5 whorls, each step-shaped, growing edge of lamella at angle, perpendicular where it is attached to disc; fringe very short and solid, with a frayed distal edge even in fresh specimens, fringe of each whorl not fused to lamellar blade of following whorl, diameter of outer multispiral portion smaller than diameter of inner disc due to very short fringe; operculum retractile.

Radula (Fig. 26I). Rachidian with five cusps, middle one longer than two cusps on either side of it; first and second lateral teeth each with four cusps and a vestigial $5^{\text {th }}$, the third cusp from centre the largest.

PenIS (Fig. 26L). Shaft more or less cylindrical and slightly flattened dorsoventrally, distal half slightly expanded on left side, numerous annular rugae, distal end smooth, intromittent organ short.

\section{Distribution and habitat}

Western Cape, Agulhas Plain, between Gansbaai and Bredasdorp. Various forested or bushy habitats in patches of Western Cape Milkwood Forest (part of Southern Coastal forest group) (von Maltitz et al. 2003) with large trees, characterised by white milkwoods (Sideroxylon inerme), white stinkwoods (Celtis africana) and white pear (Apodytes dimidiata E. Mey. ex Arn.), including the southernmost forests in Africa (Platbos and Grootbos), dune scrub at Gansbaai and 'dry bush on hillside' (south-west of Bredasdorp); in leaf-litter (Fig. 5). 


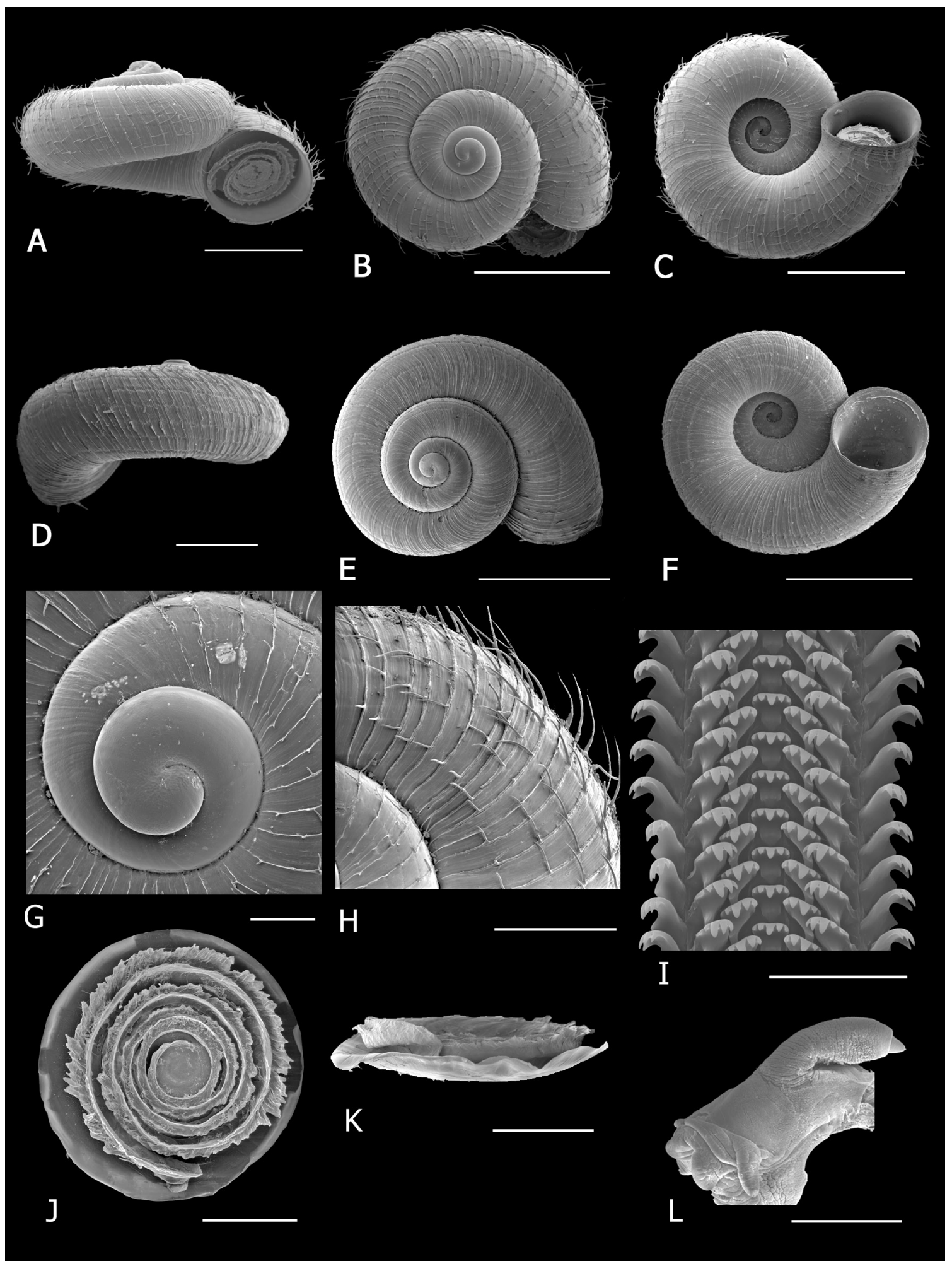

Fig. 26. Chondrocyclus kevincolei sp. nov. A. Aperture view (ELM W3615/T82). B. Dorsal view (ELM W3615/T82). C. Ventral view (ELM W3615/T82). D-F. Shell views, showing spiral grooves (NMSA W5659/T4122). G. Protoconch (ELM W3615/T82). H. Detail of axial lamellae of periostracum (ELM W3615/T82). F. Portion of radula (ELM W3615/T82). J-K. Operculum (ELM W3615/T82). L. Penis, lateral view (ELM W3615/T82). Scale bars: A-F $=2 \mathrm{~mm} ; \mathrm{G}=200 \mu \mathrm{m} ; \mathrm{H}, \mathrm{J}-\mathrm{K}=500 \mu \mathrm{m} ; \mathrm{I}=50 \mu \mathrm{m}$; $\mathrm{L}=1 \mathrm{~mm}$. 
COLE M.L., Revision of cyclophorid snails Chondrocyclus s.l.

Table 4. Measurements of Chondrocyclus kevincolei sp. nov., showing variation between populations; $\mathrm{D}=$ shell diameter, $\mathrm{H}=$ height, costae = number of axial ribs on body whorl, Avg = average.

\begin{tabular}{lccccccccccccc}
\hline Site & D max D min & Avg & H max H min & Avg & D/H max & D/H min & Avg & n & Costae & Avg & $\mathbf{n}$ \\
\hline Platbos & 5.01 & 4.43 & 4.63 & 2.59 & 2.17 & 2.41 & 2.11 & 1.74 & 1.93 & 20 & $51-75$ & 61 & 22 \\
Grootbos & 5.34 & 4.34 & 4.87 & 2.84 & 2.17 & 2.47 & 2.31 & 1.68 & 1.98 & 20 & $73-100$ & 86 & 19 \\
Gansbaai & 5.32 & 4.44 & 4.87 & 2.83 & 2.36 & 2.56 & 2.2 & 1.73 & 1.91 & 27 & $81-119$ & 98 & 19 \\
Bredasdorp & 4.76 & 3.59 & 4.22 & 2.59 & 1.59 & 2.25 & 2.37 & 1.68 & 1.88 & 20 & 52 & 52 & 1 \\
\hline
\end{tabular}

\section{Remarks}

The distinct spiral grooves on the shell of C. kevincolei sp. nov. (Fig. 26D-F) are unique among species of Chondrocyclus although there are sometimes faint traces of spiral grooves on shells of A. isipingoensis gen. et comb. nov. and $C$. langebergensis sp. nov. visible only at very high magnification. Chondrocyclus langebergensis sp. nov. differs from C. kevincolei sp. nov. in its lack of prominent spiral grooves on the shell, the spiral rows of long hairs are concentrated around the periphery, the protoconch is more strongly sculptured and the opercula differ. In C. langebergensis sp. nov., the lamellar fringe of each spiral whorl of the operculum emanates from a ridge at the base of the lamellar blade and is fused to the lamellar blade of the following whorl. The terminal fringe is long and overlaps the base when viewed from above (Fig. 25F). In C. kevincolei sp. nov. the fringe emanates from near the top of the lamellar blade and is very short and appears distinct from the following lamellar whorl; the outer saucershaped portion is smaller than the polished base (Fig. 26J). These differences together with molecular evidence, are considered to warrant recognition of at least two distinct species, one in the Langeberg Mountains and the other on the relatively low-lying coastal region of the Agulhas Plain. The Langeberge and Agulhas Plain are separated by the Breede River valley and by a belt of relatively arid vegetation, consisting mainly of Ruens Shale Renosterveld and Agulhas Limestone Fynbos (Rebelo et al. 2006), which developed in the Pliocene (Cowling et al. 2008). Molecular studies in unrelated faunal taxa also provide evidence for separate lineages in the Langeberge and the Agulhas Plain (e.g., Price et al. 2007; Moussalli et al. 2009; Gouws et al. 2010; McDonald \& Daniels 2012) and for an absence of gene flow between these areas (Myburgh \& Daniels 2015). Species of Chondrocyclus have not been recorded in the Riviersonderendberge where apparently suitable habitat exists.

There are morphological differences between populations of $C$. kevincolei sp. nov. (Table 4). The number of spiral rows of hairs is fewer in the Bredasdorp population (only 4-5 as opposed to 8-15 in the Platbos and Grootbos populations). The colour of the living animal is creamy white with only slight pigmentation of the tentacles in the Platbos population and dark grey to almost black at Bredasdorp. There were relatively large genetic divergences between populations (Cole et al. 2019). Their long branch lengths (Fig. 1) suggest isolation in shrinking refuges as arid-adapted vegetation replaced forest (see Tolley et al. 2006, 2008). Recent radiations of faunal taxa in this region are associated with adaptation to open habitats (Tolley et al. 2006; Herbert \& Moussalli 2010). Sea level changes have also had dramatic effects on vegetation of the Agulhas Plain (Linder 2003) and its biota with marine transgressions potentially restricting ancestral populations of Chondrocyclus to refuges at higher elevations and thus driving allopatric divergence or eliminating closely related taxa at lower elevations. Further studies including unsampled populations on the Agulhas Plain and additional markers may shed light on whether separate populations may warrant species status. It was, however, decided to treat these as one species pending further investigation. By contrast, C. langebergensis sp. nov. occurs in relatively stable relictual forest patches in the Langeberge and has undergone little change. 


\section{Genus Afrocyclus gen. nov. \\ urn:1sid:zoobank.org:act:0C542886-FB1A-4550-BBC2-80BBD28FA01E}

\section{Type species}

Afrocyclus isipingoensis (Sturany, 1898) gen. et comb. nov.

\section{Diagnosis}

Shell dextral, small, depressed; aperture circular, last whorl descending near aperture, peristome not thickened, continuous and free; umbilicus wide and deep, exposing all the whorls; periostracum glossy and lacquer-like with lamellate axial costae at regular intervals, usually expanded into spiral rows of hairs; operculum duplex, corneous; inner portion consists of a thin disc which grows outwards in a tight spiral, smooth on inside where it attaches to foot; fused to disc on its outer surface is a multispiral, elevated horny blade-like lamella formed by fused bristles; a fringe of fused bristles emanates from outer surface of each lamellar whorl; radula taenioglossate, two large cusps on second lateral tooth; penis lies dorsally immediately behind right tentacle and consists of a stout, muscular, cylindrical shaft, wrinkled along most of its length due to annular rugae, and a terminal, tapering intromittent organ without flagellum; seminal tube completely enclosed without seminal groove.

\section{Etymology}

The specific name is derived from 'Africa' and refers to its Afromontane occurrence.

\section{Remarks}

mtDNA data clarified that Afrocyclus gen. nov. constituted a radiation distinct from that of Chondrocyclus s.s. (Cole et al. 2019). Specimens of Afrocyclus gen. nov. can in most cases be recognised at a glance on morphological grounds, being very small, very depressed (the apex can even be concave), discoid shells with spiral rows of hairs projecting from the axial costae. This morphotype is widely distributed in latitude and altitude, occupying isolated Afromontane forest patches along the Great Escarpment from northern South Africa (Limpopo province, $\left.23^{\circ} \mathrm{S}\right)$ to the Eastern Cape $\left(32.7^{\circ} \mathrm{S}\right)$ and extending to the coast (Fig. 2). mtDNA data showed that what was previously lumped as Afrocyclus isipingoensis gen. et comb. nov. is a species complex, and within it, external morphology is relatively conserved, making it difficult to distinguish taxa by morphology alone. A. exsertus gen. et comb. nov., which occupies a narrow zone on the east coast, is strikingly different morphologically, bearing no hairs and with the axial lamellae only slightly expanded around the periphery. The operculum of the latter also deviates dramatically from the flat, fragile operculum of most specimens of Afrocyclus gen. nov. and is more robust with a rigid fringe consisting of bunches of short bristles. Phylogenetic relationships within Afrocyclus gen. nov. are not fully resolved and further molecular and morphological data from throughout its range are required to revise this complex.

\section{Key to species of Afrocyclus gen. nov.}

1. Axial lamellae slightly expanded at periphery, but not produced into hairs

A. exsertus (Melvill \& Ponsonby, 1903) gen. et comb. nov.

- Axial lamellae expanded into multiple spiral rows of hairs .... 2

2. Spiral rows of periostracal hairs include a row of very short hairs immediately below suture on body whorl. A. isipingoensis (Sturany, 1898) gen. et comb. nov.

- No spiral row of very short periostracal hairs immediately below suture. 3

3. Three spiral rows of hairs at periphery; upper edge of rachidian tooth smooth

- More than three spiral rows of hairs on body whorl; upper edge of rachidian tooth serrated. 
COLE M.L., Revision of cyclophorid snails Chondrocyclus s.l.

4. Protoconch strongly malleate A. potteri gen. et sp. nov.

- Protoconch malleate, but not strongly A. bhaca gen. et sp. nov.

Afrocyclus isipingoensis (Sturany, 1898) gen. et comb. nov.

Figs 27, 28A, 29

Cyclotus isipingoensis Sturany, 1898: 161 (type loc.: Isipingo [Penther]).

Cyclophorus minimus Melvill \& Ponsonby, 1898: 129, pl. vii, fig. 9 (type loc.: Pietermaritzburg [Burnup]).

Cyclophorus (Maizania) isipingoensis - Kobelt 1902: 149.

Chondrocyclus isipingoensis - Connolly 1939: 540. — Herbert \& Kilburn 2004: 91.

Cyclophorus minimus - Melville \& Ponsonby 1899: pl. iii, fig. 15 (operculum).

\section{Diagnosis}

Shell very small, very depressed, discoidal; periostracum with axial costae producing spiral rows of simple hairs; operculum very fragile and duplex, exterior portion very shallowly concave, with low multispiral lamella terminating in a solid fringe; rachidian tooth of radula with serrated upper edge, two large cusps on second lateral tooth.

\section{Etymology}

Named after the type locality, Isipingo, KwaZulu-Natal, South Africa.

\section{Type material examined}

\section{Holotype}

SOUTH AFRICA - KwaZulu-Natal • holotype of Cyclotus isipingoensis Sturany, 1898; in Vienna Museum, not examined; NHMW.

\section{Syntype}

SOUTH AFRICA - KwaZulu-Natal • syntype of Cyclophorus minimus Melvill \& Ponsonby, 1898; Pietermaritzburg; Burnup leg.; NHMUK 1902.10.1.7.

\section{Other material examined}

SOUTH AFRICA - Limpopo • 99 specimens; Soutpansberg, Dundee Forest; $23.017^{\circ} \mathrm{S}, 29.515^{\circ} \mathrm{E}$; 24 Jul. 1999; C. Symons leg.; sorted from leaf litter; NMSA V7513 • 77 specimens; Soutpansberg, Entabeni, Goedehoop, indigenous forest; $23.0833^{\circ} \mathrm{S}, 30.1117^{\circ} \mathrm{E} ; \pm 950 \mathrm{~m}$ a.s.l.; 20 Nov. 1997 ; D. Herbert leg.; in leaf-litter; NMSA V5658. - Mpumalanga 119 specimens; Buffelskloof Nat. Res., indigenous forest; $25.3169^{\circ} \mathrm{S}, 30.4990^{\circ} \mathrm{E}$; $1300 \mathrm{~m}$ a.s.1.; 15 Mar. 2006; J. Horn leg.; in leaf-litter; NMSA W4486. - KwaZulu-Natal -28 specimens; Ngoye Forest, lower section, coastal scarp forest; $28.8330^{\circ} \mathrm{S}$, $31.7170^{\circ} \mathrm{E} ; \pm 250 \mathrm{~m}$ a.s.1.; 6 Sep. 1997; D. Herbert leg.; in leaf litter; NMSA V5861 6 specimens; Nkandla Forest Reserve, Mdonini area, mist-belt forest; $28.7453^{\circ} \mathrm{S}, 31.1357^{\circ} \mathrm{E} ; \pm 1050 \mathrm{~m}$ a.s.l.; 21 Oct. 2003; Herbert, Bursey and Nangammbi leg.; under logs and in leaf-litter; NMSA W1103 • 58 specimens; Vernon Crookes Nat. Res., small patch of scarp forest; $30.2750^{\circ} \mathrm{S}, 30.5830^{\circ} \mathrm{E}$; $1 \mathrm{Jan} .2004$; D. Herbert leg.; in thin layer of leaf-litter on flat-topped boulder; NMSA W1441 - 28 specimens; Loteni, Yellow-Wood Cave area montane Podocarpus forest; $29.4150^{\circ} \mathrm{S}, 29.4800^{\circ} \mathrm{E} ; 1800 \mathrm{~m}$ a.s.l.; in leaf-litter; 25 Oct. 1997; D. Herbert leg.; NMSA V5752 30 specimens; Karkloof Falls, near top of gorge, Southern Mistbelt Forest; $29.4088^{\circ}$ S, 30.2840 ${ }^{\circ}$ E; 22 Jan. 2010; M. Cole leg.; ELM D16902 • 3 specimens; same collection data as for preceding; ELM W03650 1 specimen; Karkloof Nature Reserve; $29.3150^{\circ} \mathrm{S}$, $30.2500^{\circ}$ E; 1350 m a.s.1.; 23 Jan. 2010; M. Cole leg.; ELM D16903 • 17 specimens; Kenneth Stainbank 
N.R, Yellowwood Park; $29.9122^{\circ}$ S, $30.9390^{\circ}$ E; 12 Jan. 2010; M. Cole and K. Cole leg.; ELM D16897 • 34 specimens; same collection data as for preceding; 12 Apr. 2011; M. Cole, R. Daniels, L. Davis and D. Herbert leg.; ELM D16898 • 1 specimen; same collection data as for preceding; ELM W03648 • 3 specimens; same collection data as for preceding; NHMUK $20120268 \bullet 2$ specimens; same collection data as for preceding; NMW.Z.2012.065.00001 • 1 specimen; Kranskop area, Ntumjambili, indigenous forest; $28.9380^{\circ} \mathrm{S}, 30.9550^{\circ} \mathrm{E} ; \pm 900 \mathrm{~m}$ a.s.l.; 9 Aug. 1997; D. Herbert leg.; in leaf-litter; NMSA V5105 3 specimens; Kelso, dune forest behind railway station; $30.3622^{\circ} \mathrm{S}, 30.71316^{\circ} \mathrm{E} ; 24 \mathrm{~m}$ a.s.1.; 31 Oct. 2010; M. Cole leg.; ELM D17635. - Eastern Cape • 2 specimens; Mtentu, north bank, inlet $1.5 \mathrm{~km}$ upstream to first waterfall from mouth, east side of inlet; $31.2389^{\circ} \mathrm{S}, 30.0340^{\circ} \mathrm{E} ; 30 \mathrm{~m}$ a.s.l.; $13 \mathrm{Jan}$. 2012; M. Cole leg.; ELM D17086 • 1 specimen; same collection data as for preceding; ELM W03604 1 specimen; Mtentu, north bank, inlet $3 \mathrm{~km}$ upstream of mouth, west side of inlet; $31.2295^{\circ} \mathrm{S}, 30.0182^{\circ} \mathrm{E} ; 43 \mathrm{~m}$ a.s.l.; 12 Jan. 2012; M. Cole leg.; ELM D17006 • 1 specimen; same collection data as for preceding; ELM W03605 - 7 specimens; Mkambati Nature Reserve, between Mkambati and Strandloper Falls, forest on east bank of Mkambati River; $31.2738^{\circ} \mathrm{S}, 30.0236^{\circ} \mathrm{E}$; 15 Feb. 2011; M. Cole leg.; ELM D16913 • 5 specimens; same collection data as for preceding; ELM W03653 3 specimens; Mkambati, east bank Msikaba mouth; $31.3183^{\circ} \mathrm{S}, 29.9683^{\circ} \mathrm{E} ; 16$ Feb. 2011; M. Cole leg.; ELM D16914 • 1 specimen; Mkambati, Gwe Gwe forest, forest above Gwe Gwe cottages; $31.2904^{\circ} \mathrm{S}, 29.9897^{\circ} \mathrm{E}$; 5 Mar. 2001; M. Cole leg.; ELM D17004 • 1 specimen; Mkambati Nature Reserve, Daza forest; $31.3025^{\circ} \mathrm{S}, 29.9767^{\circ} \mathrm{E}$; 16 Feb. 2011; M. Cole leg.; ELM W03688 - 2 specimens; Mbotyi, Ntsubane Forest, inland of coast, accessed along KwaNyambalala River; $31.4615^{\circ} \mathrm{S}, 29.7129^{\circ} \mathrm{E}$; 3 Mar. 2003; M. Bursey leg.; ELM D17363 - 2 specimens; Xora, Kumqolo Forest, west bank of Xora river opposite Mangrove swamp; $32.1589^{\circ} \mathrm{S}, 28.9848^{\circ} \mathrm{E}$; 13 Aug. 2011; M. Cole leg.; ELM D17584 • 5 specimens; Qora, East Bank of Qora River, riverine forest; $32.4333^{\circ} \mathrm{S}, 28.6667^{\circ} \mathrm{E}$; 7 Nov. 2009; M. Cole leg.; ELM D16904 • 1 specimen; same collection data as for preceding; ELM W03651 1 specimen; same collection data as for preceding; 9 Oct. 2011; M Cole leg.; ELM D17000 • 17 specimens; Phumalanga Farm, 7 km inland of Cintsa, riverine forest on Bulura River; $32.8067^{\circ} \mathrm{S}, 28.0306^{\circ} \mathrm{E}$; $25 \mathrm{Apr}$. 2006; Bursey, Wigley and Ndibo leg.; ELM D15030 - 12 specimens; same collection data as for preceding; 12 Dec. 2008; M.Wigley; ELM D15870 - 23 specimens; same collection data as for preceding; 16 Nov. 2009; M. Cole and M. Wigley leg.; ELM D16899 - 19 specimens; same collection data as for preceding; 1 Dec. 2009; M. Wigley; ELM D16900 - 11 specimens; same collection data as for preceding; ELM W03686 - 51 specimens; same collection data as for preceding; 31 Dec. 2010; M. Cole leg.; ELM D16901 - 9 specimens; same collection data as for preceding; ELM W03649 • 1 specimen; Umtiza Nature Reserve, Tree Dassie trail on east side of Buffalo Pass; $33.0169^{\circ} \mathrm{S}, 27.8092^{\circ} \mathrm{E} ; 21$ Apr. 2006; M. Bursey leg.; ELM W03008 - 3 specimens; same collection data as for preceding; 8 Jun. 2010; M. Cole leg.; ELM D16905 - 8 specimens; same collection data as for preceding; 13 Jan. 2011; V. Ndibo, J. Glatz and R. Daniels leg.; ELM D16906 • 5 specimens; same collection data as for preceding; ELM W03652 - 5 specimens; same collection data as for preceding; 20 May 2011; M. Cole leg.; ELM D16907 • 7 specimens; same collection data as for preceding; 18 Mar. 2011; M. Cole leg.; ELM D16908 1 specimen; same collection data as for preceding; 1 Dec. 2011; M. Cole leg.; ELM D16909 • 1 specimen; Hogsback, downstream of Madonna and Child Waterfall; $32.6068^{\circ} \mathrm{S}, 26.9622^{\circ} \mathrm{E} ; 1060 \mathrm{~m}$ a.s.l.; 25 Jan. 2002; M. Bursey leg.; ELM W02835 • 1 specimen; Hogsback, Amathole Mountains, Kettlespout, forest above Hobbiton; 32.5667 S, $26.9167^{\circ}$ E; 31 Dec. 2008; M. Cole leg.; ELM D17007 • 10 specimens; Amathole Mountains, Stutterheim, Kologha Forest, near picnic site, Southern Mistbelt forest; $32.5339^{\circ} \mathrm{S}, 27.4308^{\circ}$ E; 22 Dec. 2009; M. Cole leg.; ELM D16910 • 2 specimens; Stutterheim, Kologha Forest, forest drive near Protea Hill; 32.5339 ${ }^{\circ}$ S, 27.4308 E; 26 Jan. 2010; M. Cole leg.; ELM D16911 • 3 specimens; Stutterheim, Contour path; $32.5366^{\circ}$ S, 27.3668 E; 16 Jan. 2015; M. Cole leg.; ELM D $17873 \bullet 2$ specimens; Maden Dam, 18 km N.W. of King Williams Town; $32.7333^{\circ} \mathrm{S}, 27.2833^{\circ} \mathrm{E}$; 26 Mar. 2011; D.-J. Hodgkinson leg.; ELM D16912 • 9 specimens; Fort Fordyce, kloof with watercourse and sheer krantz; $32.6893^{\circ} \mathrm{S}, 26.5121^{\circ} \mathrm{E}$; $915 \mathrm{~m}$ a.s.1.; 29 Dec. 2008; M. Cole leg.; ELM D16916 • 2 specimens; same collection data as for preceding; 6 Oct. 2009; M. Cole leg.; ELM D16961. 
COLE M.L., Revision of cyclophorid snails Chondrocyclus s.l.

\section{Description}

Specimens from Kenneth Stainbank Nature Reserve, Durban, approx. $9 \mathrm{~km}$ from the type locality Isipingo, are considered to represent the type in the following description.

SHELl (Fig. 27A-C). Very small, very depressed, discoidal, adult diameter 2.24-3.67 mm, height 1.09$1.67 \mathrm{~mm}$, diameter:height 1.9-2.31 $(\mathrm{n}=16)$ Spire almost flat, sometimes concave, usually with only the weakly mammillate, slightly tilted protoconch projecting (Fig. 27A). Embryonic shell (Fig. 28A)

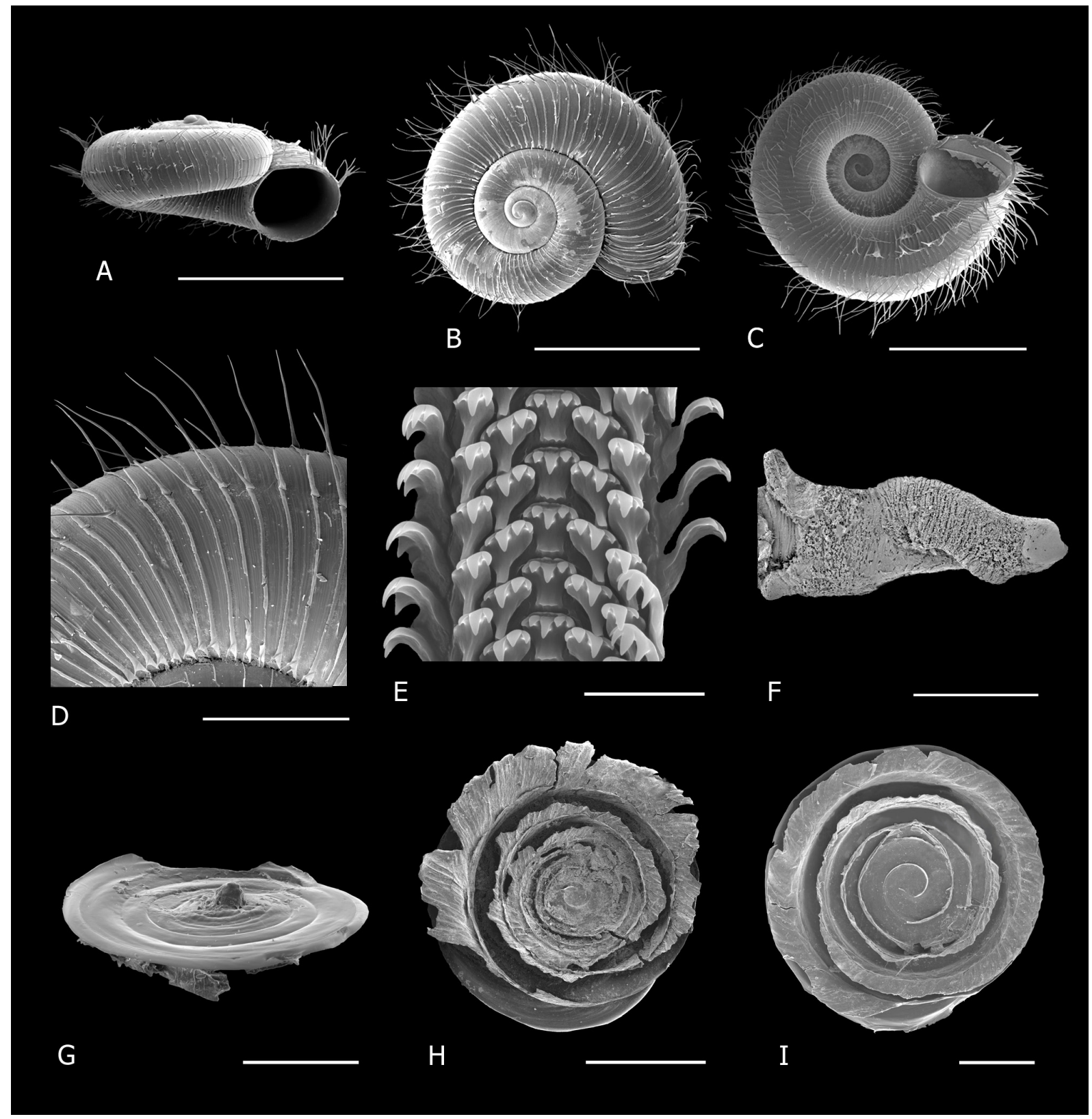

Fig. 27. Afrocyclus isipingoensis (Sturany, 1898) gen. et comb. nov. A. Aperture view (ELM W3648). B. Dorsal view (ELM W3648). C. Ventral view (ELM W3648). D. Detail of axial lamellae of periostracum (ELM D16897). E. Portion of radula (ELM W3650). F. Penis, dorsal view, showing position behind right tentacle (ELM W3652). G. Operculum, inner portion, showing tubercle (ELM W3648). H. Operculum of specimen from near type locality (ELM W3648). I. Operculum of specimen from Mpumalanga (NMSA W4486). Scale bars: A-C $=2 \mathrm{~mm} ; \mathrm{D}, \mathrm{F}-\mathrm{H}=500 \mu \mathrm{m} ; \mathrm{E}=20 \mu \mathrm{m} ; \mathrm{I}=200 \mu \mathrm{m}$. 
approx. 2.25 whorls, microscopically malleate for approx. two whorls, axial costae begin to develop at about 2.25 whorls. Teleoconch comprising just over two whorls, very rapidly increasing, convex, suture impressed. Aperture circular, last whorl descending steeply nearing aperture, peristome simple, continuous and free. Umbilicus very wide, exposing all the whorls (Fig. 27C). Periostracum glossy and lacquer-like with lamellate well-spaced axial costae at regular intervals, the average number on

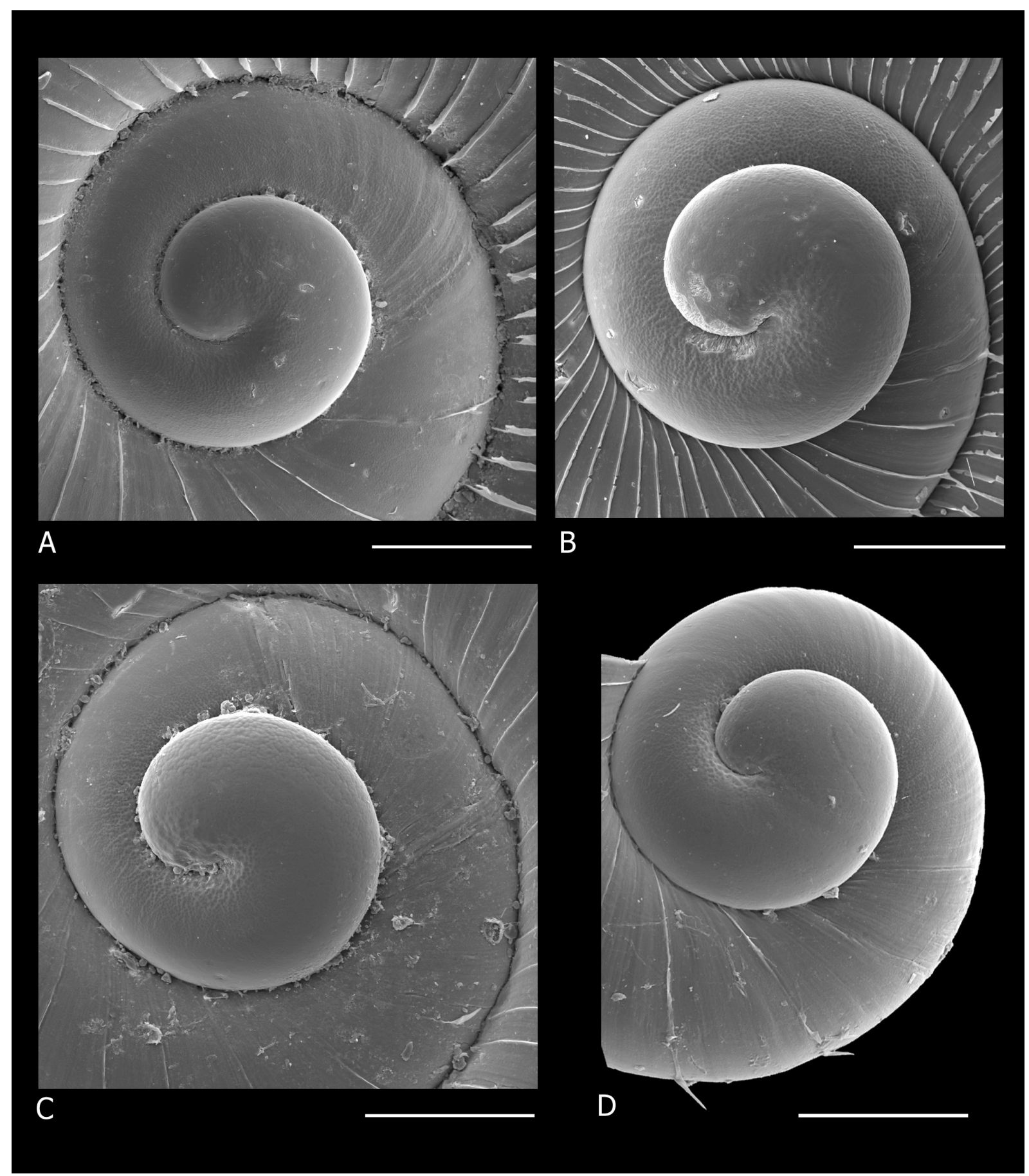

Fig. 28. Protoconch detail of species of Afrocyclus gen. nov. A. Afrocyclus isipingoensis (Sturany, 1898) gen. et comb. nov. from Durban (near type locality) (ELM W3648). B. A. oxygala gen. et sp. nov. (ELM W3647). C. A. potteri gen. et sp. nov. (ELM W4052). D. A. bhaca gen. et sp. nov. (NMSA V4889). Scale bars: A-D $=200 \mu \mathrm{m}$. 
COLE M.L., Revision of cyclophorid snails Chondrocyclus s.l.

Table 5. Measurements of populations of the Afrocyclus isipingoensis (Sturany, 1898) gen. et comb. nov. species complex; $\mathrm{D}=$ shell diameter, $\mathrm{H}=$ height, costae = number of axial ribs on body whorl, Avg = average.

\begin{tabular}{|c|c|c|c|c|c|c|c|c|c|c|c|c|c|}
\hline Site & $D$ max & D min & Avg & $H \max$ & $\mathrm{H}$ min & Avg & D/H max & $\mathrm{D} / \mathrm{H}$ min & Avg & $\mathbf{n}$ & Costae & Avg & $\mathbf{n}$ \\
\hline Kenneth Stainbank & 3.67 & 2.24 & 2.88 & 1.67 & 1.09 & 1.41 & 2.31 & 1.90 & 2.05 & 16 & $55-92$ & 75 & 14 \\
\hline Vernon Crookes & 3.26 & 2.39 & 2.89 & 1.71 & 1.07 & 1.46 & 2.24 & 1.84 & 2.00 & 13 & $52-66$ & 60 & 12 \\
\hline Upper Bulura & 3.00 & 2.24 & 2.59 & 1.68 & 1.02 & 1.24 & 2.55 & 1.67 & 2.12 & 21 & $28-40$ & 34 & 8 \\
\hline Soutpansberg & 3.10 & 2.24 & 2.75 & 1.48 & 1.12 & 1.31 & 2.38 & 1.89 & 2.09 & 10 & $59-72$ & 64 & 7 \\
\hline Lotheni & 3.16 & 2.42 & 2.82 & 1.55 & 1.14 & 1.35 & 2.29 & 2.00 & 2.10 & 6 & $40-41$ & 41 & 2 \\
\hline Ongoye & 3.63 & 2.96 & 3.22 & 1.75 & 1.08 & 1.41 & 2.75 & 2.09 & 2.30 & 14 & $61-88$ & 75 & 10 \\
\hline Nkandla & 4.11 & 2.96 & 3.52 & 1.88 & 1.48 & 1.73 & 2.18 & 1.93 & 2.03 & 3 & $68-70$ & 69 & 2 \\
\hline A. oxygala Bedford & 2.80 & 2.19 & 2.53 & 1.43 & 1.12 & 1.27 & 2.12 & 1.87 & 1.99 & 9 & $63-81$ & 69 & 7 \\
\hline A. oxygala Glen Avon & 3.00 & 2.49 & 2.76 & 1.68 & 1.32 & 1.49 & 2.04 & 1.61 & 1.86 & 20 & $76-95$ & 85 & 12 \\
\hline A. bhaca Ngele & 3.72 & 2.80 & 3.12 & 1.78 & 1.22 & 1.46 & 2.33 & 1.83 & 2.14 & 13 & $46-65$ & 53 & 10 \\
\hline A. bhaca Mount Frere & 2.75 & 2.49 & 2.65 & 1.22 & 0.97 & 1.11 & 2.58 & 2.21 & 2.39 & 6 & $48-58$ & 54 & 5 \\
\hline A. potteri Langeni & 3.51 & 2.19 & 3.03 & 1.68 & 1.02 & 1.36 & 2.41 & 2.04 & 2.23 & 14 & $47-67$ & 55 & 7 \\
\hline A. potteri Moonstone & 2.82 & 2.17 & 2.44 & 1.38 & 1.03 & 1.22 & 2.20 & 1.70 & 2.01 & 31 & $31-45$ & 37 & 17 \\
\hline
\end{tabular}

last whorl varying between 55 and 92 (Table 5), which produce 10-12 spiral rows of simple hairs, longest at periphery (four rows) with approx. five-seven rows between periphery and umbilicus, the latter becoming progressively shorter nearer the umbilicus, and one very short row immediately below the suture; intervals between costae usually with six to nine microscopic axial threads (Fig. 27D). Shell translucent when fresh.

Operculum (Fig. 27E-F). Very fragile and duplex, outer portion consists of multispiral lamella with five-six whorls, height of lamellar blade very low thus operculum is very shallowly concave to almost flat, thickened horizontal ridge on lamellar blade just above disc surface; long fringe of fused bristles emanates from this ridge, fused to blade and then curving outwards, leaving no furrow between fringe and vertical portion of blade, fringe of each whorl fused to lamella of following whorl, fringe of outer whorl fairly long and overlaps disc slightly; inner portion of operculum is a thin disc, in some populations side of disc facing body has a prominent tubercle or swelling in centre (Fig. 27F).

RADULA (Fig. 27G). Rachidian with five cusps, central one very long, outermost two very small to almost vestigial, cusps set a little distance below 'top' of tooth, top edge serrated; first lateral tooth with four cusps and a vestigial fifth, third cusp (from centre) largest; second lateral tooth with two large cusps, second cusp (from centre) largest, a third small cusp and a vestigial fourth.

PENIS (Fig. 27H). Shaft more or less cylindrical and laterally expanded on left side about midway down the shaft.

\section{Distribution and habitat}

This species complex is widely distributed throughout the eastern region of South Africa, from Soutpansberg mountains in Limpopo Province to the Amathole mountains in the Eastern Cape; from the coast to the Drakensberg foothills (1800 m) (Fig. 29).

Indigenous forest of several classification types (Mucina \& Geldenhuys 2006): Southern and Northern Coastal Forest, Scarp Forest, Southern and Northern Mistbelt Forest, Northern Afrotemperate Forest, and Albany Thicket (Kowie Thicket) (Hoare et al. 2006); in leaf-litter. 


\section{Remarks}

Selected populations from across the range of this lineage were sampled for the molecular study and morphological examination and there is compelling evidence that $A$. isipingoensis gen. et comb. nov. is a species complex rather than one widespread species. Until further study is undertaken the name A. isipingoensis gen. et comb. nov. is applied to all populations with the exception of the three new species described below. Differences in the density of axial lamellae, the number and position of spiral rows of hairs, the length of the hairs, the density of microscopic axial threads between the lamellae and the strength of protoconch sculpture will need to be evaluated in conjunction with molecular evidence from more comprehensive coverage of the range of the complex.

The phylogeny inferred suggests that populations from the western end of the range (Somerset East and Bedford) belong to a distinct lineage (A. oxygala gen. et sp. nov.). There was also a well-supported lineage in montane areas between the coast and Great Escarpment in the central Transkei (A. potteri gen. et sp. nov.) and another lineage occurring in relatively close proximity in the north-eastern Transkei (A. bhaca gen. et sp. nov.). The population from near the type locality had one row of extremely short hairs on lamellate costae immediately below the suture, and a gap with no hairs between this and the four rows of very long hairs near the periphery (Fig. 27D). Afrocyclus oxygala gen. et sp. nov. (Fig. 30D), A. potteri gen. et sp. nov. (Fig. 31D-E) and A. bhaca gen. et sp. nov. (Fig. 32D) lacked the extremely short row just below the suture.

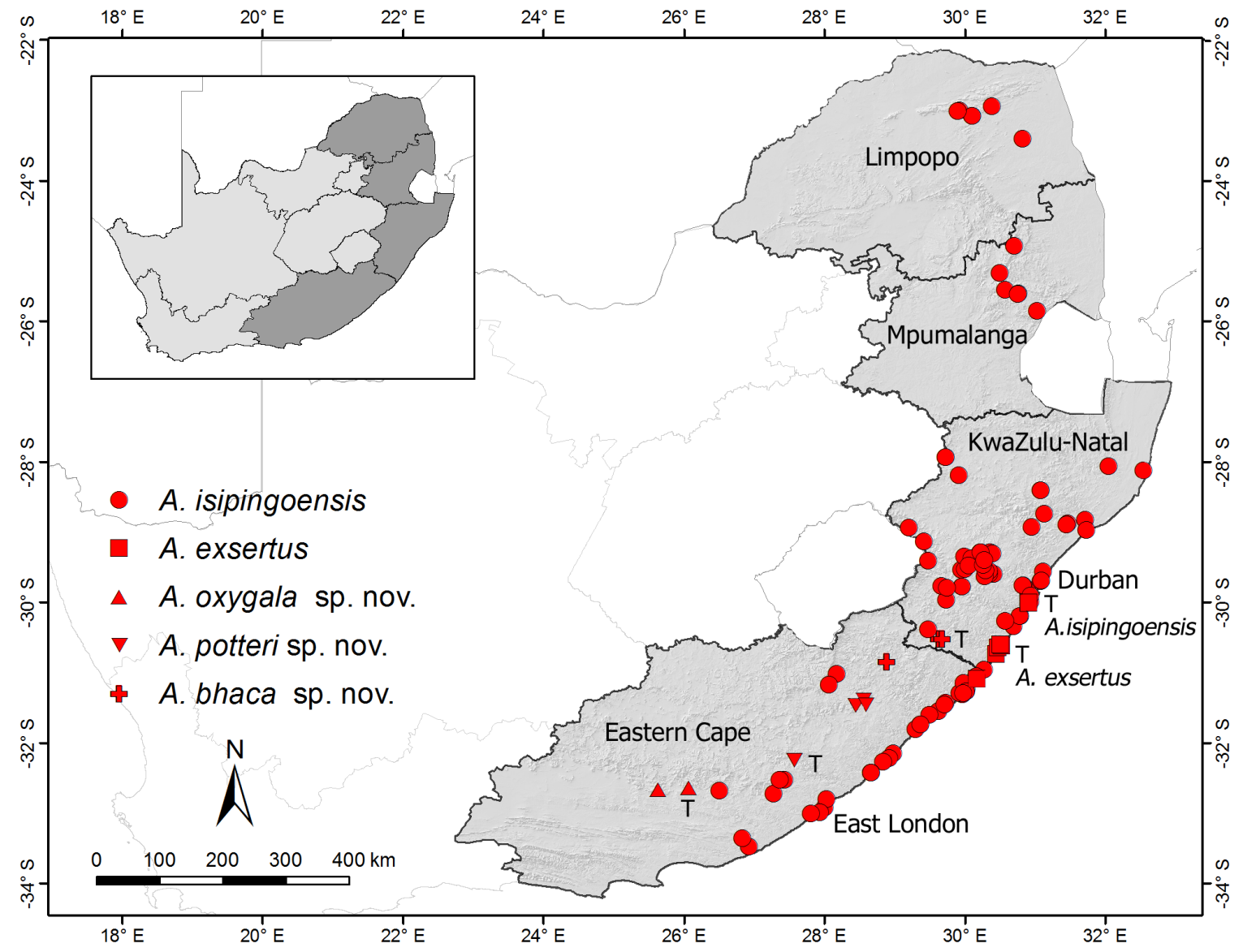

Fig. 29. Distribution map of Afrocyclus gen. nov. T indicates type localities. Provinces and major cities are labelled. 
COLE M.L., Revision of cyclophorid snails Chondrocyclus s.l.

The rachidian tooth of the radula is unusual in having a serrated upper edge and the cusps are set a little distance below the 'top' of tooth. Afrocyclus isipingoensis gen. et comb. nov. (Fig. 27G), A. exsertus gen. et comb. nov. (Fig. 33G), A. potteri gen. et sp. nov. (Fig. 31G) and A. bhaca gen. et sp. nov. (Fig. 32E) showed this feature while the upper edge of the rachidian tooth of $A$. oxygala gen. et sp. nov. (Fig. 30G) was not serrated as in species of Chondrocyclus s.s.

\author{
Afrocyclus oxygala gen. et sp. nov. \\ urn:lsid:zoobank.org:act:7B7B852C-8B49-494A-A652-B313EBDC6372
}

Figs 11A-B, 28B, 29, 30

Chondrocyclus isipingoensis - Connolly 1939: 540. — Herbert \& Kilburn 2004: 91.

\title{
Diagnosis
}

Shell very small, depressed, discoidal; periostracum with axial costae producing spiral rows of simple hairs; operculum very fragile and duplex, exterior portion very shallowly concave, with low multispiral lamella terminating in a solid fringe, radula with two large cusps on second lateral tooth and rachidian tooth without serrated upper edge.

\section{Etymology}

The specific name is derived from the Greek 'oxygala', meaning 'sour milk', a translation of the name of the type locality, Maasstrom.

\section{Type material examined}

\section{Holotype}

SOUTH AFRICA - Eastern Cape • Bedford, Maasstrom Farm, forest in kloof; $32.6830^{\circ} \mathrm{S}, 26.0830^{\circ} \mathrm{E}$; 24 Jan. 2011; M. Cole, R. Daniels and V. Ndibo leg.; NMSA P0638/T4153. (Fig. 11A-B)

\section{Paratypes}

SOUTH AFRICA - Eastern Cape • 9 specimens; same collection data as for holotype; ELM D16895/ T151 3 specimens; same collection data as for holotype; ELM W03646/T172 1 specimen; same collection data as for holotype; NHMUK 20160078 1 specimen; Bedford, Maasstrom Farm, forest in kloof; $32.6830^{\circ} \mathrm{S}, 26.0830^{\circ} \mathrm{E}$; 1 Jan. 2007; M. Bursey leg.; ELM D15108/T153 - 1 specimen; same collection data as for preceding; ELM W3122/T154 • 5 specimens; Bedford, Maasstrom Forest; J. Farquhar leg.; NMSA V6684/T5154 • 40 specimens; Somerset East, Glen Avon Falls, forest beside base of falls; $32.6770^{\circ} \mathrm{S}, 25.6368^{\circ} \mathrm{E} ; 19 \mathrm{Jan} .2002$; D. Herbert leg.; in leaf-litter; NMSA W0754/T4155 • 72 specimens; Somerset East, Glen Avon, downstream of falls; $32.6770^{\circ} \mathrm{S}, 25.6367^{\circ} \mathrm{E} ; 25 \mathrm{Jan} .2011$; M. Cole, V. Ndibo and R. Daniels leg.; ELM D16896/T155 • 50 specimens; same collection data as for preceding; ELM W03647/T156 - 3 specimens; same collection data as for preceding; NHMUK 20160076 • 2 specimens; same collection data as for preceding; NHMUK 20160077 • 3 specimens; same collection data as for preceding; RMNH.MOL.338285 4 specimens; same collection data as for preceding; NMW.Z.2016.003.00003.

\section{Description}

SHELL (Fig. 30A-C). Very small, depressed, discoidal, adult diameter $2.19-3.0 \mathrm{~mm}$, height $1.12-1.68 \mathrm{~mm}$, diameter:height 1.61-2.12 $(\mathrm{n}=29)$. Spire low, each whorl just rising above the next, apex acutely mammillate and tilted (Fig. 30A). Embryonic shell (Fig. 28B) just over 2.25 whorls, microscopically malleate, junction between embryonic shell and teleoconch evident with termination of malleation. Teleoconch comprising just over two whorls, very rapidly increasing, convex, suture impressed. 
Aperture circular, last whorl descending steeply nearing aperture, peristome simple, continuous and free. Umbilicus very wide, exposing all the whorls (Fig. 30C). Periostracum glossy and lacquer-like with lamellate axial costae at regular intervals (Fig. 30D), the average number on last whorl varying between 63 and 95 (Table 5), which produce three spiral rows of long, simple hairs at periphery; intervals between costae usually with approx. five microscopic axial threads. Shell translucent when fresh.

Operculum (Fig. 30E-F). Very fragile and duplex, outer portion consists of multispiral lamella with five-six whorls, height of lamellar blade very low thus operculum is very shallowly concave to almost flat, thickened horizontal ridge on lamellar blade just above disc surface; long fringe of fused bristles emanates from this ridge, fused to blade and then curving outwards, leaving no furrow between fringe and vertical portion of blade, fringe of each whorl does not appear to be fused to lamella of following whorl, fringe of outer whorl fairly long and overlaps disc slightly; inner portion of operculum is a thin disc, without a prominent tubercle in centre.

Radula (Fig. 30G). Rachidian with five cusps, central one very long, outermost two relatively short, first lateral tooth with four cusps and a vestigial fifth, third cusp (from centre) very long; second lateral tooth with two large cusps, second cusp (from centre) larger, a third small cusp and a vestigial fourth.

PeNIS (Fig. 30H-I). Relatively short, shaft more or less cylindrical.

\section{Distribution and habitat}

Eastern Cape, southern end of Great Escarpment, in Eastern Cape Escarpment Thicket (Hoare et al. 2006) associated with river valleys (Fig. 29).

\section{Remarks}

The molecular phylogeny suggests that $A$. oxygala gen. et sp. nov. belongs to a lineage distinct from all other populations of Afrocyclus gen. nov. sampled (Fig. 1) but further study is required to resolve phylogenetic relationships between $A$. oxygala gen. et sp. nov. and other species of Afrocyclus gen. nov.

The species is readily distinguished by having only three rows of long hairs on lamellate costae round the periphery (although in adults the hairs were usually worn off), while $A$. isipingoensis gen. et comb. nov. has four rows around the periphery. A. oxygala gen. et sp. nov. lacks the additional spiral rows of hairs present in $A$. isipingoensis gen. et comb. nov.: one row of very short hairs below the suture and approx. five-seven rows of shorter hairs between the periphery and umbilicus. A. oxygala gen. et sp. nov. has a higher spire (and consequently deeper umbilicus) and a more strongly sculptured protoconch (Fig. 28B). The operculum has a smooth inner disc without a tubercle in its centre. The radula more closely resembles those of species in the Southern-Eastern Cape clade (smooth upper edge of rachidian and two large cusps on second lateral tooth) than those of other specimens of Afrocyclus gen. nov. examined. The penis of $A$. oxygala gen. et sp. nov. is relatively short.

This lineage occurs at the western extremity of the distribution of gen. nov. and the populations at Somerset East and Bedford are on opposite sides of the upper Great Fish River Valley (Fig. 29). Although considered an arid barrier for dispersal of montane taxa (Weimarck 1941; Stuckenberg 1962), this valley has not consistently been a major hindrance to connectivity along this region of the Great Escarpment (Clark et al. 2010) and may have been an area of persistence of thicket during the Last Glacial Maximum (24000 to 18000 years ago) (Potts et al. 2012) and perhaps prior maxima. 


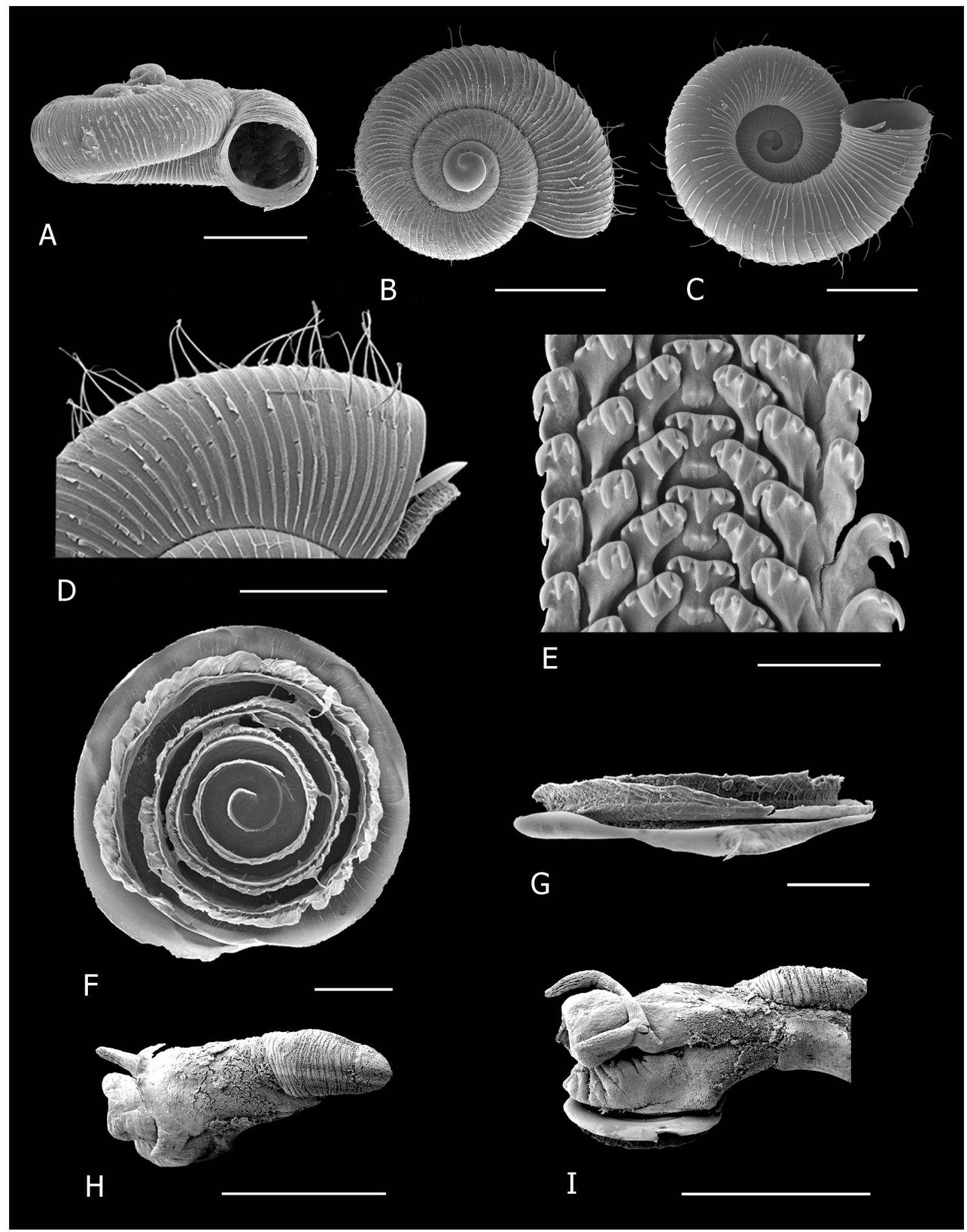

Fig. 30. Afrocyclus oxygala gen. et sp. nov. A. Aperture view (ELM D16896). B. Dorsal view (ELM W3647). C. Ventral view (ELM W3647). D. Portion of juvenile shell, showing detail of periostracum (ELM W3647). E. Portion of radula (ELM W3646). F-G. Operculum (ELM W3647). H-I. Penis, showing position, dorsal and lateral views (ELM W3647). Scale bars: A-D, H = $1 \mathrm{~mm} ; \mathrm{E}=20 \mu \mathrm{m}$; $\mathrm{F}-\mathrm{G}=200 \mu \mathrm{m} ; \mathrm{I}=500 \mu \mathrm{m}$. 


\section{Afrocyclus potteri gen. et sp. nov. urn:lsid:zoobank.org:act:AD0079D7-605D-45DE-BCB6-3FF2E9E9349D}

Figs 11C-D, 28C, 29, 31

\section{Diagnosis}

Shell very small, depressed, discoidal; periostracum with widely-spaced axial costae producing spiral rows of simple hairs; protoconch strongly malleate; operculum very fragile and duplex, exterior portion very shallowly concave, with low multispiral lamella terminating in a solid fringe, radula with two large cusps on second lateral tooth and rachidian tooth with serrated upper edge.

\section{Etymology}

Named for Neil Potter, for his interest in and conservation of flora and fauna on his farms in the Kei River Valley. His family, Carmen, Dylan and Morgan, assisted with fieldwork.

\section{Type material examined}

\section{Holotype}

SOUTH AFRICA - Eastern Cape - Moonstone Farm, Kei River valley, NNE of Stutterheim, top of mountain, forest at base of sheer krantz; $32.2565^{\circ} \mathrm{S}, 27.5688^{\circ} \mathrm{E} ; 1175 \mathrm{~m}$ a.s.1.; 24 Apr. 2018; M. Cole and N. Potter leg.; in leaf litter; NMSA P1125/T4283. (Fig. 11C-D)

\section{Paratypes}

SOUTH AFRICA - Eastern Cape 13 specimens; same collection data as for holotype; ELM D18354/ T182 - 5 specimens; same collection data as for holotype; ELM W4052/T183 • 1 specimen; same collection data as for holotype; NMSA P1143/T4314 • 1 specimen; same collection data as for holotype; NHMUK 20180585 • 1 specimen; same collection data as for holotype; NHMUK 20180586 • 1 specimen; same collection data as for holotype; NMW.Z.2019.004.00005 • 1 specimen; same collection data as for holotype; RMNH.MOL.340757 - 13 specimens; same collection data as for holotype; 7 Apr. 2005; M. Bursey leg.; ELM D14656/T184 - 2 specimens; same collection data as for holotype; NMSA P1142/T4313 • 1 specimen; same collection data as for holotype; NMW.Z.2019.004.00004 • 1 specimen; same collection data as for holotype; RMNH.MOL.340756 11 specimens; same collection data as for holotype; 19 Dec. 2012; M. and K. Cole leg.; ELM D17097/T185 • 10 specimens; Kambi Forest, Langeni area; $31.4662^{\circ} \mathrm{S}, 28.6156^{\circ} \mathrm{E} ; 19 \mathrm{Jan} .2017$; M. Cole and R. Cawood leg.; ELM D18233/ T186 3 specimens; Kambi Forest, Langeni area; $31.4680^{\circ} \mathrm{S}, 28.5893^{\circ} \mathrm{E} ; 25$ Jan. 2013; M. Cole and V. Ndibo leg.; ELM D17151/T187 • 13 specimens; Kambi Forest, west of Mthatha, Afromontane forest; 31.28.1 ${ }^{\circ} \mathrm{S}, 28.35 .4^{\circ} \mathrm{E}$; $1200 \mathrm{~m}$ a.s.1., 24 Apr. 1999; D. Herbert leg.; in leaf litter; NMSA V7161/T4289 • 2 specimens; Baziya Block A(3); $31.5701^{\circ} \mathrm{S}, 28.4224^{\circ} \mathrm{E}$; 15 Jan. 2017; M. Cole and R. Cawood leg.; ELM D18183/T188 • 1 specimen; Baziya Forest, west of Mthatha; $31.32^{\circ} \mathrm{S}, 28.24^{\circ} \mathrm{E} ; 15 \mathrm{Jul} .2001$; C. Symes leg.; in leaf litter; NMSA V9359/T4288 2 specimens; Baziya Forest, Langeni area, large block of indigenous forest; $31.31 .250^{\circ} \mathrm{S}, 28.24 .738^{\circ} \mathrm{E} ; 19 \mathrm{Feb} .2006$; D. Herbert and L. Davis leg.; in leaf litter; NMSA W3973/T4294 • 2 specimens; Langeni; $31.47^{\circ}$ S, 28.45 E; 18 Feb. 2006; M. Bursey leg.; ELM D14713/T189 - 1 specimen; Langeni, Nocu forest, large block of indigenous forest; $31.4222^{\circ} \mathrm{S}$, $28.4984^{\circ}$ E; 840 m a.s.l.; 18 Feb. 2006; D. Herbert and L. Davis leg.; in leaf-litter; NMSA W3929/T4293• 2 specimens; same collection data as for preceding; 18 Feb. 2006; M. Bursey leg.; ELM D14704/T190 • 3 specimens; Langeni, Jenca Valley, small piece of indigenous forest in rocky valley, above escarpment; 31.21.956 ${ }^{\circ}$ S, 28.33.436 ${ }^{\circ}$ E; ca 1420 m a.s.1.; 18 Feb. 2006; D. Herbert and L. Davis leg.; in leaf-litter; NMSA W3933/T4292 • 2 specimens; same collection data as for preceding; NMW.Z.2019.004.00006 • 4 specimens; same collection data as for preceding; M. Bursey leg.; ELM D14710/T191 1 specimen; Langeni, below aerial road; $31.4754^{\circ} \mathrm{S}, 28.4418^{\circ} \mathrm{E}$; 18 Mar. 2006; M. Bursey leg.; ELM D14811/T192 • 14 specimens; Langeni Forest west of Umtata, afromontane forest; $31.23 .9^{\circ} \mathrm{S}, 28.33 .3^{\circ} \mathrm{E} ; 1200 \mathrm{~m}$ a.s.1.; 24 Apr. 1999; D. Herbert leg.; in leaf-litter; NMSA V7063/T4290 • 2 specimens; same collection data as for preceding; RMNH.MOL.340758 13 specimens; same collection data as for preceding; $31.24 .3^{\circ} \mathrm{S}$, 
COLE M.L., Revision of cyclophorid snails Chondrocyclus s.l.

28.32.7 E; NMSA V7178/T4291 • 3 specimens; same collection data as for preceding; NHMUK 20180587.

\section{Other material examined}

SOUTH AFRICA - Eastern Cape - 1 specimen; Baziya Block B(2); $31.5433^{\circ} \mathrm{S}, 28.4196^{\circ} \mathrm{E}$; 14 Jan. 2017; M. Cole and R. Cawood leg.; ELM D18163.

\section{Description}

Shell (Fig. 31A-C). Very small, depressed, discoidal, adult diameter 2.17-3.51 mm, height $1.02-$ $1.68 \mathrm{~mm}$, diameter:height 1.7-2.41 ( $\mathrm{n}=45)$. Spire low, each whorl just rising above the next, apex mammillate and slightly tilted (Fig. 31A). Embryonic shell (Fig. 28C) just under 2.5 whorls, strongly malleate, junction between embryonic shell and teleoconch evident with development of axial costae on teleoconch. Teleoconch comprising two whorls, very rapidly increasing, convex, suture impressed. Aperture circular, last whorl descending steeply nearing aperture, peristome simple, continuous and free. Umbilicus very wide, exposing all the whorls (Fig. 31C). Periostracum glossy and lacquer-like with well-spaced lamellate axial costae at regular intervals, the number on last whorl varying between 31 and 67 (Table 5), which produce six-ten spiral rows of simple hairs; intervals between costae with approx. 15-20 microscopic axial threads. Shell translucent when fresh.

OperCulum (Fig. 31F). Very fragile and duplex, outer portion consists of multispiral lamella with 5.25 whorls, height of lamellar blade very low and thus operculum is very shallowly concave to almost flat, thickened horizontal ridge on lamellar blade just above disc surface; long fringe of fused bristles emanates from this ridge, fused to blade and then curving outwards, leaving no furrow between fringe and vertical portion of blade, fringe of each whorl does not appear to be fused to lamella of following whorl, fringe of outer whorl does not overlap the disc; inner portion of operculum is a thin disc, without a prominent tubercle in centre.

RADULA (Fig. 31G). Rachidian with five cusps set a little distance below upper edge of tooth, upper edge slightly serrated, central cusp very long; first lateral tooth with four cusps and a vestigial fifth, third cusp (from centre) very long; second lateral tooth with two large cusps, second cusp (from centre) larger, a third small cusp and a vestigial fourth.

PenIs (Fig. 31H). Shaft more or less cylindrical.

\section{Distribution and habitat}

Medium altitude forests of the 'first escarpment' in the interior of the Transkei region of the Eastern Cape and Kei River Valley. Transkei Mistbelt Forest (von Maltitz et al. 2003) (Fig. 29).

\section{Remarks}

Populations in the geographically disjunct areas of central Transkei and Kei River Valley formed a very well-supported clade, although populations in the two areas were morphologically distinct (Fig. 31DE). Specimens from the type locality on the west side of the Kei River Valley are readily distinguished by very widely-spaced axial costae and relatively short periostracal hairs. The protoconchs of specimens from both areas were relatively large (approx. $750 \mu \mathrm{m}$ ) and more strongly mammillate than in any other species of Afrocyclus gen. nov.

It has been suggested that recent migration may have been facilitated by more extensive forest cover along the inland Transkei mistbelt during the Holocene altithermal (Hughes et al. 2005) and perhaps some of the more recent altithermals of the Quaternary climatic oscillations (Partridge 1993; Partridge et al. 1999). 


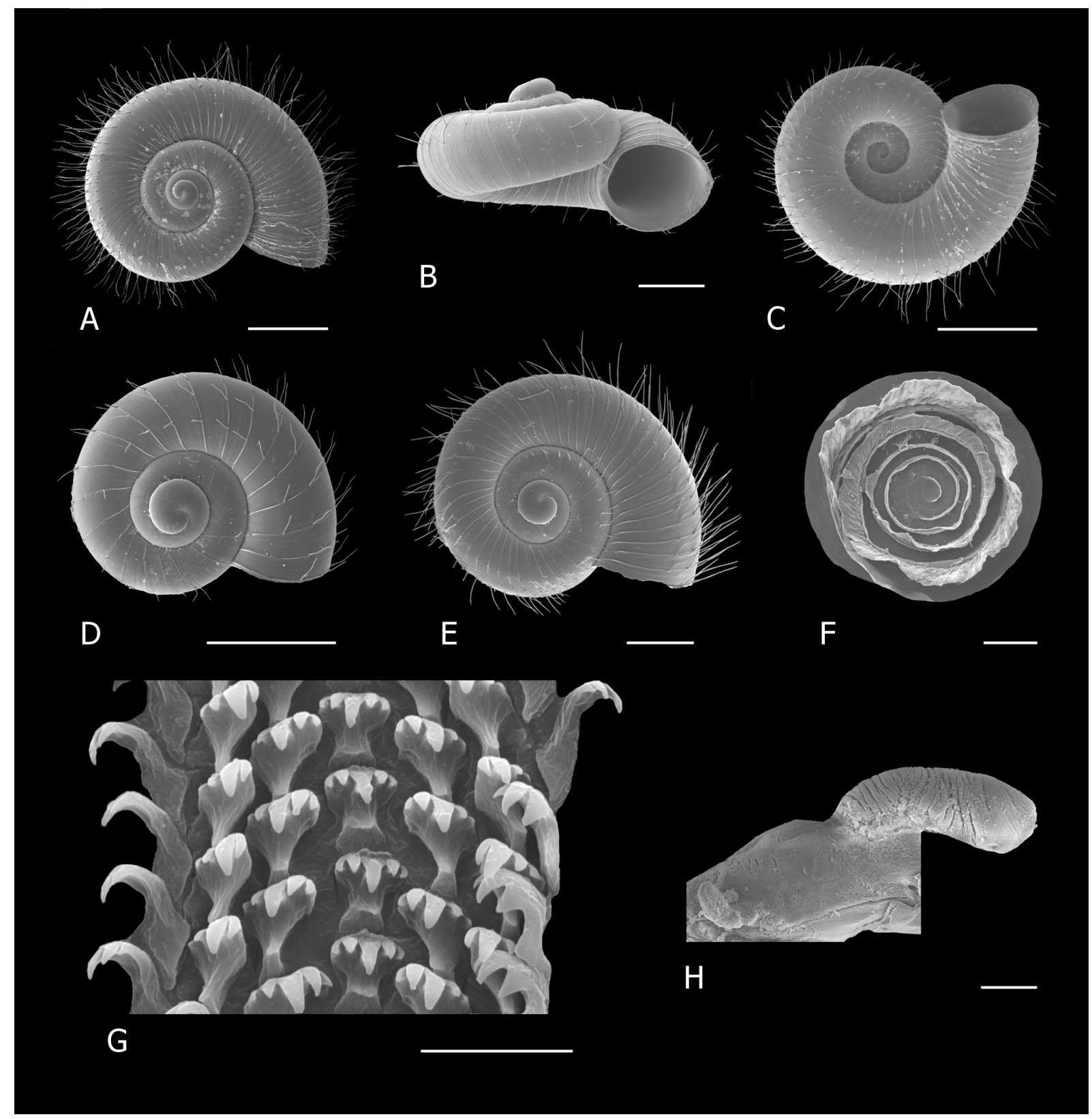

Fig. 31. Afrocyclus potteri gen. et sp. nov. A. Dorsal view (ELM D14713). B. Aperture view (ELM W4052). C. Ventral view (ELM D18233). D-E. Juveniles to show variation in detail of axial lamellae of periostracum from different populations: D. Juvenile from type locality (ELM W4052). E. Juvenile from Langeni (ELM D17151). F. Operculum (ELM W4052). G. Portion of radula (ELM W3933). H. Penis, lateral view (ELM W4052). Scale bars: A, C = $1 \mathrm{~mm} ; \mathrm{B}, \mathrm{D}-\mathrm{E}=500 \mu \mathrm{m} ; \mathrm{F}, \mathrm{H}=200 \mu \mathrm{m} ; \mathrm{G}=20 \mu \mathrm{m}$. 
COLE M.L., Revision of cyclophorid snails Chondrocyclus s.l.

\section{Afrocyclus bhaca gen. et sp. nov. urn:lsid:zoobank.org:act:24F095DF-C063-42C8-BA94-4E793764C8B0}

Figs 11E-F, 28D, 29, 32

\section{Diagnosis}

Shell very small, depressed, discoidal; periostracum with axial costae producing spiral rows of simple hairs; operculum very fragile and duplex, exterior portion very shallowly concave, with low multispiral lamella terminating in a solid fringe, radula with two large cusps on second lateral tooth and rachidian tooth with slightly serrated upper edge.

\section{Etymology}

Named for the amaBhaca people who inhabit the Mount Frere and Umzimkhulu regions, having fled from King Shaka Zulu during the wars of turmoil in the 1820s under King Madzikane.

\section{Type material examined}

\section{Holotype}

SOUTH AFRICA - KwaZulu-Natal • Ngele Forest, $26 \mathrm{~km}$ east of Kokstad, large forest patch divided by N2 national road, Red Trail on the west side of N2 approx. $0.5 \mathrm{~km}$ NNW of Ngele Forest Inn hotel; $30.5331^{\circ} \mathrm{S}, 29.6827^{\circ} \mathrm{E}$; $1234 \mathrm{~m}$ a.s.1.; 15 Apr. 2015; M. and K. Cole leg.; NMSA P1124/T4282. (Fig. 11E-F)

\section{Paratypes}

SOUTH AFRICA - KwaZulu-Natal • 1 specimen; same collection data as for holotype ELM D17891/ T177 3 specimens; same collection data as for holotype; ELM W03855/T178 2 specimens; same collection data as for holotype; 3 Oct. 2018; M. Cole leg.; ELM D18357/T194 • 1 specimen; same collection data as for holotype; ELM W04055/T193 - 1 specimen (dry shell and body in ethanol); same collection data as for holotype; NHMUK 20180583 - 2 specimens; Ngele Forest, Green Trail, small patch of forest approx. $0.5 \mathrm{~km} \mathrm{SW}$ of hotel; $30.5406^{\circ} \mathrm{S}, 29.6802^{\circ} \mathrm{E} ; 1208 \mathrm{~m}$ a.s.1.; 7 Apr. 2015; M. and K. Cole leg.; ELM D17900/T179 5 specimens; Ngele Forest, near Kokstad, mistbelt Podocarpus forest; $30.31 .5^{\circ} \mathrm{S}, 29.41 .5^{\circ} \mathrm{E}$; $\pm 1350 \mathrm{~m}$ a.s.1.; $14-15$ Nov. 1995; D. Herbert and L. Davis leg.; in leaf litter; NMSA V2075/T4284 6 specimens; same collection data as for preceding; $30.31 .857^{\circ} \mathrm{S}$, 29.41.076 E; 3 Mar. 1997; D. Herbert leg.; in leaf litter and under logs; NMSA V8277/T4285 • 2 specimens; same collection data as for preceding; NHMUK 20180584 2 specimens; same collection data as for preceding; NMW.Z.2019.004.0007 - 4 specimens; same collection data as for preceding; sorted from dried leaf-litter sample; NMSA V4889/T4286 2 specimens; same collection data as for preceding; RMNH.MOL.340759 1 specimen; Ngele Forest, near Kokstad, mistbelt Podocarpus forest; 30.32 ${ }^{\circ}$ S, 29.38 E; 27 Mar. 1998; C. Symes leg.; in leaf litter; NMSA V6886/T4287 - Eastern Cape • 8 specimens; Mount Frere, just south of Buffalo Nek village, $10 \mathrm{~km} \mathrm{NW}$ of Mount Frere; $30.8548^{\circ} \mathrm{S}$, $28.8930^{\circ} \mathrm{E}$; $1466 \mathrm{~m}$ a.s.1.; 7 Apr. 2015; M. Cole leg.; in leaf litter; ELM D17893/T180 • 3 specimens; same collection data as for preceding; ELM W03856/T181.

\section{Other material examined}

SOUTH AFRICA - KwaZulu-Natal • 7 specimens; Ngele Forest, mist-belt Podocarpus forest; $30^{\circ} 32^{\prime}$ S, $29^{\circ} 38^{\prime} \mathrm{E}$; $\pm 1350 \mathrm{~m}$ a.s.1.; 17 Feb. 1997; D. Barraclough leg.; sorted from dried leaf-litter sample; NMSA V4867. - Eastern Cape - 2 specimens; Mount Frere, just south of Buffalo Nek village, $10 \mathrm{~km} \mathrm{NW}$ of Mount Frere; $30.8548^{\circ} \mathrm{S}, 28.8930^{\circ} \mathrm{E}$; $1466 \mathrm{~m}$ a.s.1.; 4 Oct. 2018; M. Cole leg.; in leaf litter; ELM D18356 7 specimens; same collection data as for preceding; ELM W04054. 


\section{Description}

SHELl. Very small, very depressed, discoidal, adult diameter $2.49-3.72 \mathrm{~mm}$, height $0.97-1.78 \mathrm{~mm}$, diameter:height 1.83-2.58 $(\mathrm{n}=19)$ (Fig. 32A-C). Spire almost flat, sometimes concave, usually with only the weakly mammillate protoconch projecting (Fig. 32A). Embryonic shell (Fig. 28D) just over two whorls, microscopically malleate, junction between embryonic shell and teleoconch evident with development of axial costae on teleoconch. Teleoconch comprising two whorls, very rapidly increasing, convex, suture impressed. Aperture circular, last whorl descending steeply nearing aperture, peristome simple, continuous and free. Umbilicus very wide, exposing all the whorls. Periostracum glossy and lacquer-like with well-spaced lamellate axial costae at regular intervals, the number on last whorl varying between 46 and 65 (Table 5), which produce spiral rows of simple hairs varying from 4-15 on last whorl (4-5 and 14-15 respectively in the two populations examined) (Fig. 32B, D), longest at periphery and shortest around umbilicus; intervals between costae with approx. nine microscopic axial threads. Shell translucent when fresh.

Operculum (Fig. 32E). Very fragile and duplex, outer portion consists of multispiral lamella with five whorls, height of lamellar blade very low thus operculum is very shallowly concave to almost flat, thickened horizontal ridge on lamellar blade just above disc surface; starting just after whorl 3 a long fringe of fused bristles emanates from this ridge, fused to blade and then curving outwards, leaving a furrow between fringe and vertical portion of blade, fringe of each whorl is not fused to lamella of following whorl, fringe of outer whorl extends to edge of disc; inner portion of operculum is a thin disc, without a prominent tubercle in centre.

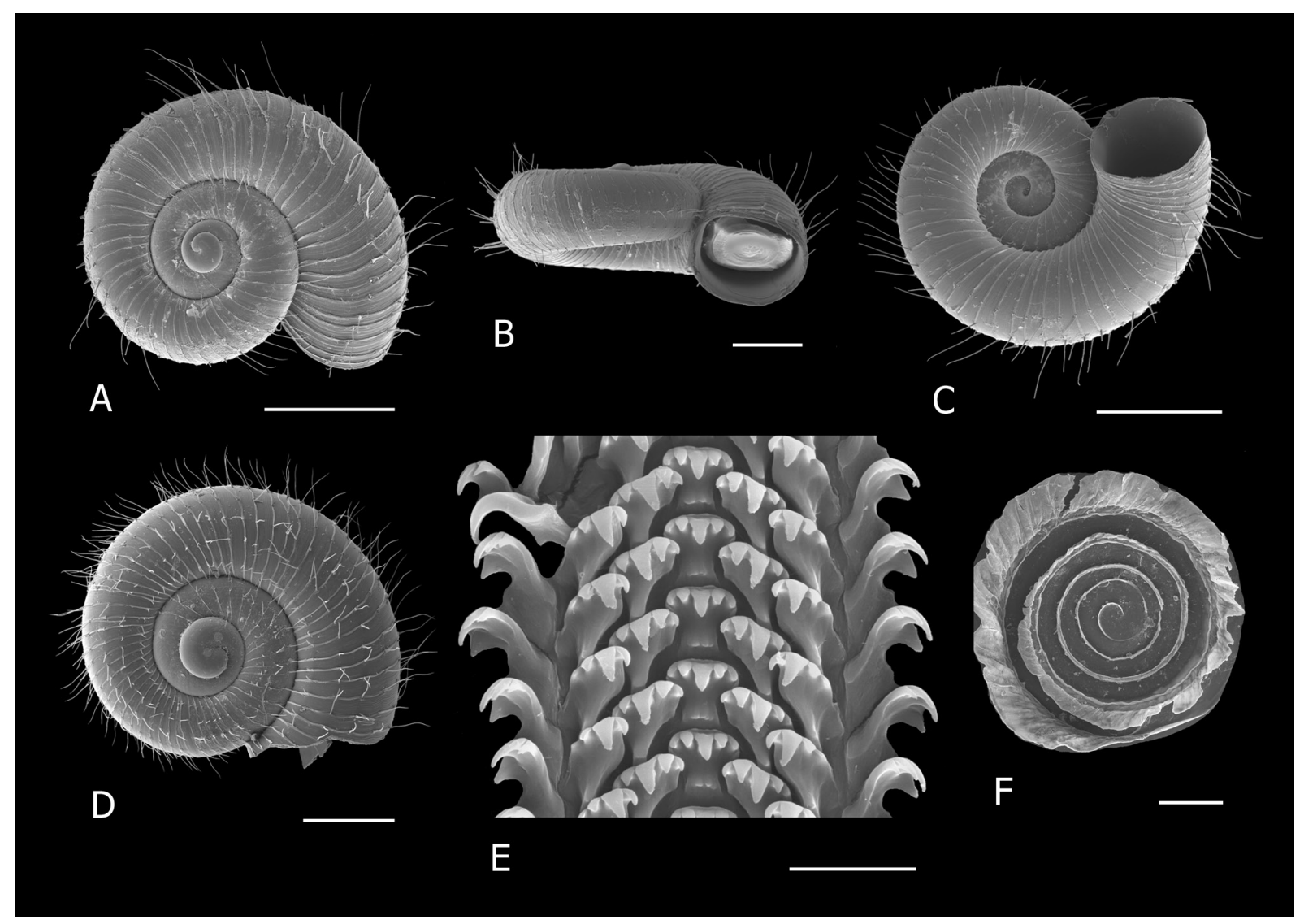

Fig. 32. Afrocyclus bhaca gen. et sp. nov. A. Dorsal view (NMSA V8277). B. Aperture view (NMSA V2075). C. Ventral view (NMSA V2075). D. Juvenile to show detail of axial lamellae of periostracum (ELM D17893). E. Portion of radula (ELM W3856). F. Operculum (NMSA V2075). Scale bars: A, C = $1 \mathrm{~mm} ; \mathrm{B}, \mathrm{D}=500 \mu \mathrm{m} ; \mathrm{E}=20 \mu \mathrm{m} ; \mathrm{F}=200 \mu \mathrm{m}$. 
RADULA (Fig. 32F). Rachidian with five cusps set a little distance below upper edge of tooth, upper edge mildly serrated, central cusp very long; first lateral tooth with four cusps and a vestigial fifth, third cusp (from centre) very long; second lateral tooth with two large cusps, second cusp (from centre) larger, a third small cusp and a vestigial fourth.

PENIS. Not examined.

\section{Distribution and habitat}

Medium altitude forests of the 'first escarpment' in the interior of north-eastern Eastern Cape and southern KwaZulu-Natal (Fig. 29).

Eastern Mistbelt and Transkei Mistbelt Forests (von Maltitz et al. 2003).

\section{Remarks}

Afrocyclus bhaca gen. et sp. nov. differed from Afrocyclus isipingoensis gen. et comb. nov. by lacking the spiral row of extremely short hairs immediately below the suture and the protoconch was more strongly sculptured, but less so than that of $A$. potteri gen. et sp. nov. and $A$. oxygala gen. et sp. nov. The protoconch was smaller than that of $A$. potteri gen. et sp. nov. (Fig. 28C-D). The two populations examined differed in the arrangement of the spiral rows of hairs: specimens from Ngele had four-five rows concentrated around the periphery (Fig. 32A-B), while specimens from near Mount Frere/Buffalo Nek had 14-15 rows on the last whorl, more or less evenly distributed over the whorl (Fig. 32D). The latter were relatively more depressed than other populations (Table 5). Specimens from Mount Frere are tentatively included in $A$. bhaca gen. et sp. nov., but may prove to be a separate species upon further study. In the molecular phylogeny they were more closely related to specimens from Ngele than to any other specimens in the Afrocyclus isipingoensis gen. et comb. nov. species complex (Fig. 1), although relatively divergent compared to the genetic variation within the majority of species (see Cole et al. 2019).

Ngele and nearby forests appear to be a hot-spot of narrow range endemism in low-vagility, saproxylic invertebrates including other molluscan taxa (e.g., Gulella claustralis Connolly, 1939) and Onychophora (Daniels et al. 2016). The occurrence of two distinct lineages (A. potteri gen. et sp. nov. and A. bhaca gen. et sp. nov.) in close proximity has also been demonstrated in this region in Onychophora, which belong to ancient lineages that diverged in the Eocene or earlier (Daniels et al. 2016). This is in contrast to findings in other molluscan taxa where populations across the region are considered to belong to the same lineage (Herbert 2017).

Afrocyclus exsertus (Melvill \& Ponsonby, 1903) gen. et comb. nov.

Figs 29,33

Chondrocyclus exsertus Melvill \& Ponsonby, 1903: 608, pl. xxxii, fig. 11 (type loc.: Umkomaas).

Chondrocyclus exsertus - Connolly 1939: 540. — Herbert \& Kilburn 2004: 92.

\section{Diagnosis}

Shell very small, moderately depressed; periostracum with dense axial costae increasing slightly in height at periphery but not expanded into spines or flanges; operculum duplex, almost flat, multispiral lamellar blade low, loose fringe of bunches of bristles, fringe of each whorl with free ends not fused to lamella of following whorl; umbilicus deep and widely open exposing all the whorls; radula with two large cusps on second lateral tooth. 


\section{Etymology}

The specific name is derived from the Latin 'exsertus', meaning 'stretched or thrust out', and referring to the elevated spire.

\section{Type material examined}

\section{Holotype}

SOUTH AFRICA - KwaZulu-Natal • Umkomaas; J.H. Ponsonby Esq. leg.; NHMUK 1904.4.29.28. (Fig. 33A)

\section{Other material examined}

SOUTH AFRICA - KwaZulu-Natal • 5 specimens; Kelso junction; NMSA A8011 4 specimens; same collection data as for preceding; ex Transvaal Museum; NMSA W465 20 specimens; Umzumbe, Trust Farm, $4.3 \mathrm{~km}$ inland of Umzumbe as crow flies, small patch of indigenous forest among sugar cane; $30.6100^{\circ} \mathrm{S}, 30.5070^{\circ}$ E; 9 Jan. 2012; M. Cole, D. Herbert, L. Davis and D. Kinsler leg.; ELM D16953 • 2 specimens; same collection data as for preceding; ELM W03655 - 2 specimens in ethanol; same collection data as for preceding; NHMUK 20120275 • 4 specimens; Frome Farm, Sunwich Port, 3.8 km inland from coast; $30.6498^{\circ} \mathrm{S}, 30.4786^{\circ} \mathrm{E} ; 100 \mathrm{~m}$ a.s.1.; 14 Apr. 2011; M. Cole, D. Herbert, L. Davis and R. Daniels leg.; ELM D16951 - 15 specimens; same collection data as for preceding; 8 Jan. 2012; M. Cole, K. Cole and D. Kinsler leg.; ELM D16952 - 3 specimens; same collection data as for preceding; ELM W3654 • 11 specimens; same collection data as for preceding; 21 Jan. 2012; D. Kinsler leg.; ELM D17010 • 2 specimens; same collection data as for preceding; NMW.Z.2012.065.00006 • 12 specimens; same collection data as for preceding; 4 Feb. 2015; D. Kinsler leg.; ELM D17935 • 5 specimens; Umzumbe, Clouds Hill; 30.6275 ${ }^{\circ}$ S, 30.5308 ${ }^{\circ}$ E; 21 m a.s.l.; 13 Feb. 2012; D. Kinsler leg.; ELM D17011 • 15 specimens; same collection data as for preceding; 4 Feb. 2015; D. Kinsler leg.; ELM D17936.

\section{Description}

SHELl (Fig. 33A-C). Very small, adult diameter 2.96-4.64 mm, height 1.82-2.86 mm, diameter:height 1.39-1.86 ( $\mathrm{n}=25)$ (Fig. 33A-B, E-F). Spire moderately exserted, protoconch not mammillate (Fig. 33B). Embryonic shell (Fig. 33C) just over 2.5 whorls, microscopically malleate, roughest in centre; junction between embryonic shell and teleoconch evident with development of costae on teleoconch. Teleoconch comprising just under two whorls, very convex, rapidly increasing, suture impressed. Aperture circular, last whorl descending near aperture, peristome simple, continuous and free. Umbilicus wide and deep, exposing all the whorls (Fig. 33F). Periostracum pale yellowish-brown with lamellate axial costae at regular intervals, $84-110(\mathrm{n}=14)$ on last whorl, each lamellar blade has numerous tiny vertical ridges visible at very high magnification (Fig. 33D); lamellar blades increase in height at periphery but not expanded into flanges or hairs; intervals between costae with microscopic axial threads. Shell translucent and corneous when fresh.

OperCulum (Fig. 33H, J). Duplex, almost flat, multispiral outer portion with a broad, thin nucleus and six whorls, height of lamellar blade low and not stepped, thickened horizontal ridge near bottom of blade just above disc surface, loose fringe of bristles emanates from ridge, fringe consists of bunches of short bristles, with free ends not fused to lamella of following whorl, fringe of outer whorl overlaps disc slightly.

RADULA (Fig. 33G). Rachidian with five cusps, central cusp approx. twice length of outer cusps, outermost cusps relatively weak, cusps of rachidian set a little distance below 'top' of tooth, top edge serrated; first lateral tooth usually with three large cusps, third cusp (from centre) largest, a small fourth cusp and a 


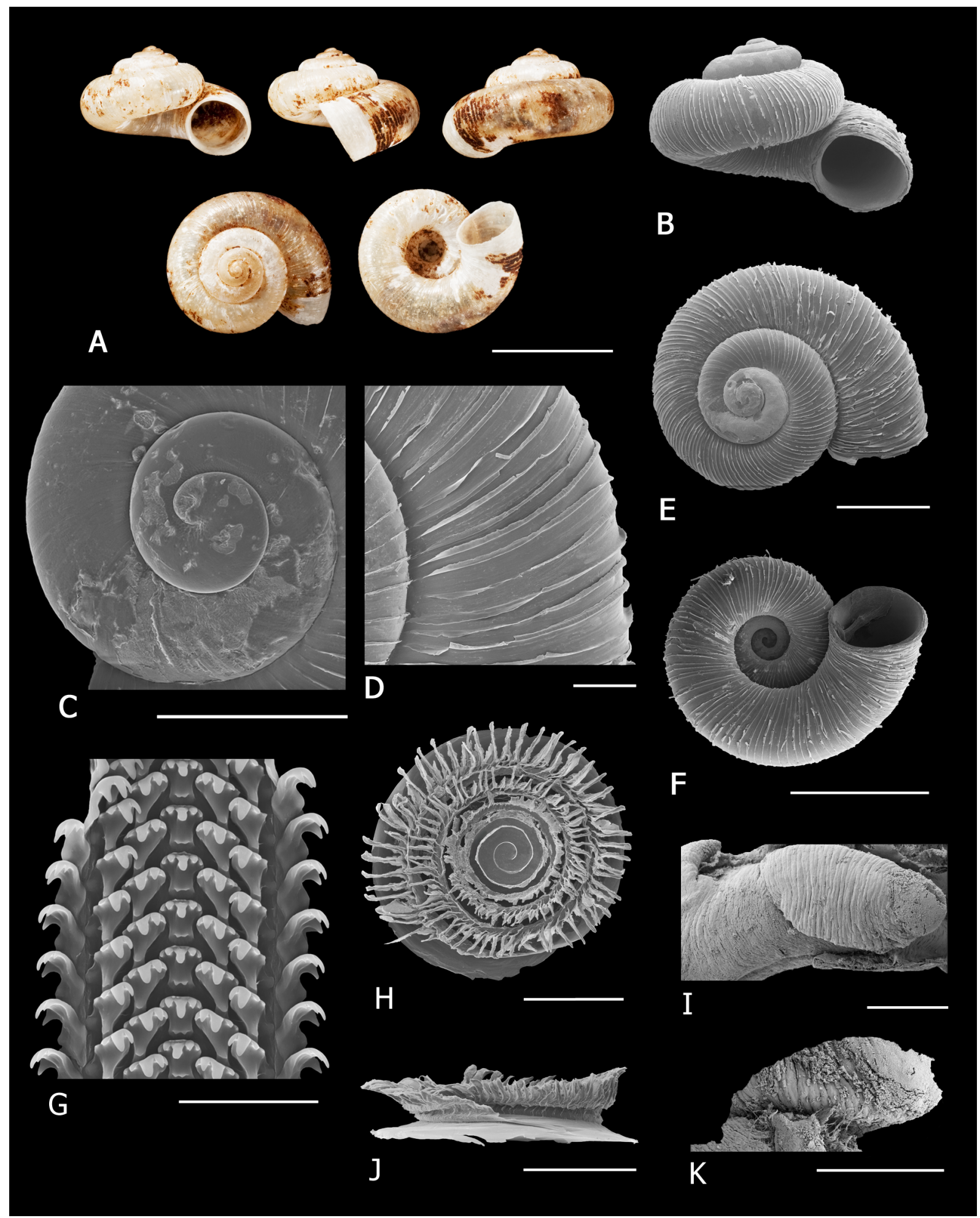

Fig. 33. Afrocyclus exsertus (Melvill \& Ponsonby, 1903) gen. et comb. nov. A. Holotype (NHMUK 1904.4.29.28). B. Aperture view (ELM D16953). C. Protoconch (ELM D16951). D. Detail of axial lamellae of periostracum (ELM D16951). E. Dorsal view (ELM D16951). F. Ventral view (ELM W3654). G. Portion of radula (ELM W3654). H. Operculum (ELM W3654). I. Penis, dorsal view (ELM W3654). J. Operculum, lateral view (ELM W3655). K. Penis, lateral view (ELM W3654). Scale bars: $\mathrm{A}=3 \mathrm{~mm} ; \mathrm{B}, \mathrm{E}=1 \mathrm{~mm} ; \mathrm{C}, \mathrm{H}-\mathrm{K}=500 \mu \mathrm{m} ; \mathrm{D}=200 \mu \mathrm{m} ; \mathrm{F}=2 \mathrm{~mm} ; \mathrm{G}=50 \mu \mathrm{m}$. 
vestigial fifth; second lateral tooth with two large cusps, second cusp (from centre) longer and broader than first, a very small third cusp and a vestigial fourth.

PenIs (Fig. 33I, K). Shaft short, broad and more or less cylindrical, intromittent organ very short.

\section{Distribution and habitat}

Endemic to the coastal belt of southern Kwazulu-Natal and possibly extending into northern Pondoland. Recent specimens found in a few small patches of remaining indigenous forest inland of Umtentwini and Umzumbe (Fig. 29).

Indigenous Scarp Forest (Mucina \& Geldenhuys 2006), on steep, rocky slopes, in leaf litter.

\section{Remarks}

The spire is more elevated than in the majority of other species of Afrocyclus and in the majority of species of Chondrocyclus s.s. barring $C$. herberti sp. nov., with similar shell proportions to the latter. The periostracum has simpler axial lamellae than other species, lacking flanges or hairs. The operculum is unique in that the fringe consists of bunches of bristles with free ends which are not fused to the lamellar blade of the following whorl; fringe has a looser arrangement with fewer bristles than in all other species. The radula resembles that of $A$. isipingoensis gen. et comb. nov., including the unusual serrated top edge of the rachidian.

Afrocyclus exsertus gen. et comb. nov. is very rare and patchily distributed. Despite searching, it has not been found recently at any of the localities recorded by Connolly (1939) or in several other patches of forest on the Kwazulu-Natal south coast, excepting three very small patches among sugarcane fields, where it was presumably too steep for clearing of original forest. The vegetation on the Kwazulu-Natal south coast has undergone extensive modification since 1939.

\section{Cyathopoma meredithae (Bruggen, 1983) comb. nov. and Cyathopoma chirindae (Bruggen, 1986) comb. nov.}

Cyathopoma meredithae comb. nov. and Cyathopoma chirindae comb. nov. are removed from genus Chondrocyclus s.l. for three reasons, based on morphology of shell and operculum: i) shells have spiral keels while those of Chondrocyclus s.l. are smooth once the periostracum is removed, ii) opercula are calcareous, while those of Chondrocyclus s.l. are corneous, iii) periostracum is not glossy and lacquerlike as in all Chondrocyclus s.l. species, but is white and matt, suggesting a degree of calcification. C. meredithae (Bruggen, 1983) comb. nov. and C. chirindae (Bruggen, 1986) comb. nov. resemble one another in general shape, possession of periostracal hairs at junctions between axial and spiral sculpture, and in the appearance of the operculum, but the latter has more dense axial lamellae and spiral keels (Fig. 34).

Bruggen (1986) erroneously considered major spiral sculpture in the form of keels, ridges or cords to be a diagnostic feature of the Cyclophoridae in Africa. Shells of species of Chondrocyclus s.l. have spiral rows of periostracal projections, but are usually smooth once the periostracum is removed with only traces of axial sculpture. (Chondrocyclus kevincolei sp. nov. and to a lesser extent $C$. langebergensis sp. nov. from the Western Cape have spiral engraving.) Cyathopoma meredithae comb. nov. and C. chirindae comb. nov. both have a reticulate surface sculpture with spiral keels and axial lamellae more or less equal in density, with dark brown bristles on the points where the axial and spiral sculpture meet. In both species the periostracum is described as "corneous" (Bruggen 1983, 1986). However, the periostracum of C. chirindae (NM L4904) (Fig. 33B) does not appear to be "corneous", but is white and 
matt, suggesting a degree of calcification and this is also apparent to a lesser degree in C. meredithae comb. nov.

The descriptions of their opercula are also identical: duplex with exterior portion in the form of a large, concave, shallow saucer with six-eight spiral whorls (Bruggen 1983, 1986). Bruggen does not mention whether the opercula are corneous or calcareous. Examination of the operculum of $C$. chirindae comb. nov. (NM L4904) and the photograph of the operculum of C. meredithae comb. nov. (Fig. 34A) shows that both species have a calcareous operculum.

Attempts to assign the abovementioned two species to other genera are complicated by the fact that all other genera of operculate snails in mainland Africa and Madagascar are in need of revision (Emberton 2009). Until recently, three of the African cyclophorids were placed in Afroditropis Bequaert \& Clench, 1936, a genus characterised by widely spaced spiral keels on the shell, a thin peristome, not reflexed nor flaring, and a thin, corneous, simple operculum. Afroditropis was synonymised with Cyathopoma by de Winter (2002), based on conchological similarity as well as similarities between the opercula of two specimens identified as A. strongi Bequaert \& Clench, 1936, and the opercular structure of Cyathopoma africanum Pilsbry, 1919, C. straeleni Adam, 1987 and C. camerunense de Winter, 2002.

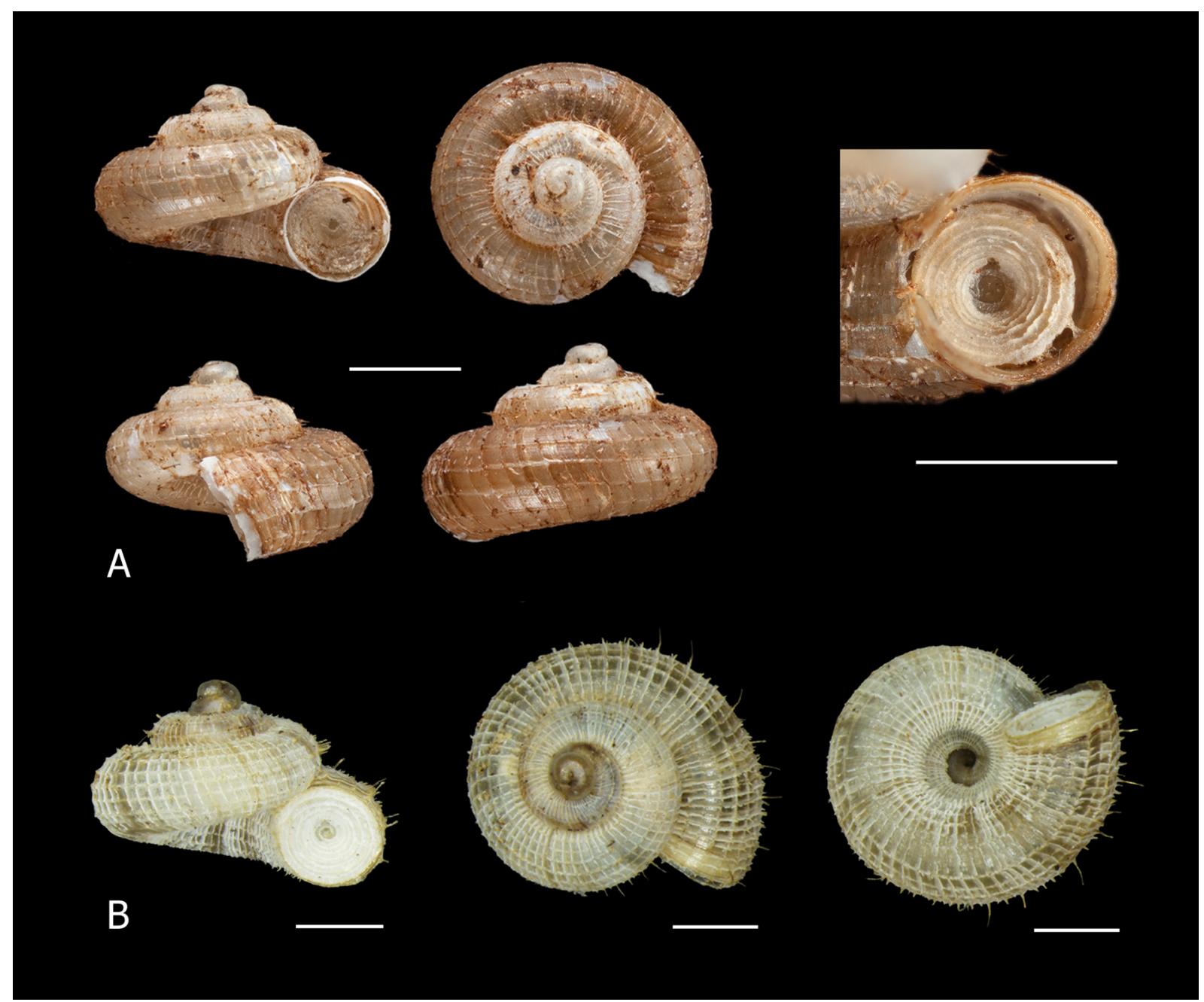

Fig. 34. A. Cyathopoma meredithae (Bruggen, 1983) comb. nov., paratype and close-up of operculum (NHMUK 198338). B. Cyathopoma chirindae (Bruggen, 1986) comb. nov. (NMSA L4904). Scale bars: $\mathrm{A}-\mathrm{B}=1 \mathrm{~mm}$. 
Whether these genera should be synonymised remains inconclusive since de Winter (2002) did not examine the operculum of the type specimen of $A$. strongi and he acknowledged that the two specimens on which he based his synonymy may actually represent an as yet undescribed species due to various differences between each of them and A. strongi. The other mainland African genus in Cyclophoridae is Elgonocyclus Verdcourt, 1982 with two species, E. koptawaliensis (Germain, 1934) and an undescribed species from Ongoye forest, Zululand, both minute species with marked axial costulation and simple, corneous opercula.

Recently described African cyclophorids have been placed in Cyathopoma (e.g., C. camerunense de Winter, 2002; C. tres Bruggen, 2008 and C. pembense Rowson, 2010 in Rowson et al. 2010b) and following this trend, Cyathopoma meredithae comb. nov. and C. chirindae comb. nov. were tentatively placed in Cyathopoma (Cole et al. 2019). The diagnosis in Blanford (1864) of Cyathopoma relies chiefly on features of the operculum which is usually truncate-conoid, with the concave exterior portion formed by a calcareous, spiral lamella which usually curves inwards towards the centre and is sometimes beautifully sculpted and elevated. The only cyclophorid on mainland Africa with an operculum conforming to this pattern is Cyathopoma tres Bruggen, 2008, from Malawi, whereas in all the other mainland African species, including Cyathopoma meredithae comb. nov. and C. chirindae comb. nov., the operculum is concave since the erect spiral lamella is higher towards the periphery (Figs 34, 35A, C). There is considerable variation in the opercula of the 60 Malagasy species currently assigned to Cyathopoma s.l. so a future revision may lead to amendment of Blanford's diagnosis (Emberton 2003). At the time of the descriptions of Cyathopoma meredithae comb. nov. and C. chirindae comb. nov. the opercula of African Cyathopoma (except C. africanum Pilsbry, 1919) were not known because many of the current species had not yet been described (e.g., Cyathopoma straeleni Adam, 1987, C. camerunense de Winter, 2002, C. pembense Rowson, 2010) or the operculum was not known (C. azaniense Verdcourt, 1978). The opercula of both Chondrocyclus s.l. and Cyathopoma are duplex, with an erect spiral lamella forming the whorls of the exterior portion, but that of Chondrocyclus s.l. is uncalcified (Kobelt 1902) while that of Cyathopoma is calcareous (Blanford 1864).

The reticulate surface sculpture of Cyathopoma meredithae comb. nov. and C. chirindae comb. nov. is unlike that of all other mainland African Cyathopoma which have prominent spiral keels and numerous closely set axial riblets. As far as is known, no other mainland African cyclophorids (except Chondrocyclus s.1.) have periostracal bristles. In some species the axial striae grow out into long processes of the periostracum, adhering in groups to the keels, e.g., Cyathopoma africanum Pilsbry, 1919 and C. pembense Rowson, 2010. It is not known whether such an elaborate periostracum occurs in the other African species because it is easily worn off. The type species of Cyathopoma, C. filocinctum Benson, 1851, as well as a few Malagasy species (Emberton 2003), also have reticulate surface sculpture, and a few Malagasy species have periostracal hairs (Emberton 2003).

The reticulate appearance of Cyathopoma meredithae comb. nov. and $C$ chirindae comb. nov. resembles several species of Malagasy Cyclotus (Emberton 2004) (Fig. 36A-B). In some Malagasy Cyclotus the axial lamellate costae elevate into triangular periostracal projections along the sutural edge and within the umbilicus (Emberton 2004). In C. chirindae comb. nov. the sharp edged lamellae are raised into small triangular projections at the junctions with the spiral keels and these are particularly dense within the umbilicus (Fig. 34B). The operculum of the specimen of Cyclotus examined is flat and bilayered (Fig. 36C-D), and resembles that of the type species of Cyclotus, C. variegatus Swainson, 1840 (Fig. 36E), the outer surface concave, formed by an inwardly curving, spiral calcareous sheet that increases in elevation towards the periphery and without projections or appendages. Bruggen (1983) draws attention to the similarity between the opercula of C. meredithae comb. nov. and Cyclotus mamillaris Odhner, 1919 (which at the time of Bruggen's description was classified as Chondrocyclus mamillaris (Fischer-Piette et al. 1993)). 
Cyathopoma meredithae comb. nov. and $C$ chirindae comb. nov. both have a thin peristome, practically free, but with a limited area touching the body whorl (Fig. 34), but it is not certain whether the specimens examined were adult. In adult Chondrocyclus s.l. the peristome is detached from the last whorl and droops downwards, but in subadults it is attached in a limited area. The peristome of $C$. filocinctum Benson, 1851 is moderately thick with a broad basal flare, and in several mainland African and Malagasy Cyathopoma it is expanded and may also be thickened.

The radulae and penes of mainland African and Malagasy Cyathopoma and Cyclotus have not been documented prior to this study and no bodies of Cyathopoma meredithae comb. nov. or C. chirindae comb. nov. were available for examination. These features have proved useful in diagnosis and taxonomy of species of Chondrocyclus s.1., so their examination in C. meredithae comb. nov. and C. chirindae comb. nov. may provide useful insights as to their affinities, even though they would probably not assist with generic placement at present. The penis of Cyathopoma pembense is extremely long and narrow relative to that of Chondrocyclus s.l. and does not appear to have an intromittent organ, but tapers to a very fine point (Fig. 35D). The penis of Cyclotus sp. from Madagascar resembles that of C. pembense, but has a relatively broader shaft which also narrows to a fine point and no intromittent organ (Fig. 36G-

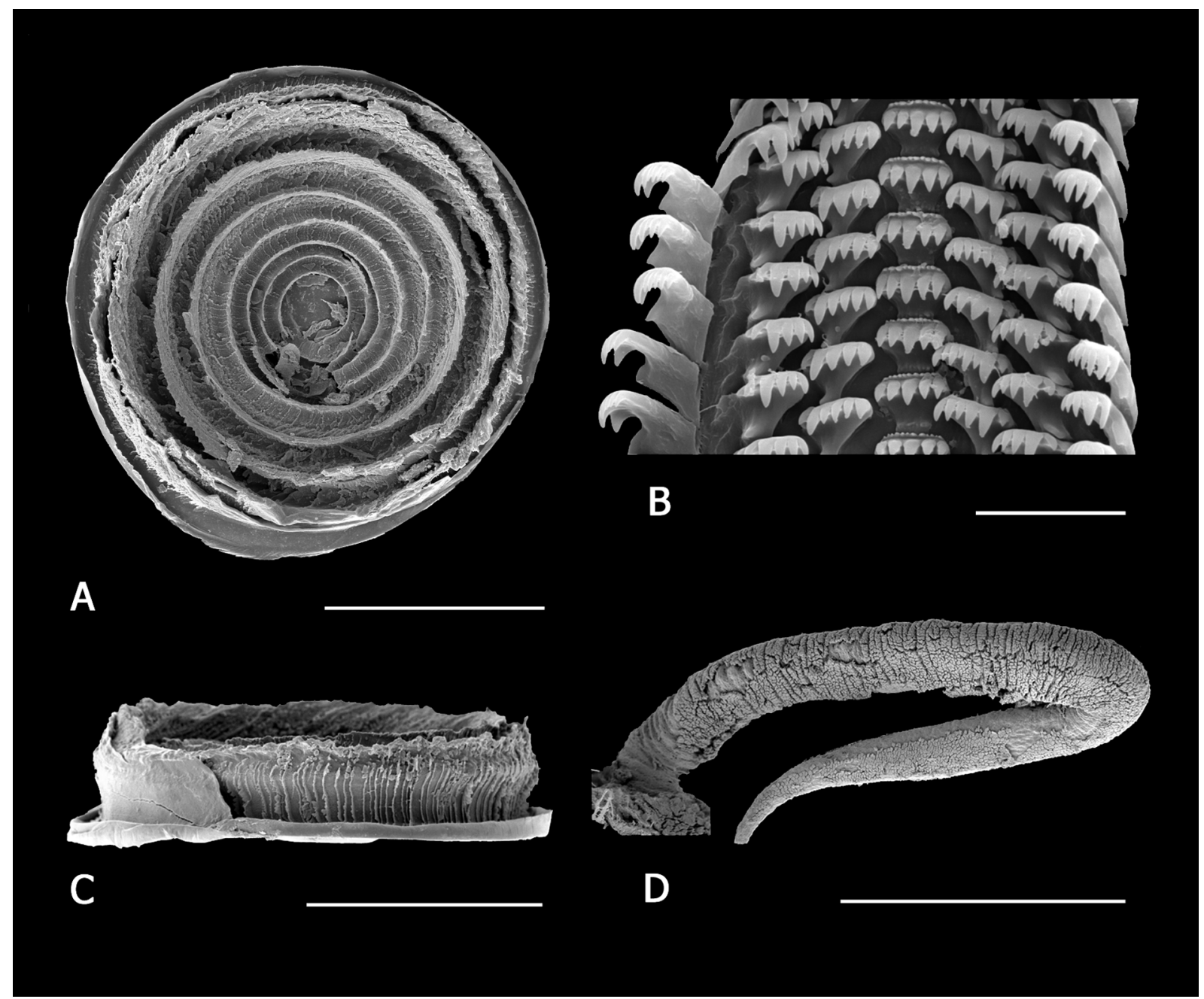

Fig. 35. Cyathopoma pembense Rowson, 2010. A-D. ELM D18464. A, C. Operculum. B. Portion of radula. D. Penis, lateral view. Scale bars: A, C-D $=500 \mu \mathrm{m} ; \mathrm{B}=20 \mu \mathrm{m}$. 
H). What appears to be a groove possibly corresponding to a seminal groove, runs down the ventral surface. In both these species the penis lies doubled back on itself.

The radulae of Cyathopoma pembense and Cyclotus sp. differ (Figs 35B and 36F). Cyathopoma pembense has a serrated upper edge to the rachidian tooth, also found in Afrocyclus gen. nov., but the first and second lateral teeth have four large cusps (often with extras), unlike the radula of any Afrocyclus gen. nov. or species of Chondrocyclus s.s. The radula of Cyclotus sp. resembles the radulae of

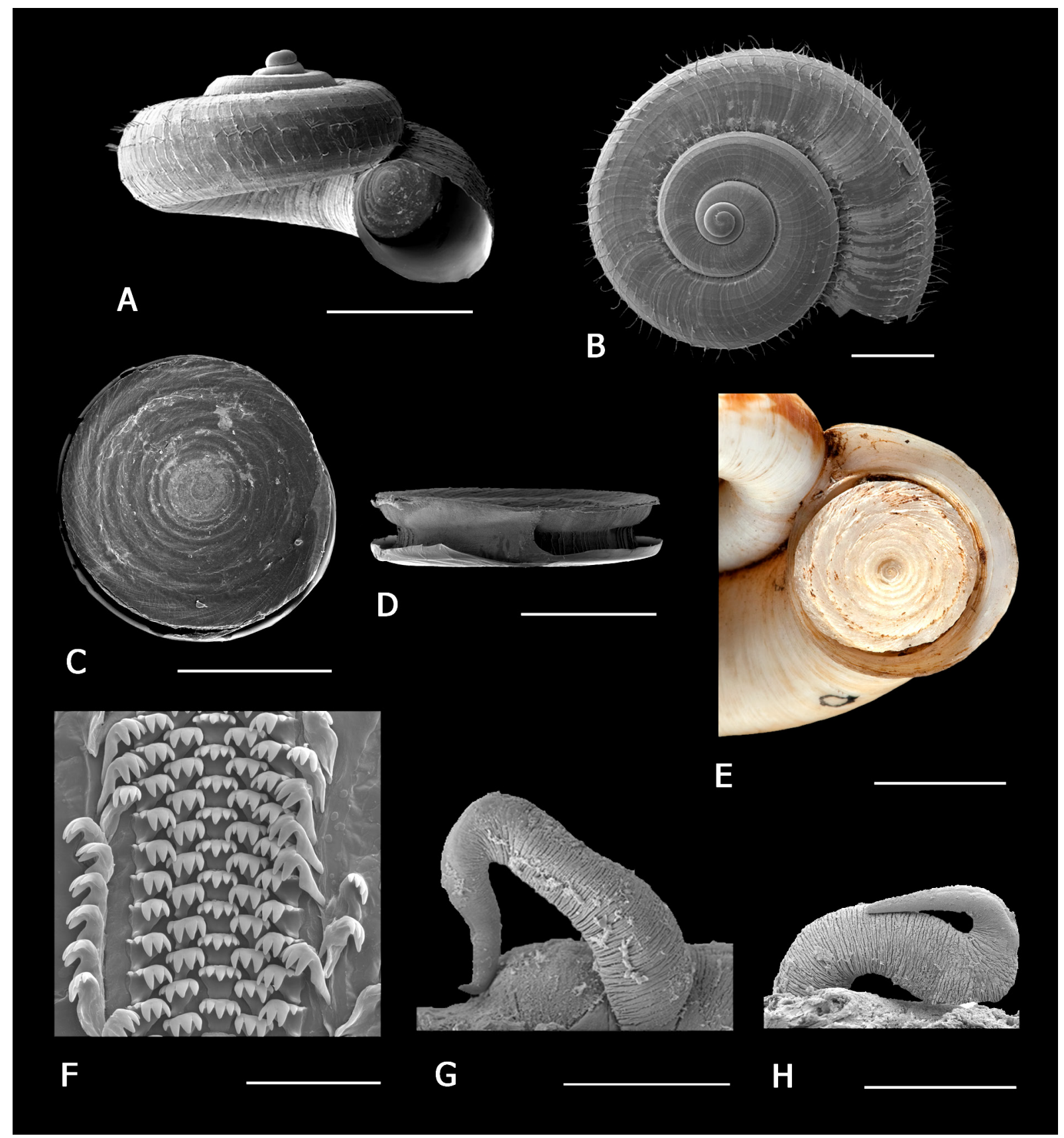

Fig. 36. Cyclotus sp. A. Aperture view (NMSA L7108). B. Dorsal view (NMSA L7108). C-D. Operculum (NMSA L7108). E. Cyclotus variegatus Swainson, 1840 operculum (NHMUK1893.6.7.43-5). F. Portion of radula (NMSA L7108). G. Penis, dorsal view (NMSA L7108). H. Penis lateral view (NMSA L7108). Scale bars: A-B $=2 \mathrm{~mm} ; \mathrm{C}, \mathrm{E}=1 \mathrm{~mm} ; \mathrm{D}, \mathrm{G}-\mathrm{H}=500 \mu \mathrm{m} ; \mathrm{F}=50 \mu \mathrm{m}$. 
COLE M.L., Revision of cyclophorid snails Chondrocyclus s.l.

several species of Chondrocyclus s.s., with three large cusps on the second lateral tooth. As noted in the Comparative morphological observations section, radulae of various Cyclophoridae look superficially alike, so similarities in the radula do not necessarily imply close relationship.

\section{Discussion}

This study is a significant contribution to the knowledge of molluscs on the African continent and in South Africa in particular. Although considerable progress has been made in taxonomy and systematics of South African terrestrial molluscs in the past few decades, the majority of South African taxa still require revision and a host of species await description. Studies which have been undertaken consist of species descriptions across a small range of taxa (Bruggen 1965, 1966, 2006; Herbert 2002, 2006, 2016; Bursey \& Herbert 2004; Cole \& Herbert 2009), a few revisions (Herbert 2007; Herbert \& Moussalli 2010, 2016) and a limited number of other treatments (Sirgel 1985; Herbert 1997, 2006, 2017; Herbert \& Kilburn 2004). In total, only a handful of molecular studies have been undertaken on African land snails (Herbert \& Mitchell 2009; Moussalli \& Herbert 2016; Rowson \& Herbert 2016; Moussalli et al. 2009; Cole et al. 2019) and very few global studies have included African taxa (Rowson et al. 2010a; Fontanilla et al. 2017; Harl et al. 2017).

Chondrocyclus s.s. and, as far as is known, Afrocyclus gen. nov. are endemic to South Africa and the majority of species are narrow-range endemics. This study reveals a large proportion of undetected diversity in the family, both as cryptic species previously included under other names (i.e., overlooked because identifications were based on old/worn shell material) or as new discoveries. With a better understanding of the family's species composition and distribution, an assessments of species qualifying for Red Listing can now be made. Forests cover only $0.1 \%$ of South Africa's land surface and are highly fragmented (Mucina \& Geldenhuys 2006). Forest degradation and further fragmentation through human activity are threatening the survival of the biome and leading to changes in species abundance and distribution (Eeley et al. 1999; Cooper et al. 2017). These habitats have been shown to contain high levels of undetected diversity and endemism in molluscs (Herbert 2016, 2017; Bursey \& Herbert 2004; Cole \& Herbert 2009; Herbert \& Moussalli 2010, 2016) and other low-vagility invertebrate taxa (Huber 2003; Hamer \& Slotow 2002; Tilbury \& Tolley 2009; de Bivort \& Giribet 2010; Ruhberg \& Daniels 2013; Daniels et al. 2009, 2013, 2016; McDonald et al. 2012). The contractions and expansions of forest habitat due to climatic oscillations (Mucina \& Geldenhuys 2006; Scott et al. 1997; Partridge et al. 1999) appear to have resulted in the formation of complex phylogeographic patterning, potentially promoting cladogenesis among forest-dwelling habitat specialists (McDonald \& Daniels 2012; Daniels et al. 2016, 2017). Observations on biogeography of Chondrocyclus s.l., and parallel distribution patterns in a range of low-vagility forest-dwelling taxa, are discussed in Cole et al. (2019) but data on invertebrates remains patchy (McGeoch et al. 2011; Daniels et al. 2017). This study will complement other research by providing comparative material for an independent, widespread group and expand the scientific evidence available for biodiversity conservation in South Africa. Improved knowledge of the composition and distribution of this group of forest specialists with weak dispersal capabilities may contribute insights into the processes generating biodiversity in the region where common patterns across unrelated taxa are beginning to emerge.

This is the first detailed systematic revision of an Afrotropical cyclophorid group to include morphological and molecular data. It lays a foundation for further studies of the family elsewhere in Africa, including relationships between taxa. Molecular data and anatomical studies on the soft parts of other African cyclophoroidean taxa, including Cyathopoma meredithae comb. nov. and C. chirindae comb. nov., Elgonocyclus spp. and the mainland African endemic family Maizaniidae to supplement morphological observations of their shells and opercula would enable assessment of their affinities to Chondrocyclus s.l. 
There appears to be uncertainty as regards placement of genera in Cyclophoroidean families (Bouchet et al. 2017) and Chondrocyclus has been included in the Megalomastomatidae in one classification system (Bank 2017 unpublished, see MolluscaBase (2019) http://www.molluscabase.org/aphia.php?p=taxdetails\&id=995565; accessed on 26 Apr. 2019). This study and that of Cole et al. (2019), contribute data to assist with such decision-making. Although a global phylogeny has not been attempted, there has been increasing research interest in taxonomy of Cyclophoroidea of Asia and Australasia (e.g., Marshall \& Barker 2007; Lee et al. 2008a, 2008b; Rundell 2008; Webster et al. 2012; Yamakazi et al. 2013, 2015a, 2015b; Liew et al. 2014; Nantarat et al. 2014b; Sutcharit et al. 2014; Neubert \& Bouchet 2015; Páll-Gergely et al. 2015, 2017a, 2017b; Foon \& Liew 2017; Phung et al. 2017; von Oheimb et al. 2018) and Madagascar (Emberton 2002a, 2002b, 2003, 2004, 2009; Emberton et al. 2010), and this study provides further pieces in the puzzle of this very large group.

\section{Acknowledgements}

Kevin Cole, David Herbert, Victor Mejane, Linda Davis, Ryan Daniels, Tony Dold, D-J Hodgkinson, Mike Wigley, David Kinsler, Karl Edwards, Geoff Nichols, Alex Skene and Shaughan Cole are thanked for assistance with fieldwork, Owen Griffiths and Roger Randalana for specimens of Cyclotus and Ben Rowson for specimens of Cyathopoma pembense. Theunis Morgenthal prepared the maps. David Herbert provided constructive comments. Louanne Kirton helped prepare plates of photographs. Jon Ablett facilitated examination of types in the NHMUK collection and Harry Taylor photographed NHMUK types. Financial support was received from the National Research Foundation of South Africa (NRF) [grant number KFD2008061300004 (to MLC.); grant number 81078 (to David Herbert)]. The NRF had no involvement in the preparation of the data or manuscript. The East London Museum is acknowledged for funds towards running costs. Research permits were received from Eastern Cape Parks and Tourism Agency (RA0063 and RA0194), Ezemvelo KZN Wildlife (OP5180/2009-2015), Cape Nature (AAA00400308-0035), South African National Parks, Department of Agriculture, Fisheries and Forestry, and Buffalo City Metropolitan Municipality.

\section{References}

Ancey C.F. 1898. Observations sur les Mollusques terrestres et fluviatiles recueillies dans l'Indo-Chine et particulièrement au Laos, par M. Henri Counillon, accompagnées de remarques sur d'autres mollusques de cette région, par C.-F. Ancey. Annales du Musée d'Histoire naturelle de Marseille 1: 134-136.

Bank R. 2017. MolluscaBase-Classification of the Recent terrestrial Gastropoda of the World. Last update: July $16^{\text {th }}$, 2017. Available from http://www.molluscabase.org/aphia.php?p=taxdetails\&id=995565 [accessed on 26 Apr. 2019].

Benson W.H. 1856. New land shells collected by E. L. Layard Esq. and described by W.H. Benson, Esq. Annals and Magazine of Natural History Series 2 18: 433-439.

Blanford W.T. 1864. On the classification of the Cyclostomacea of Eastern Asia. Annals and Magazine of Natural History Series 3 13: 441-465.

Bouchet P., Rocroi J.P., Hausdorf B., Kaim A., Kano Y., Nützel A., Parkhaev P., Schrödl M. \& Strong E.E. 2017. Revised classification, nomenclator and typification of gastropod and monoplacophoran families. Malacologia 61: 1-526. Available from http://www.bioone.org/doi/pdf/10.4002/040.061.0201 [accessed 19 Sep. 2019].

Branch G. \& Branch M. 1981. The Living Shores of Southern Africa. Struik, Cape Town.

Bruggen A.C. van. 1965. Descriptions of three new species of Gulella (Mollusca, Gastropoda Pulmonata: Streptaxidae) from South Africa. Annals of the Natal Museum 18 (1): 21-26. 
COLE M.L., Revision of cyclophorid snails Chondrocyclus s.l.

Bruggen A.C. van. 1966. The terrestrial Mollusca of the Kruger National Park: a contribution to the malacology of the Eastern Transvaal. Annals of the Natal Museum 18 (2): 315-399.

Bruggen A. C. van. 1978. Land molluscs. In: Werger M.J.A. (ed.) Biogeography and Ecology of Southern Africa: 877-923. Dr. W. Junk, The Hague.

Bruggen A.C. van. 1983. On some terrestrial operculates (Mollusca, Gastropoda Prosobranchia) from Malawi with the description of two new species. Proceedings of the Koninklijke Nederlandse Akademie van Wetenschappen 86 (1): 1-14.

Bruggen A.C. van. 1985. Neomazania coryli, a new genus and species of Maizaniidae (Mollusca, Gastropoda Prosobranchia) from Malawi, south central Africa. Proceedings of the Koninklijke Nederlandse Akademie van Wetenschappen 88 (4): 395-403.

Bruggen A.C. van. 1986. Further notes on Afrotropical prosobranch land molluses (Gastropoda Prosobranchia: Maizaniidae, Cyclophoridae). Proceedings of the Koninklijke Nederlandse Akademie van Wetenschappen 89 (4): 357-378.

Bruggen A.C. van. 2006. Gulella johannae spec. nov. (Gastropoda, Pulmonata, Streptaxidae), a new land snail from the Drakensberg range in Limpopo Province, South Africa, with notes on G. johannesburgensis (M. \& P.). Zoologische Mededelingen 80: 63-72.

Bursey M.L. \& Herbert D.G. 2004. Four new narrow-range endemic species of Gulella from Eastern Cape, South Africa (Mollusca: Pulmonata: Streptaxidae). African Invertebrates 45: 249-262.

Clark V.R., Barker N.P., McMaster C. \& Mucina L. 2010. The Boschberg (Somerset East, Eastern Cape) - a floristic cross-roads of the southern Great Escarpment. South African Journal of Botany 77 (1): 94-104. https://doi.org/10.1016/j.sajb.2010.06.005

Cole M.L. \& Herbert D.G. 2009. Description of four new species of Gulella Pfeiffer, 1856 from Eastern Cape, South Africa, with additional notes on two poorly known species (Mollusca: Eupulmonata: Streptaxidae). Zoologische Mededelingen 83: 547-564.

Cole M.L., Raheem D.C. \& Villet M.H. 2019. Molecular phylogeny of Chondrocyclus (Gastropoda: Cyclophoridae), a widespread genus of sedentary, restricted-range snails. Molecular Phylogenetics and Evolution 131: 193-210. https://doi.org/10.1016/j.ympev.2018.09.018

Connolly M. 1929. New non-marine mollusca from South Africa. Annals of the Natal Museum 6: 238.

Connolly M. 1939. A monographic survey of South African non-marine Mollusca. Annals of the South African Museum 33: 1-660.

Cooper T.J.G., Wannenburgh A.M. \& Cherry M.I. 2017. Atlas data indicate forest dependent bird species declines in South Africa. Bird Conservation International 27: 337-354.

https://doi.org/10.1017/S095927091600040X

Cowling R. \& Pierce S. 2009. East of the Cape: Conserving Eden. Fernwood Press, Simon's Town.

Cowling R.M., Procheş Ş. \& Partridge T.C. 2008. Explaining the uniqueness of the Cape flora: incorporating geomorphic evolution as a factor for explaining its diversification. Molecular Phylogenetics and Evolution 51 (1): 64-74. https://doi.org/10.1016/j.ympev.2008.05.034

Craven A.E. 1880. Description of three new species of land-shells from Cape Colony and Natal. Proceedings of the Zoological Society 1880: 618-619.

Daniels S.R. \& Ruhberg H. 2010. Molecular and morphological variation in a South African velvet worm (Peripatopsis moseleyi) (Onychophora, Peripatopsidae): evidence of cryptic speciation. Journal of Zoology 282: 171-179. https://doi.org/10.1111/j.1469-7998.2010.00722.x 
Daniels S.R., Picker M.D., Cowlin R.M. \& Hamer M.L. 2009. Unravelling evolutionary lineages among South African velvet worms (Onychophora: Peripatopsis) provides evidence for widespread cryptic speciation. Biological Journal of the Linnean Society 97 (1): 200-216.

https://doi.org/10.1111/j.1095-8312.2009.01205.x

Daniels S.R., McDonald D.E. \& Picker M.D. 2013. Evolutionary insight into the Peripatopsis balfouri sensu lato species complex (Onychophora: Peripatopsidae) reveals novel lineages and zoogeographic patterning. Zoologica Scripta 42 (6): 656-674. https://doi.org/10.1111/zsc.12025

Daniels S.R., Dambire C., Klaus S. \& Sharma P.P. 2016. Unmasking alpha diversity, cladogenesis and biogeographical patterning in an ancient panarthropod lineage (Onychophora: Peripatopsidae: Opisthopatus cinctipes) with the description of five novel species. Cladistics 2016: 1-32.

https://doi.org/10.1111/cla.12154

Daniels S.R, Dreyer M. \& Sharma P. 2017. Contrasting the populations genetic structure of two velvet worm taxa (Onychophora: Peripatopsidae: Peripatopsis) in forest fragments along the south-eastern Cape, South Africa. Invertebrate Systematics 31: 781-796. https://doi.org/10.1071/IS16085

De Bivort B.L. \& Giribet G. 2010. A systematic revision of the South African Pettalidae (Arachnida: Opiliones: Cyphophthalmi) based on a combined analysis of discrete and continuous morphological characters with the description of seven new species. Invertebrate Systematics 24: 371-406.

https://doi.org/10.1071/IS10015

De Winter A.J. 2002. Notes on land operculates from Cameroon (Gastropoda: Cyclophoridae and Maizaniidae), including the description of two new species. In: Faulkner M., Groh K. \& Speight M.C.D. (eds) Collecteana Malacologia Festschrift für Gerhard Falkner: 237-251. ConchBooks, Hackenheim.

Eeley H.A.C., Lawes M.J. \& Piper S.E. 1999. The influence of climate change on the distribution of indigenous forest in Kwazulu-Natal, South Africa. Journal of Biogeography 26: 595-617.

Emberton K.C. 2002a. Ankoravaratra, a new genus of land snails endemic to northern Madagascar (Cyclophoroidea: Maizaniidae?). The Veliger 45 (4): 278-289.

Emberton K.C. 2002b. The genus Boucardicus, a Madagascan endemic. Archiv für Molluskenkunde 130 (1-2): 1-199.

Emberton K.C. 2003. Madagascan Cyathopoma sensu lato. Archiv für Molluskenkunde 132: 9-91.

Emberton K.C. 2004. Madagascan Georissa, Cyclotus, Omphalotropis and so-called Chondrocyclus (Gastropoda: Caenogastropoda: Hydrocenidae, Cyclophoridae, Assimineidae). Archiv für Molluskenkunde 133 (1-2): 69-107.

Emberton K.C. 2009. Operculate land snails from three rainforest transects in northeastern Madagascar, with description of nine new species and one new subspecies. Archiv für Molluskenkunde 138: 1-41. https://doi.org/10.1127/arch.moll/0003-9284/138/001-041

Emberton K.C. \& Pearce T.A. 1999. Land caenogastropods of Mounts Mahermana, Ilapiry, and Vasiha, southeastern Madagascar, with conservation statuses of 17 species of Boucardicus. The Veliger 42 (4): $338-372$.

Emberton K.C., Slapcinsky J., Campbell C.A., Rakotondrazafy J.A., Andriamiarison T.N. \& Emberton J.D. 2010. Terrestrial mollusks of Andriantantely Massif, Eastern Madagascar, with descriptions of 36 new species (Gastropoda: Caenogastropoda; Pulmonata). Archiv für Molluskenkunde 139 (1): 71-141. https://doi.org/10.1127/arch.moll/1869-0963/139/071-141

Fischer-Piette E., Blanc C.P., Blanc F. \& Salvat F. 1993. Gasteropodes terrestres prosobranches. Faune de Madagascar 80: 1-281. 
COLE M.L., Revision of cyclophorid snails Chondrocyclus s.l.

Fontanilla I.K., Naggs F. \& Wade C.M. 2017. Molecular phylogeny of the Achatinoidea (Mollusca: Gastropoda). Molecular Phylogenetics and Evolution 114: 382-385.

https://doi.org/10.1016/j.ympev.2017.06.014

Foon J.K. \& Liew T.-S. 2017. A review of the land snail genus Alycaeus (Gastropoda, Alycaeidae) in Peninsular Malaysia. ZooKeys 692: 1-81. https://doi.org/10.3897/zookeys.692.14706

Geldenhuys C.J. 1997. Composition and biogeography of forest patches on the inland mountains of the southern Cape. Bothalia 27(1): 57-74.

Gouws G., Matthee C.A. \& Stewart B.A. 2010. A multiple data set phylogeny for the endemic South African freshwater phreatoicidean isopod genus Mesamphisopus: Taxonomic and biogeographic implications. Molecular Phylogenetics and Evolution 55(2): 541-551.

https://doi.org/10.1016/j.ympev.2010.01.017

Griswold C.E. 1985. A revision of the African spiders of the family Microstigmatidae (Araneae: Mygalomorphae). Annals of the Natal Museum 27: 1-37.

Hamer M.L. \& Slotow R. 2002. Conservation application of existing data for South African millipedes (Diplopoda). African Entomology 10 (1): 29-42.

Harl J., Haring E., Asami T., Sittenthaler M., Sattmann H. \& Páll-Gergely B. 2017. Molecular systematics of the land snail family Orculidae reveal paraphyly and deep splits within the clade Orthurethra (Gastropoda: Pulmonata). Zoological Journal of the Linnean Society 181: 778-794.

https://doi.org/10.1093/zoolinnean/zlx022

Herbert D.G. 1997. The terrestrial slugs of Kwazulu-Natal: diversity, biogeography and conservation (Mollusca: Pulmonata). Annals of the Natal Museum 38: 197-239.

Herbert D.G. 2002. Gulella salpinx sp. n. a new, critically endangered, holoendemic species from the limestone deposits of the Marble Delta, KwaZulu-Natal, South Africa (Mollusca: Gastropoda: Streptaxidae). African Invertebrates 43: 125-138.

Herbert D.G. 2006. Rediscovery of the type species of Euonyma (Subulinidae) and observations on South African species of Gulella (Streptaxidae), with description of two new species (Gastropoda:Eupulmonata). Journal of Natural History 40 (17-18): 1063-1081. https://doi.org/10.1080/00222930600845218

Herbert D.G. 2007. Revision of the genus Prestonella (Mollusca: Gastropoda: Orthalicoidea: Bulimulidae s. l.), a distinctive component of the African land snail fauna. African Invertebrates 48: 1-19.

Herbert D.G. 2016. New narrow-range endemic land snails from the sky islands of northern South Africa (Gastropoda : Streptaxidae and Urocyclidae). European Journal of Taxonomy 236: 1-29.

https://doi.org/10.5852/ejt.2016.236

Herbert D.G. 2017. A new genus and eight new species of tail-wagger snails from eastern South Africa, with a key to genera within Sheldonia s. l. (Gastropoda: Urocyclidae). European Journal of Taxonomy 309: 1-50. https://doi.org/10.5852/ejt.2017.309

Herbert D. \& Kilburn D. 2004. Field Guide to the Land Snails and Slugs of Eastern South Africa. Natal Museum, Pietermaritzburg.

Herbert D.G. \& Mitchell A. 2009. Phylogenetic relationships of the enigmatic land snail genus Prestonella: The missing African element in the Gondwanan superfamily Orthalicoidea (Mollusca: Stylommatophora). Biological Journal of the Linnean Society 96 (1): 203-221. https://doi.org/10.1111/j.1095-8312.2008.01109.x 
Herbert D.G. \& Moussalli A. 2010. Revision of the larger cannibal snails Natalina s. 1. of southern AfricaNatalina s.s., Afrorhytida and Capitina (Mollusca: Gastropoda: Rhytididae). African Invertebrates 51 (1): 1-132. https://doi.org/10.5733/afin.051.0101

Herbert D.G. \& Moussalli A. 2016. Revision of the dwarf cannibal snails (Nata s.l.) of southern Africa Nata s.s. and Natella (Mollusca: Gastropoda: Rhytididae), with description of three new species. Zootaxa 4094: 1-67. https://doi.org/10.11646/zootaxa.4094.1.1

Hoare D.B., Mucina L., Rutherford M.C., Vlok J.H.J., Euston-Brown D.I.W., Palmer A.R., Powrie L.W., Lechmere-Oertel R.G., Procheş, Ş.M., Dold A.P. \& Ward R.A. 2006. Albany Thicket biome. In: Mucina L. \& Rutherford M.C. (eds) The Vegetation of South Africa, Lesotho and Swaziland. Strelitzia 19: 540-567. South African National Biodiversity Institute, Pretoria.

Huber B.A. 2003. Southern African pholcid spiders: revision and cladistic analysis of Quamtana gen. nov. and Spermophora Hentz (Araneae: Pholcidae), with notes on male-female covariation. Zoological Journal of the Linnean Society 139 (4): 477-527. https://doi.org/10.1046/j.0024-4082.2003.00082.x

Hughes M., Möller D., Bellstedt D.U., Edwards T.J. \& De Villiers M. 2005. Refugia, dispersal and divergence in a forest archipelago: a study of Streptocarpus in eastern South Africa. Molecular Ecology 14: 4415-4426. https://doi.org/10.1111/j.1365-294X.2005.02756.x

Kobelt W. 1902. Cyclophoridae. Das Tierreich 16 (I-XXXIX): 1-662. https://doi.org/10.5962/bhl.title.1227

Lee Y.-C., Lue K.-Y. \& Wu W.-L. 2008a. A molecular phylogenetic investigation of Cyathopoma (Prosobranchia: Cyclophoridae) in East Asia. Zoological Studies 47 (5): 591-604.

Lee Y.-C., Lue K.-Y. \& Wu W.-L. 2008b. Molecular evidence for a polyphyletic genus Japonia (Architaenioglossa: Cyclophoridae) and with the description of a new genus and two new species. Zootaxa 1792: 22-38.

Liew T.-S., Vermeulen J.J., Marzuki M.E. \& Schilthuizen M. 2014. A cybertaxonomic revision of the micro-landsnail genus Plectostoma Adam (Mollusca, Caenogastropoda, Diplommatinidae), from Peninsular Malaysia, Sumatra and Indochina. ZooKeys 393: 1-107.

https://doi.org/10.3897/zookeys.393.6717

Linder H.P. 2003. The radiation of the Cape flora, southern Africa. Biological Reviews 78 (4): 597-638. Available from http://www.ncbi.nlm.nih.gov/pubmed/14700393 [accessed 19 Sep. 2019].

Marshall B.A. \& Barker G.M. 2007. A revision of New Zealand landsnails of the genus Cytora Kobelt \& Möllendorff, 1897 (Mollusca: Gastropoda: Pupinidae). Tuhinga 18: 49-113.

McDonald D.E. \& Daniels S.R. 2012. Phylogeography of the Cape velvet worm (Onychophora: Peripatopsis capensis) reveals the impact of Pliocene Pleistocene climatic oscillations on Afromontane forest in the Western Cape, South Africa. Journal of Evolutionary Biology 25: 824-835. https://doi.org/10.1111/j.1420-9101.2012.02482.x

McDonald D.E., Ruhberg H. \& Daniels S.R. 2012. Two new Peripatopsis species (Onychophora: Peripatopsidae) from Western Cape province, South Africa. Zootaxa 3380: 55-68.

https://doi.org/10.11646/zootaxa.3380.1.4

McGeoch M.A., Sithole H., Samways M., Simaika J.P., Pryke J.S., Picker M., Uys C., Armstrong A.J., Dippenaar-Schoeman A.S., Engelbrecht I.A. \& Hamer M. 2011. Conservation and monitoring on invertebrates in terrestrial protected areas. Koedoe 53 (2): Art. \#1000.

https://doi.org/10.4102/koedoe.v53i2.1000 
COLE M.L., Revision of cyclophorid snails Chondrocyclus s.l.

Melvill J.C. \& Ponsonby J.H. 1898. Descriptions of nine new species of terrestrial Mollusca from South Africa. Annals and Magazine of Natural History Series $72: 125-130$.

https://doi.org/10.1080/00222939808678025

Melvill J.C. \& Ponsonby J.H. 1899. Further contribution towards a check-list of the non-marine molluscan fauna of South Africa, with descriptions of fourteen new species. Annals and Magazine of Natural History Series 7 4: 192-200. https://doi.org/10.1080/00222939908678183

Melvill J.C. \& Ponsonby J.H. 1903. Descriptions of thirty-one terrestrial and fluviatile Mollusca from South Africa. Annals and Magazine of Natural History Series 7 12: 595-609.

https://doi.org/10.1080/00222930309487040

MolluscaBase. 2019. Accessed through: World Register of Marine Species.

Available from http://www.marinespecies.org/aphia.php?p=taxdetails\&id=995565 [accessed 26 Apr. 2019].

Morton J.E. 1952. A preliminary study of the land operculate Murdochia pallidum (Cyclophoridae, Mesogastropoda). Transactions of the Royal Society of New Zealand 80: 69-79.

Moussalli A. \& Herbert D.G. 2016. Deep molecular divergence and exceptional morphological stasis in dwarf cannibal snails Nata sensu lato Watson, 1934 (Rhytididae) of southern Africa. Molecular Phylogenetics and Evolution 95: 100-115. https://doi.org/10.1016/j.ympev.2015.11.003

Moussalli A., Herbert D.G. \& Stuart-Fox D. 2009. A phylogeny of the cannibal snails of southern Africa, genus Natalina sensu lato (Pulmonata: Rhytididae): assessing concordance between morphology and molecular data. Molecular Phylogenetics and Evolution 52: 167-182.

https://doi.org/10.1016/j.ympev.2009.02.018

Mucina L. \& Geldenhuys C.J. 2006. Afrotemperate, subtropical and azonal forests. In: Mucina L. \& Rutherford M.C. (eds) The Vegetation of South Africa, Lesotho and Swaziland. Strelitzia 19: 585-614. South African National Biodiversity Institute, Pretoria.

Mucina L. \& Rutherford M.C. (eds) 2006. The Vegetation of South Africa, Lesotho and Swaziland. Strelitzia 19, South African National Biodiversity Institute, Pretoria.

Mucina L., Adams J.B., Knevel I.C., Rutherford M.C., Powrie L.W., Bolton J.J., van der Merwe J.H., Anderson R.J., Bornman T.G., le Roux A. \& Janssen J.A.M. 2006. Coastal vegetation of South Africa. In: Mucina L. \& Rutherford M.C. (eds) The Vegetation of South Africa, Lesotho and Swaziland. Strelitzia 19: 658-696. South African National Biodiversity Institute, Pretoria.

Mucina L., Pienaar E., Van Niekerk A. \& Lötter M.C. 2007. Habitat-level Classification of the Albany Coastal, Pondoland Scarp and Eastern Scarp forests. University of Stellenbosch, Matieland.

Myburgh A.M. \& Daniels S.R. 2015. Exploring the impact of habitat size on phylogeographic patterning in the Overberg velvet worm Peripatopsis overbergiensis (Onychophora: Peripatopsidae). Journal of Heredity 106: 296-305. https://doi.org/10.1093/jhered/esv014

Nantarat N., Sutcharit C., Tongkerd P., Ablett J., Naggs F. \& Panha S. 2014a. An annotated catalogue of type specimens of the land snail genus Cyclophorus Monfort, 1810 (Caenogastropoda, Cyclophoridae) in the Natural History Museum, London. ZooKeys 411: 1-56. https://doi.org/10.3897/zookeys.411.7258

Nantarat N., Wade C.M., Jeratthitikul E., Sutcharit C. \& Panha S. 2014b. Molecular evidence for cryptic speciation in the Cyclophorus fulguratus (Pfeiffer, 1854) species complex (Caenogastropoda: Cyclophoridae) with description of new species. PLOS ONE 9 (10): 1-15.

https://doi.org/10.1371/journal.pone.0109785

Neubert E. \& Bouchet P. 2015. The Diplommatinidae of Fiji - a hotspot of Pacific land snail biodiversity (Caenogastropoda, Cyclophoroidea). ZooKeys 487: 1-85. https://doi.org/10.3897/zookeys.487.8463 
Páll-Gergely B., Fehér Z., Hunyadi A. \& Asami T. 2015. Revision of the genus Pseudopomatias and its relatives (Gastropoda: Cyclophoroidea: Pupinidae). Zootaxa 3937 (1): 1-49.

https://doi.org/10.11646/zootaxa.3937.1.1

Páll-Gergely B., Hunyadi A. \& Asami T. 2017a. A new diplommatinid genus and two new species from the Philippines (Gastropoda, Caenogastropoda, Cyclophoroidea). ZooKeys 678: 1-10.

https://doi.org/10.3897/zookeys.678.13059

Páll-Gergely B., Hunyadi A., Sang D., Naggs F. \& Asami T. 2017b. Revision of the Alycaeidae of China, Laos and Vietnam (Gastropoda: Cyclophoroidea) I: The genera Dicharax and Metalycaeus. Zootaxa 4331: 1-124. https://doi.org/10.11646/zootaxa.4331.1.1

Partridge T.C. 1993. Warming phases in Southern Africa during the last 150,000 years: an overview. Palaeogeography, Palaeoclimatology and Palaeoecology 101: 237-244.

https://doi.org/10.1016/0031-0182(93)90016-C

Partridge T.C., Scott L. \& Hamilton J.E. 1999. Synthetic reconstructions of southern African environments during the Last Glacial Maximum (21-18 kyr) and the Holocene Altithermal (8-6 kyr). Quaternary International 57-58: 207-214. https://doi.org/10.1016/S1040-6182(98)00061-5

Pfeiffer L. 1855. Descriptions of a new genus and twenty-three new species of Pneumonopoma, from the collection of H. Cuming, Esq. Proceedings of the Zoological Society of London 23: 101-108.

Pfenninger M., Hrabáková M., Steinke D. \& Dèpraz A. 2005. Why do snails have hairs? A Bayesian inference of character evolution. BMC Evolutionary Biology 5 (59): 1-11.

https://doi.org/10.1186/1471-2148-5-59

Phung C-C., Heng P.-S. \& Liew T.-S. 2017. Land snails of Leptopoma Pfeiffer, 1847 in Sabah, Northern Borneo (Caenogastropoda: Cyclophoridae): an analysis of molecular phylogeny and geographical variations in shell form. PeerJ 5:e3981. https://doi.org/10.7717/peerj.3981

Potts A.J., Hedderson T.A., Franklin J. \& Cowling R.M. 2012. The Last Glacial Maximum distribution of South African subtropical thicket inferred from community distribution modelling. Journal of Biogeography 40 (2): 310-322. https://doi.org/10.1111/j.1365-2699.2012.02788.x

Price B.W., Barker N.P. \& Villet M.H. 2007. Patterns and processes underlying evolutionary significant units in the Platypleura stridula L. species complex (Hemiptera: Cicadidae) in the Cape Floristic Region, South Africa. Molecular Ecology 16 (12): 2574-2588.

https://doi.org/10.1111/j.1365-294X.2007.03328.x

Price B.W., Barker N.P. \& Villet M.H. 2010. A watershed study on genetic diversity: phylogenetic analysis of the Platypleura plumosa (Hemiptera: Cicadidae) complex reveals catchment-specific lineages. Molecular Phylogenetics and Evolution 54(2): 617-626. https://doi.org/10.1016/j.ympev.2009.10.011

Rebelo A.G., Boucher C., Helme N., Mucina L. \& Rutherford M.C. 2006. Fynbos biome. In: Mucina L. \& Rutherford M.C. (eds) The Vegetation of South Africa, Lesotho and Swaziland. Strelitzia 19: 52-219. South African National Biodiversity Institute, Pretoria.

Rowson B. \& Herbert D.G. 2016. The type species and circumscription of the species-rich Afrotropical snail genus Gulella L. Pfeiffer 1856, based on anatomical and mtDNA data (Mollusca: Eupulmonata: Streptaxidae). Archiv für Molluskenkunde 145: 69-84.

https://doi.org/10.1127/arch.moll/1869-0963/145/069-084

Rowson B., Tattersfield P. \& Symondson W.O.C. 2010a. Phylogeny and biogeography of tropical carnivorous land-snails (Pulmonata: Streptaxoidea) with particular reference to East Africa and the Indian Ocean. Zoologica Scripta 40: 85-98. https://doi.org/10.1111/j.1463-6409.2010.00456.x 
COLE M.L., Revision of cyclophorid snails Chondrocyclus s.l.

Rowson B., Warren B.H. \& Ngereza C.F. 2010b. Terrestrial molluscs of Pemba Island, Zanzibar, Tanzania, and its status as an "oceanic" island. ZooKeys 70: 1-39. https://doi.org/10.3897/zookeys.70.762

Ruhberg H. \& Daniels S.R. 2013. Morphological assessment supports the recognition of four novel species in the widely distributed velvet worm Peripatopsis moseleyi sensu lato (Onychophora: Peripatopsidae). Invertebrate Systematics 27: 131-145.

https://doi.org/10.1071/IS12069

Rundell R.J. 2008. Cryptic diversity, molecular phylogeny and biogeography of the rock- and leaf litterdwelling land snails of Belau (Republic of Palau, Oceania). Philosophical Transactions of the Royal Society B: Biological Sciences 363 (1508): 3401-3412. https://doi.org/10.1098/rstb.2008.0110

Scott L., Anderson H.M. \& Anderson J.M.1997. Vegetation history. In: Cowling R.M., Richardson D.M. \& Pierce S.M. (eds) Vegetation of southern Africa: 62-84. Cambridge University Press, Cambridge.

Sirgel W.F. 1985. A new subfamily of Arionidae (Mollusca, Pulmonata). Annals of the Natal Museum 26 (2): 471-487.

Stuckenberg B.R. 1962. The distribution of the montane palaeogenic element in the South African invertebrate fauna. Annals of the Cape Provincial Museums 2: 190-205.

Sturany R. 1898. Cyclotus isipingoensis n. sp. Anzeiger der Akademie der Wissenschaften in Wien 35: 161.

Sutcharit C., Tongkerd P. \& Panha S. 2014. The land snail genus Pterocyclos Benson, 1832 (Caenogastropoda: Cyclophoridae) from Thailand and Peninsular Malaysia, with descriptions of two new species. The Raffles Bulletin of Zoology 62: 330-338.

Tilbury C. \& Tolley K. 2009. A new species of dwarf chameleon (Sauria; Chamaeleonidae, Bradypodion Fitzinger) from KwaZulu Natal South Africa with notes on recent climatic shifts and their influence on speciation in the genus. Zootaxa 2226 (1): 43-57. https://doi.org/10.11646/zootaxa.2226.1.4

Tolley K.A., Burger M., Turner A.A. \& Matthee C.A. 2006. Biogeographic patterns and phylogeography of dwarf chameleons (Bradypodion) in an African biodiversity hotspot. Molecular Ecology 15: 781-793. https://doi.org/10.1111/j.1365-294X.2006.02836.x

Tolley K.A., Chase B.M. \& Forest F.F. 2008. Speciation and radiations track climate transitions since the Miocene Climatic Optimum: a case study of southern African chameleons. Journal of Biogeography 35 (8): 1402-1414. https://doi.org/10.1111/j.1365-2699.2008.01889.x

van Wyk A.E. \& Smith G.F. 2001. Regions of Floristic Endemism in Southern Africa. Umdaus Press, Hatfield.

von Maltitz G., Mucina L., Geldenhuys C., Lawes M., Eeley H., Adie H., Vink D., Fleming G. \& Bailey C. 2003. Classification System for South African Indigenous Forests. CSIR, Pretoria.

Von Oheimb P.V., von Oheimb K.C.M., Hirano T., van Do T., van Luong H., Ablett J., van Pham S. \& Naggs F. 2018. Competition matters: Determining the drivers of land snail community assembly among limestone karst areas in northern Vietnam. Ecology and Evolution 8: 4136-4149.

https://doi.org/10.1002/ece3.3984

Webster N.B., Van Dooren T.J.M. \& Schilthuizen M. 2012. Phylogenetic reconstruction and shell evolution of the Diplommatinidae (Gastropoda: Caenogastropoda). Molecular Phylogenetics and Evolution 63 (3): 625-638. https://doi.org/10.1016/j.ympev.2012.02.004

Weimarck H. 1941. Phytogeographical Groups, Centres and Intervals Within the Cape Flora. Lund, Leipzig. 
Yamazaki K., Yamazaki M. \& Ueshima R. 2013. Systematic review of diplommatinid land snails (Caenogastropoda, Diplommatinidae) endemic to the Palau Islands. (1) Generic classification and revision of Hungerfordia species with highly developed axial ribs. Zootaxa 3743 (1): 1-71. https://doi.org/10.11646/zootaxa.3743.1.1

Yamakazi K., Yamakazi M. \& Ueshima R. 2015a. Systematic review of diplommatinid land snails (Caenogastropoda, Diplommatinidae) endemic to the Palau Islands. (2) Taxonomic revision of Hungerfordia species with low axial ribs. Zootaxa 3976: 1-89. https://doi.org/10.11646/zootaxa.3976.1.1

Yamazaki K., Yamazaki M., Rundell R.J. \& Ueshima R. 2015b. Systematic review of diplommatinid land snails (Caenogastropoda, Diplommatinidae) endemic to the Palau Islands. (3) Description of eight new species and two new subspecies of Hungerfordia. Zootaxa 4057 (4): 511-538. https://doi.org/10.11646/zootaxa.4057.4.3

Manuscript received: 18 February 2019

Manuscript accepted: 9 June 2019

Published on: 22 October 2019

Topic editor: Rudy Jocqué

Section editor: Thierry Backeljau

Desk editor: Kristiaan Hoedemakers

Printed versions of all papers are also deposited in the libraries of the institutes that are members of the EJT consortium: Muséum national d'histoire naturelle, Paris, France; Meise Botanic Garden, Belgium; Royal Museum for Central Africa, Tervuren, Belgium; Royal Belgian Institute of Natural Sciences, Brussels, Belgium; Natural History Museum of Denmark, Copenhagen, Denmark; Naturalis Biodiversity Center, Leiden, the Netherlands; Museo Nacional de Ciencias Naturales-CSIC, Madrid, Spain; Real Jardín Botánico de Madrid CSIC, Spain; Zoological Research Museum Alexander Koenig, Bonn, Germany; National Museum, Prague, Czech Republic. 